UNIVERSIDADE DE SÃO PAULO

ESCOLA DE ARTES, CIÊNCIAS E HUMANIDADES

RAYANA SANTIAGO DE QUEIROZ

Pesquisa e criação: desenvolvimento de coleção de fios de fibras de paina 


\section{Pesquisa e criação: desenvolvimento de coleção de fios de fibras de paina}

Dissertação apresentada à Escola de Artes, Ciências e Humanidades da Universidade de São Paulo para obtenção do título de Mestre em Ciências do Programa de Pós-graduação Têxtil e Moda.

Versão corrigida contendo alterações solicitadas pela comissão julgadora em 16 de outubro de 2013. A versão original encontra-se em acervo reservado na Biblioteca da EACH/USP e na Biblioteca Digital de Teses e Dissertações da USP (BDTD), de acordo com a Resolução CoPGr 6018, de 13 de outubro de 2011.

Linha de pesquisa: Projeto de têxtil e moda

Orientadora: Prof ${ }^{\mathrm{a} .}$ Dra. Suzana Helena de Avelar Gomes 
Autorizo a reprodução e divulgação total ou parcial deste trabalho, por qualquer meio convencional ou eletrônico, para fins de estudo e pesquisa, desde que citada a fonte.

\author{
CATALOGAÇÃO-NA-PUBLICAÇÃO \\ Universidade de São Paulo \\ Escola de Artes, Ciências e Humanidades \\ Biblioteca
}

Queiroz, Rayana Santiago de

Pesquisa e criação : desenvolvimento de coleção de fios de fibras de paina / Rayana Santiago de Queiroz; orientadora, Suzana Helena de Avelar Gomes. - São Paulo, 2014

$107 \mathrm{f.}$ : il.

Dissertação (Mestrado em Ciências) - Programa de PósGraduação em Têxtil e Moda, Escola de Artes, Ciências e Humanidades, Universidade de São Paulo, em 2013 Versão corrigida

1. Fibras têxteis. 2. Tecnologia têxtil. 3. Fibras naturais. 4. Fios (Indústria têxtil). 5. Moda. I. Gomes, Suzana Helena de Avelar, orient. II. Título 
Nome: QUEIROZ, Rayana Santiago

Título: Pesquisa e criação: desenvolvimento de coleção de fios de fibras de paina

Dissertação apresentada ao Programa de Pós-graduação em Têxtil e Moda da Escola de Artes, Ciências e Humanidades da Universidade de São Paulo para obtenção do título de Mestre em Ciências.

Aprovado em: 16.10 .2013

Banca examinadora

Professora D ${ }^{\text {ra }}$ Suzana Helena de Avelar Gomes

Professora $D^{\text {ra }}$ Rita de Morais Andrade

Professora D ${ }^{\text {ra }}$ Cláudia Regina Garcia Vicentini
Instituição: Universidade de São Paulo Escola de Artes Ciências e Humanidades

Instituição: Universidade Federal de Goiás - Faculdade de Artes Visuais

Instituição: Universidade de São Paulo Escola de Artes Ciências e Humanidades 
Ao rico conhecimento popular e tradicional brasileiro e a todos aqueles que o detêm, dos quais nos inspiraram a perspectiva de transformação do mundo num espaço mais igualitário, acolhedor e belo para maior quantidade possível de pessoas. 


\section{AGRADECIMENTOS}

A trajetória de pós-graduação certamente não é uma das experiências mais fáceis: os desafios impostos pela própria pesquisa, o tempo que sempre parece insuficiente, o cansaço físico e mental, a solidão... Isso tudo exigiu um sólido amadurecimento pessoal e profissional, grande disposição para auto-superação e resiliência. A realização desta pesquisa e a conquista destes atributos foram possíveis graças a generosa contribuição de pessoas que estiveram ao meu lado, das quais devo minha imensa gratidão.

Primeiramente, agradeço àqueles que sempre apostaram e confiaram nos meus sonhos e que trago comigo parte de suas essências e ideais: à minha mãe sou grata por me provocar a busca constante pela verdadeira essência das coisas, por me ensinar a cultivar o belo nas coisas simples, por todo apoio e orientação profissional e emocional, que permitiram minha "reconciliação" com a pesquisa no momento mais difícil. Ao meu pai agradeço por me ensinar a ver a vida com fé e serenidade, pelo zelo e afeto incondicionais.

Agradeço também àquelas pessoas que estiveram presentes neste momento da minha vida, tornando-o mais fácil e agradável: ao meu parceiro, Leonardo, sou grata pelo companheirismo, zelo, apoio emocional e incentivo nestes anos da pós-graduação. E à sua família sou imensamente grata pela acolhida. Às amigas Caroline, Lívia e Malu agradeço pelos curtos momentos de descontração, pelas longas conversas, pela compreensão e empatia nos momentos delicados.

Obrigada à orientadora Profa. Suzana, pelo respeito e compreensão às minhas inquietações, por nortear os caminhos desta pesquisa de maneira respeitosa, e pelo apoio na superação dos desafios da pesquisa.

Agradeço profundamente àqueles que com simples, mas indispensáveis, contribuições tornaram este trabalho possível: ao professor Donizeti Speranza, pela orientação técnica e participação no desenvolvimento dos fios. Ao Sr. Wladimir Corrêa, pela ajuda na coleta das fibras de paina. Ao meu tio, Carlos Nobeschi, por fornecer as fibras de lã. 


\section{Obrigada}

Ao Instituto de Pesquisa Tecnológica do Estado de São Paulo por conceder-me o tempo para cursar a pós-graduação, em especial ao Laboratório de Tecnologia Têxtil, pela disponibilização da sua infraestrutura para realização dos experimentos.

À Escola de Artes, Ciências e Humanidades da Universidade de São Paulo pela oportunidade concedida.

À colega Regina Camboim, com quem dividi essa trajetória, pela amizade e pela parceria no desenvolvimento de trabalhos conjuntos.

À Gabriele Paula de Oliveira e à Karina Oru Oshio, colegas com os quais pude contar para dividir as responsabilidades profissionais durante os períodos de ausência do trabalho. Também ao colega Fernando Soares de Lima, pelas pequenas, porém relevantes, contribuições técnicas e pelas longas conversas sobre as "aflições de um pós-graduando".

Aos professores que compartilharam os seus conhecimentos nas disciplinas, de forma especial ao Prof. Dr. Antonio Takao. 
"Os conceitos são as lentes através das quais a mente enxerga a realidade. Se essas lentes estiverem sujas e velhas, certamente você enxergará uma realidade distorcida e acreditará que ela é assim." 


\section{RESUMO}

\section{QUEIROZ, R. S. Pesquisa e criação: desenvolvimento de coleção de fios de fibras de paina.}

2014. 99 f. Dissertação (Mestrado em Ciências) - Escola de Artes, Ciências e Humanidades, Universidade de São Paulo; São Paulo, 2013. Versão corrigida.

Das lógicas vigentes de produção e consumo mais recorrentes no sistema da moda, emergem problemáticas ambientais e sociais de escala mundial. Ao longo da sua evolução, a produção têxtil, uma das atividades humanas mais antigas e elementares, tornou-se uma importante responsável pelo consumo em grande escala e uso indevido de recursos naturais e, associada aos valores de consumo da sociedade urbano-industrial, a sazonalidade da moda é mais um agravante. Fruto de uma visão de mundo fragmentada, intrínseca ao paradigma moderno, o design têxtil e de moda, assim como outras áreas do conhecimento, se desenvolveram orientados a sustentar um padrão de desenvolvimento econômico e tecnológico compatíveis com estas lógicas, de forma que no Brasil, importantes saberes sobre processos tecnológicos e o uso de matérias-primas inerentes a nossa cultura popular foram levados a um processo de desuso e esquecimento. Saberes estes intimamente associados à biodiversidade e tidos como de extrema importância dentro das políticas nacionais e internacionais de desenvolvimento ambiental e social. Neste contexto, este trabalho se desenvolveu com o objetivo de propor uma coleção de fios, produzidos a partir de fibras de paina, da espécie nativa Chorisia speciosa, e de técnicas têxteis artesanais, associando à criação as pesquisas teórica e experimental. 0 método que delineamos para o desenvolvimento da coleção de fios abrange: i) pesquisa teórico-conceitual, em que foram levantados os principais conhecimentos sobre as matérias primas e técnicas no âmbito da cultura têxtil popular brasileira e as principais tendências de moda e consumo no Brasil e no mundo; ii) pesquisa técnico-experimental, fase da pesquisa em que foi testada a viabilidade técnica de transformar as fibras de paina e diferentes misturas destas com fibras de algodão e lã em um fio, bem como o seu tingimento, utilizando as técnicas artesanais pesquisadas na etapa anterior; iii) desenvolvimento da coleção de fios propriamente dita. A partir dos dados obtidos na pesquisa, foi identificado que o vasto conhecimento popular a cerca das técnicas têxteis demonstra imenso potencial ao incorporá-lo no processo criativo têxtil. Além disso, a pesquisa técnico-experimental apontou a viabilidade de fiação da paina com misturas de algodão e lã, bem como o seu tingimento natural. Por meio deste trabalho foi possível então ratificar a importância e potencial de aliar a pesquisa científica à criação de moda tanto para o desenvolvimento de um novo material, como na proposição de formas distintas de produção e consumo de moda. As tendências de moda pesquisadas demonstraram que uma parcela da sociedade vive na atualidade uma intensa e acelerada redefinição de conceitos, valores e estilo de vida que contrariam a configuração do mercado de moda e a lógica de consumo predominante inerente a este, e se projetam gradativamente em transformações nos comportamentos de consumo e consequentemente no mercado e economia. Assim, elas apenas reafirmam a valia da presente pesquisa para o mercado de moda e a propensão deste à aceitação de produtos como o que propusemos aqui.

Palavras chaves: Moda. Criação. Artesanato têxtil. Fibras naturais. Paina. 


\section{ABSTRACT}

\section{QUEIROZ, R. S. Research and design: development of yarns collection with kapok fibers.}

2014. 99 f. Thesis of Master (Master of Science) - Escola de Artes, Ciências e Humanidades Universidade de São Paulo; São Paulo, 2013. Corrected version.

Social and environmental issues have emerged in global scale from the prevailing logics of production and consumption recurrent in the fashion system. The textile production, one of the oldest elementary human activities, has become a major factor in large scale consumption and in the misuse of natural resources throughout its evolution. Another aggravating factor is the urban-industrial society consumption values and the seasonality of fashion. As a result of a fragmented worldview, intrinsic to the modern paradigm, the textile and fashion design - as well as other areas of knowledge - have been developed towards the sustainability of economic and technological development patterns compatible to these logics. In Brazil, important knowledge about technological processes and the use of raw materials, inherent in our popular culture, feel in disuse and oblivion. This knowledge is closely associated with biodiversity and taken with paramount importance for national and international environmental and social development policies. In this context, this work was developed aiming to propose a yarn collection produced with kapok fibers - from the native specie Chorisia speciosa - and textile craft techniques, linking creation to theoretical and experimental research. The outlined method for the development of the yarn collection includes: i) theoretical and conceptual research, in which we analyzed the main knowledge on raw materials and techniques in Brazilian popular textile culture and main fashion and consumption trends in Brazil and the world, ii) technical and experimental research, the phase in which we tested the technical feasibility of kapok fibers transformation and different mixtures of these fibers with cotton and wool on a yarn, as well as its dyeing, using the handmade techniques surveyed in the previous step, iii) development of yarn collection. From the data obtained in the research, we identified that the vast popular knowledge on technical textiles have immense potential to be incorporated in creative textile process. In addition, technical experimental research demonstrated the feasibility of kapok spinning with mixtures of cotton and wool, as well as its natural dyeing. Throughout the work, it was possible to confirm the potential importance of linking scientific research to fashion creation for both the development of new material and for proposing different forms of fashion production and consumption. Fashion trend research showed that part of the society is experiencing an intense and accelerated redefinition of concepts, values and lifestyle that contradicts the fashion market configuration and its consumer logic. Results of this process have gradually been projected as changes in consumer behavior, and consequently, in the market and the economy. Therefore, they reaffirm this research value for the fashion market and its propensity to accept the proposed products.

Key words: Fashion. Design. Textile handcrafts. Natural fibers. Kapok. 


\section{LISTA DE ILUSTRAÇÕES}

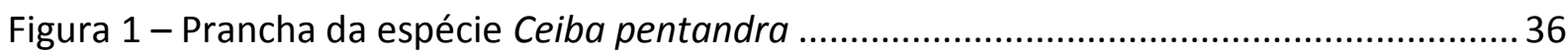

Figura 2 - Árvore da espécie Ceiba pentandra .................................................................. 36

Figura 3 - Prancha da espécie Chorisia speciosa .................................................................... 37

Figura 4 - Fios compostos de uma mistura $85 \%$ algodão e 15\% paina da marca Sublime Yarns 38

Figura 5 - Etapas da fiação do algodão ............................................................................. 43

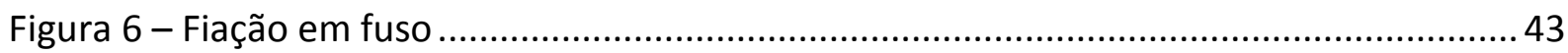

Figura 7 - Pastas de lã ou algodão produzidas após processo de cardação............................ 44

Figura 8 - Tipos de fios - a: "trochado" b: "papo e finirisco" c: "fantasiado" ......................... 46

Figura 9 - Tendências de estilo de vida observadas em revistas de estilo de vida ................. 56

Figura 10 - Tendências de estilo de vida observadas em weblogs de design ......................... 57

Figura 11 - Tendências de estilo de vida observadas em weblogs de design ......................... 58

Figura 12 - Tendências de cores, materiais e formas em objetos observadas em blogs de

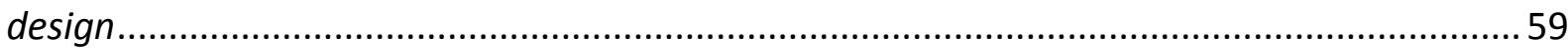

Figura 13 - Tendências de cores, materiais e formas em moda observadas em weblogs de

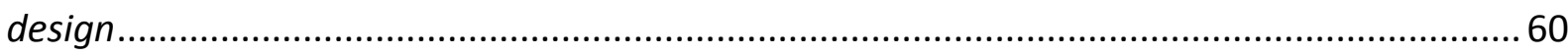

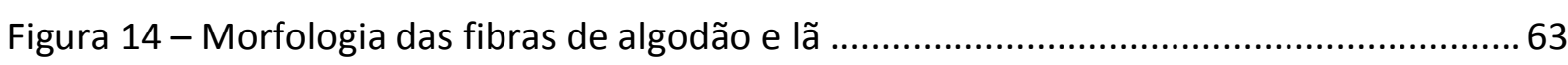

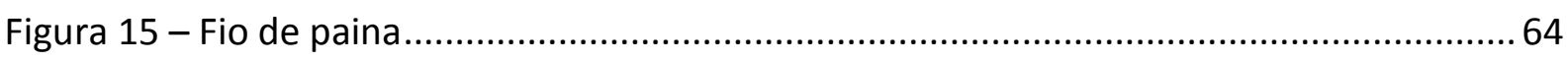

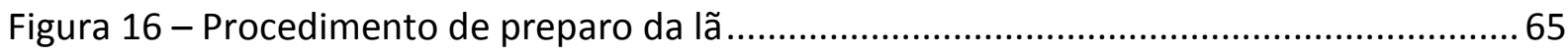

Figura 17 - Pastas de paina e lã produzidas na cardagem ...................................................66

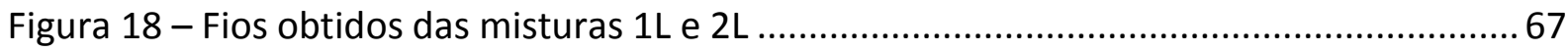

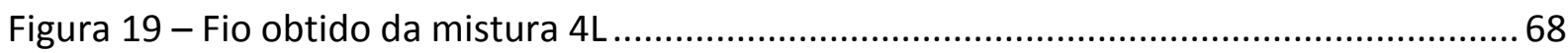

Figura 20 - Procedimento de preparo do algodão em manta ...............................................69

Figura 21 - Procedimento de preparo do algodão em fibra ..................................................69

Figura 22 - Pastas de paina e algodão em manta produzidas na cardagem .......................... 70

Figura 23 - Pastas de paina e algodão em fibra produzidas na cardagem ............................. 71

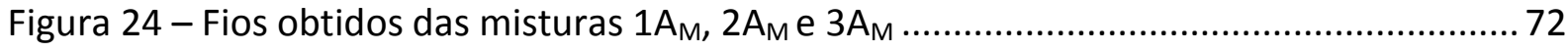

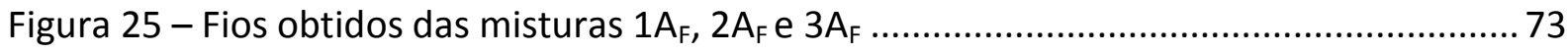

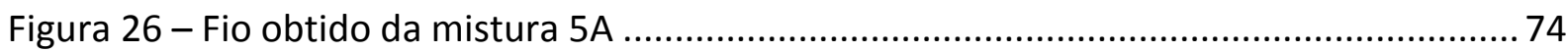

Figura 27 - Tecido-testemunha multifibra utilizado para controlar o tingimento ................... 76

Figura 28 - Receita de tingimento com o barbatimão ......................................................... 77

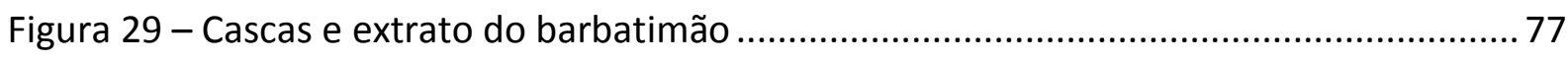

Figura 30 - Tingimento das fibras de paina com barbatimão ............................................. 78

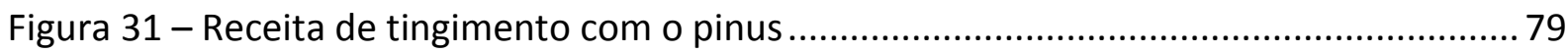




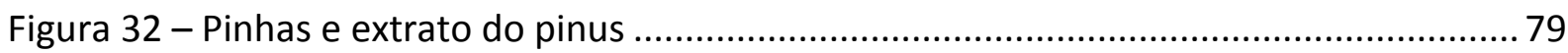

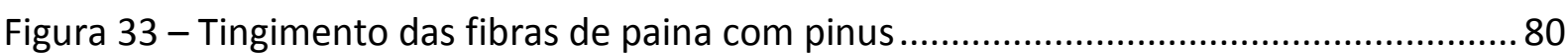

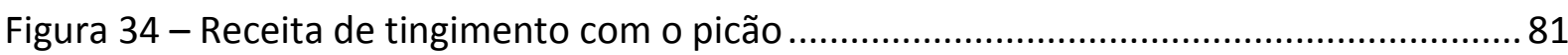

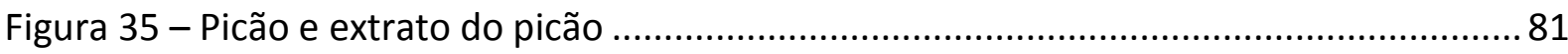

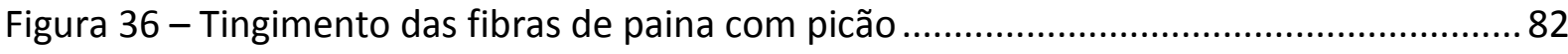

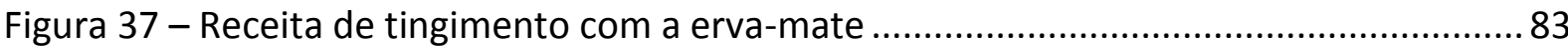

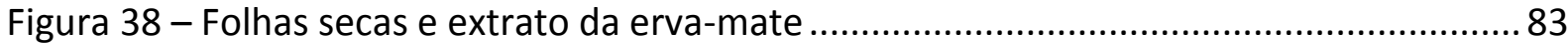

Figura 39 - Tingimento das fibras de paina com erva-mate ................................................ 84

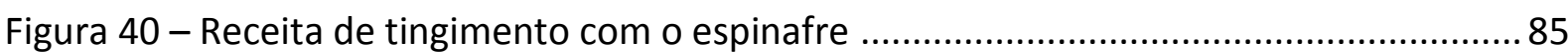

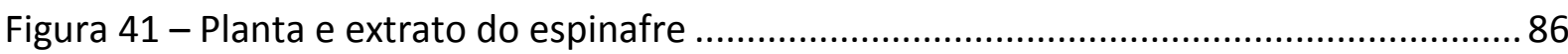

Figura 42 - Tingimento das fibras de paina com espinafre ............................................... 86

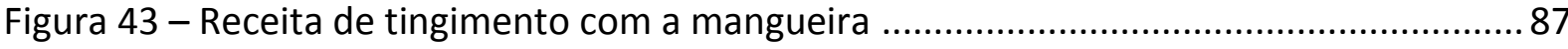

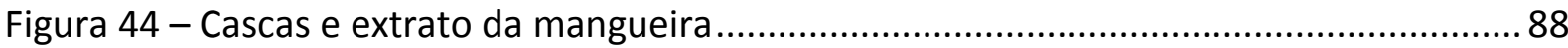

Figura 45 - Tingimento das fibras de paina com cascas da mangueira ..................................8 88

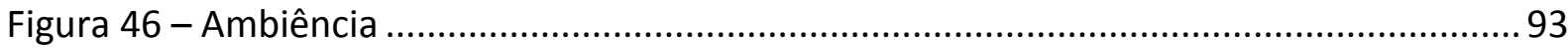

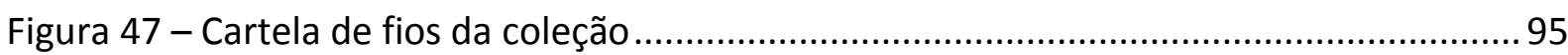

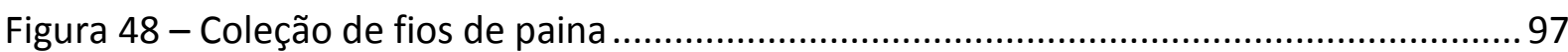




\section{LISTA DE TABELAS}

Tabela 1 - Plantas para preparo da cinza para decoada.......................................................... 48

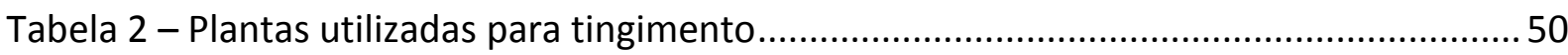

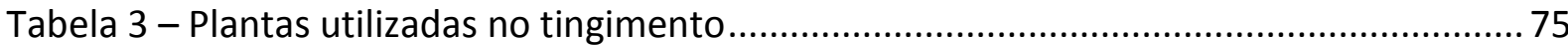




\section{SUMÁRIO}

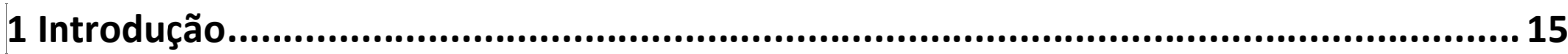

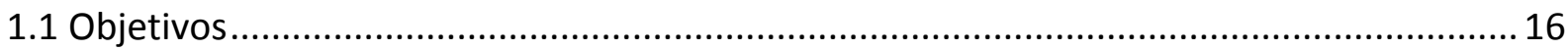

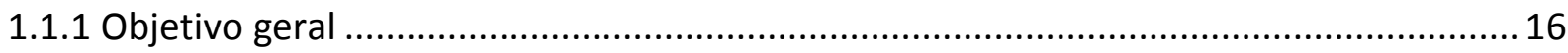

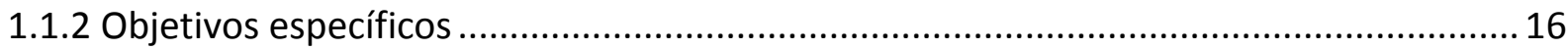

1.2 Referencial teórico metodológico e procedimentos de pesquisa ................................... 17

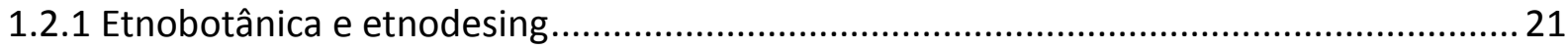

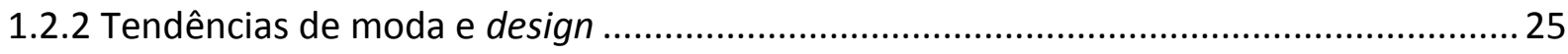

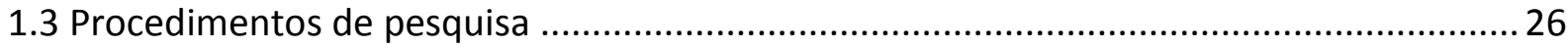

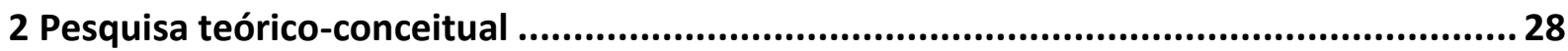

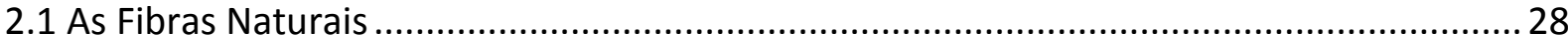

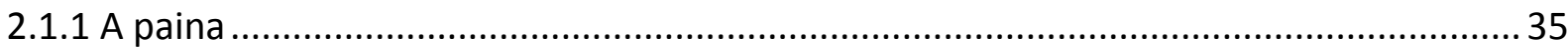

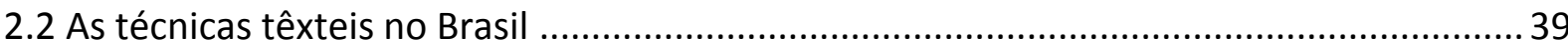

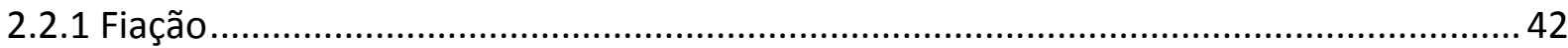

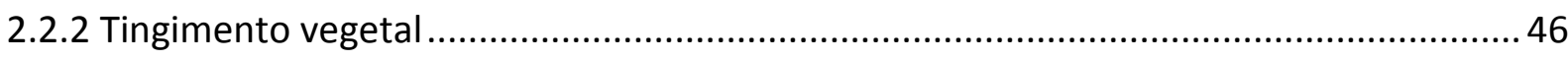

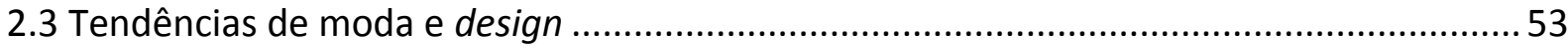

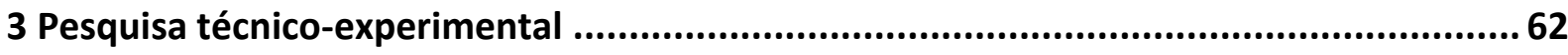

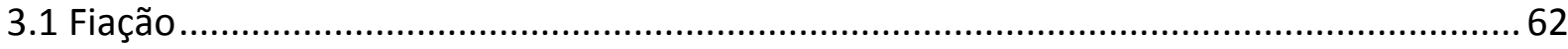

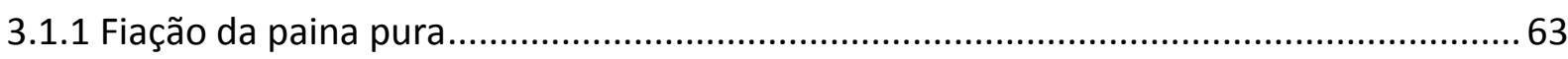

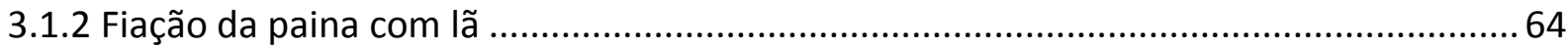

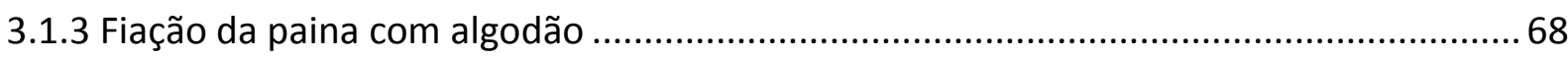

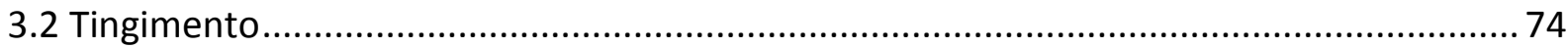

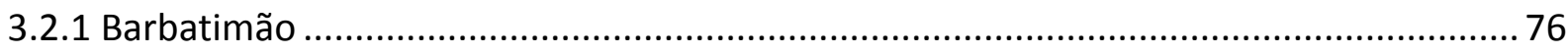

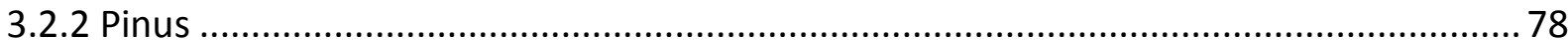

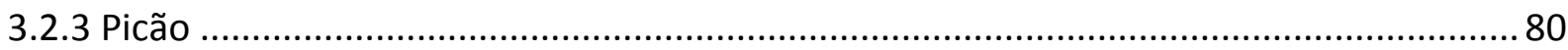

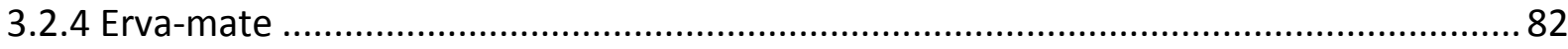

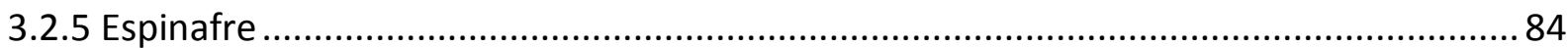

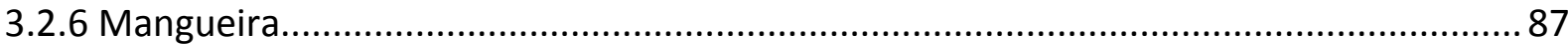

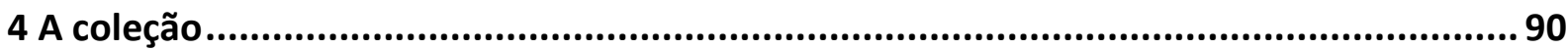

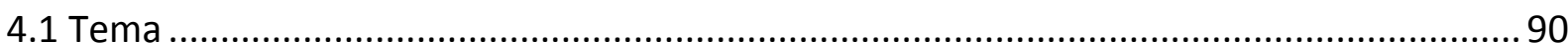




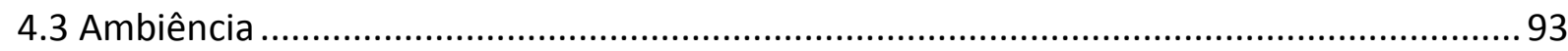

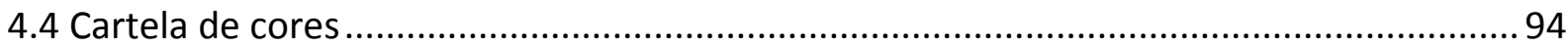

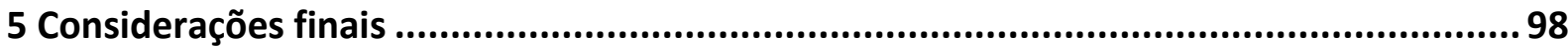

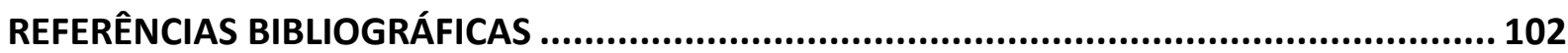

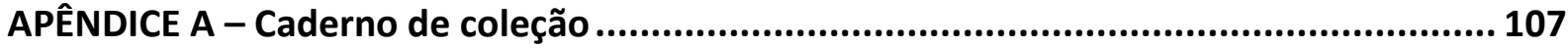




\section{Introdução}

As lógicas vigentes de produção e consumo mais recorrentes no sistema da moda, como ocorrem no mercado de vestuário na dinâmica de produção e venda do "fast fashion", vêm contribuído para o agravamento de problemáticas ambientais e socioculturais de escala mundial, como a exploração de trabalhadores, desperdício de recursos naturais (CLARK, 2008) e utilização indevida de materiais e processos. Uma das consequências negativas dessa dinâmica, pôde ser evidenciada por fatos recentes envolvendo marcas de grandes magazines. Como exemplo podemos citar o caso do programa A Liga, da TV Bandeirantes, que em 2011 denunciou mais de trinta oficinas fornecedoras da Zara (marca de maior referência da dinâmica fast fashion) com condições de trabalho irregulares: ambientes sem segurança e insalubres, mão de obra ilegal e isenta de direitos trabalhistas. Essas condições de trabalho viabilizam a redução dos custos de produção e consequentemente favorecem os lucros. Naturalmente, não apenas a mão de obra barata e qualificada é bastante para sustentar essa lógica, mas toda a cadeia de produção do vestuário, da produção de fibras à confecção dos artigos têxteis, é necessário atender requisitos para produzir mais no menor tempo e custo possível. Para isso é preciso fazer uso de matérias primas e recursos tecnológicos que possibilitem esse tipo de produção, sem muitas vezes se preocupar com a qualidade do produto, ou com questões sociais e ambientais associadas.

Nesse sentido, a indústria têxtil tornou-se uma importante responsável pelo consumo em grande escala e uso indevido de recursos naturais e, associada aos valores de consumo da sociedade urbano-industrial, a sazonalidade da moda é mais um agravante. Em consequência, o ritmo desenfreado de produção e consumo de moda - centrado na expansão das necessidades e organizado para um o consumo de massa, que sobrevive, como diz Lipovetsky (1994), sob a lei da obsolescência programada - tem impactado de forma negativa. A produção e o consumo de massa é um dos motivos de se atribuir tanta importância econômica às fibras manufaturadas (sintéticas e artificiais) e aos processos de produção em larga escala no mercado de vestuário. Essa lógica então, ao submeter os processos de criação e desenvolvimento de produtos a seu benefício, não apenas colabora com os prejuízos sociais e ambientais como também empobrece o design, ao desprezar uma ampla gama de tecnologias e recursos que eventualmente não atendam seus interesses. 
Como é colocado por Finkelsztejn (2005):

[...] os processos produtivos que geram desperdícios sociais, ambientais e econômicos apontam para a urgência, não apenas de uma nova configuração do fazer técnico e das atividades projetuais [...], mas principalmente de novas formas de conceber, produzir, consumir e pensar "conforto" e "valores" (FINKELSZTEJN, 2005, p 71).

Nesse contexto, a formação de uma crítica sobre o design têxtil aliado à tecnologia e a referências do Brasil, como suas técnicas têxteis populares e suas matérias primas, será o foco deste trabalho. Por meio do procedimento de pesquisa adotado, procuramos reforçar a importância em aliar a pesquisa teórica e experimental ao processo criativo, com o intuito de não apenas de gerar produtos e materiais inovadores, mas também buscando incorporar aos produtos novos valores de produção e consumo, fruto de um processo crítico de reflexão. Assim, como alternativa às lógicas de produção e consumo citadas no início deste capitulo, o trabalho que apresentamos aqui tem como objetivo principal o desenvolvimento de uma coleção de fios baseado na fusão entre as ferramentas da pesquisa científica e as ferramentas de criação de moda e na valorização de técnicas têxteis artesanais e matérias primas nativas (fibras de paina e corantes vegetais), demonstrando que tal aproximação é possível e que pode contribuir para a inovação no artesanato popular tradicional, bem como para novas abordagens de produção têxtil que levem em consideração os elementos sociais e tecnológicos no processo de criação.

\subsection{Objetivos}

\subsubsection{Objetivo geral}

Desenvolvimento de uma cartela de fios produzidos a partir de fibras de paina de espécie nativa do Brasil (Chorisia speciosa) e técnicas têxteis artesanais, agregando à criação as pesquisas teórica e experimental.

\subsubsection{Objetivos específicos}

- Realizar um levantamento de técnicas têxteis artesanais de fiação e tingimento utilizadas no Brasil;

- Identificar o conhecimento sobre o uso da paina e suas aplicabilidades;

- $\quad$ Experimentar, por meio das técnicas de fiação levantadas, a possibilidade de fiar as 
fibras de paina pura, e diferentes misturas desta com algodão e lã.

- Experimentar, por meio das técnicas de tingimento levantadas, a possibilidade de tingir a paina com corantes naturais.

- Incorporar no processo criativo tecnologias desenvolvidas a partir de técnicas têxteis estudadas.

- Desenvolver um conceito de coleção baseado na pesquisa teórica realizada e em prospecções de moda levantadas no bureaux Textile View Magazine, que norteará tanto a temática da coleção como a forma de produção dos fios.

\subsection{Referencial teórico metodológico e procedimentos de pesquisa}

Basicamente, nossa metodologia esta orientada para o processo criativo. Desta forma todo o nosso referencial teórico esta fundamentado na reflexão acerca dos processos de produção e consumo de moda e da teoria e metodologia do design, bem como nos conceitos e elementos que serão apropriados para a concepção da coleção de fios.

Clark (2008), baseado no conceito advindo do movimento "slow food, ressalta em seu artigo intitulado "Slow + fashion - an oximoron - or a promise for the future...?" a relevância de se incorporar uma abordagem mais lenta aos processos de concepção e produção do vestuário, baseada principalmente na valorização dos recursos locais, em sistemas de produção mais transparentes e em produtos com maior valor agregado com maiores ciclos de vida útil, na perspectiva de minimizar alguns aspectos indesejáveis do atual sistema global, especialmente o desperdício extremo de recursos e falta de preocupação com questões ambientais (CLARK, 2008).

O Autor ao estabelecer valores para essa nova abordagem na dinâmica do sistema moda, denominado "slow fashion", nos introduz linhas de reflexão, em que há aspectos que consideramos importantes para o desenvolvimento de um produto têxtil e de moda, são: valorização dos recursos locais; sistemas de produção transparentes e com menor intermediação entre produtor e consumidor; produtos sustentáveis que tenham um maior ciclo de vida útil, que sejam mais valorizáveis e que difundam outros valores de consumo ${ }^{1}$.

\footnotetext{
1 É importante ressaltar, porém, que a presente pesquisa foca-se em uma fase de concepção, onde ainda, do ponto de vista técnico, será experimentada a viabilidade de uma produção efetiva dos fios das fibras de paina,
} 
Coincidentemente, essa abordagem proposta acima vai ao encontro das dinâmicas desenvolvidas nos processos artesanais, pois são dinâmicas mais lentas que possibilitam um conhecimento maior sobre a entrada e saída dos recursos. Além disso, esses processos, em muitos casos $^{2}$, estão ligados a um saber popular acerca das técnicas e sobre o uso de recursos naturais, importante para a valorização dos patrimônios natural e cultural do Brasil, associada ao desenvolvimento social.

Entretanto, a produção artesanal dentro do design, seja ele de moda ou referente a outros tipos de produtos, é uma questão que geralmente evoca muitas discussões, havendo na literatura inclusive uma clara dificuldade na definição do próprio conceito de design (BONSIEPE, 2011; BORGES, 2011; CALDAS, 2004 e CARDOSO, 2010).

Essa discussão conceitual, e, portanto de caráter teórico e metodológico é fruto de um processo histórico acerca da origem do design. Conta Cardoso (2010) que a noção de design surge juntamente com o processo de industrialização, quando novas estratégias de organização do trabalho e a aceleração no ritmo de inovação tecnológica implicaram numa gradativa substituição das pequenas oficinas pelas grandes fábricas. Esse processo alterou o modo de produção artesanal para uma produção em série o que exigiu uma divisão de tarefas para aceleração do processo, resultando na separação das etapas de concepção do artefato das etapas de produção propriamente dita. O designer surge então com o papel de desempenhar as etapas de concepção, criação do objeto.

A partir desse momento é que o design será reconhecido como uma faculdade própria da modernidade. Entretanto, nem por isso, significa que antes da Revolução Industrial não havia design enquanto atividade de projeção de um artefato (CARDOSO, 2010). Esse é um dos problemas encontrados nas atuais definições para design, pois

bem como o seu tingimento. Nesse sentido, embora a preocupação ambiental seja uma das principais motivações da proposta de coleção, não é objetivo desta pesquisa desenvolver a coleção sob uma estratégia de Life Cycle Design (LCD) ou realizar uma Avaliação do Ciclo de Vida (ACV) dos fios. Sendo, nossa atuação em relação à dimensão ambiental focada nas diretrizes internacionais para a conservação da natureza (UICN, 1984; UICN, PNUMA e WWF, 1992; WRI, UICN e PNUMA, 1992): como uso de matérias primas nativas, obtidas de recursos renováveis e biodegradáveis e uso do processo de produção artesanal, que implica num processo de produção mais transparente e podem favorecer a melhoria das condições de vida de populações rurais.

${ }^{2}$ No caso do design têxtil, podemos citar como exemplo os trabalhos conduzidos por Renato Imbroisi em parceria com artesãos de várias regiões do Brasil e apresentados no livro Desenho de fibra: Artesanato têxtil no Brasil (KUBRUSLY e IMBROISI, 2011). 
geralmente elas estão associadas à noção de padronização e produção em larga escala, rejeitando outras atividades projetuais que fogem à lógica de produção industrial (CALDAS, 2004 e CARDOSO, 2010).

Assim, sendo a faculdade do design geralmente reconhecida como própria da era moderna, e tendo, conforme afirma Bürdek (2006), o desenvolvimento da teoria e método do design enraizado nas condições histórico-culturais e sociais, podemos considerar que o design é muitas vezes reproduzido com base na estrutura de pensamento moderno.

A visão de mundo predominante na sociedade esteve sempre fundamentada na estrutura de pensamento linear, que é considerada a estrutura do pensamento moderno. 0 princípio desse tipo de pensamento é o de que todos os elementos são gerados a partir de uma sequência de causas e efeitos, sem interferência externa. Ele tem sua origem na filosofia grega, com Aristóteles, e mais tarde será difundido por Descartes, pai filosofia moderna (MORIN, 2005).

A deficiência desse tipo de pensamento, segundo Morin (2005) é a tendência ao reducionismo, pois dificulta a compreensão de fenômenos complexos, excluindo as influências externas. Isso significa que os fenômenos são encarados de forma fragmentada, sem compreendê-los de um ponto de vista mais amplo e transdisciplinar.

Morin (2005) em sua obra Introdução ao Pensamento Complexo convoca-nos para uma tomada de consciência sobre as limitações, insuficiências e carências dentro do pensamento que ele chama de simplificador, considerado um "modo mutilador de organização do conhecimento, incapaz de reconhecer e apreender a complexidade do real" (MORIN, 2005 p. 10). Conforme reflete o Autor, os problemas mais graves que hoje enfrenta a humanidade são fruto de um processo cego e incontrolado do conhecimento, que se fundamenta no paradigma simplificador. Já o paradigma complexo, elucidado por ele, dá forma a uma nova concepção de mundo e surge a partir do questionamento a cerca do sentido do conhecimento.

A importância da noção de complexidade pode ser evidenciada na citação abaixo:

[...]sendo todas as coisas ajudadas e ajudantes, causadas e causantes, estando tudo ligado por um laço natural e invisível, considero impossível conhecer as partes sem conhecer o todo, como também considero impossível conhecer o todo sem conhecer particularmente as partes" (MORIN, 2005 p.148). 
Embora esta pareça uma discussão recente, já na segunda metade do século XIX, há cerca de um século depois da revolução industrial, os problemas de uma produção massificada, que priorizasse a quantidade em função da qualidade, vinham sendo reconhecidos e refletidos por artistas e intelectuais da época. Isso deu origem a movimentos de vanguarda como o Arts and Crafts (Artes e Ofícios), na Inglaterra, liderado pelo designer têxtil e escritor William Morris, e a Escola de Bauhaus, na Alemanha, dirigida por Walter Gropius. O primeiro propunha a recuperação dos métodos semi-fabris e artesanais e buscando maior integração entre projeto e execução, visando condições de vida e trabalho mais humanas à população (CARDOSO, 2010 e BÜRDEK, 2006). Já a Bauhaus era menos radical do ponto de vista da produção em larga escala, mas propunha a aproximação entre a indústria, as artes e a manufatura artesanal, possibilitando a criação de objetos ao mesmo tempo artísticos e comerciais.

Segundo Bonsiepe (2011), o design se distanciou da ideia de "solução inteligente de problemas", vinculando-se mais à lógica do sistema moda, representada pela efemeridade e obsoletismo rápido, pelo jogo estético-formal e pela glamurização (BONSIEPE, 2011). Para Rybczynski (2005), crítico de arquitetura, citado por Bonsiepe (2011) “[...] 'design', na opinião pública, se identifica com envoltórios: a carcaça de um computador; o corpo de uma lapiseira; a armação de um par de óculos" (RYBCZYNSKI, 2005 apud BONSIEPE, 2011 p. 18).

Esse é um bom exemplo dos efeitos da visão fragmentada do conhecimento (MORIN, 2005) no campo do design, representada pela dificuldade de associação entre as disciplinas projetuais e o conhecimento científico (que possuem tradições e critérios de excelência distintos), discutida por Bonsiepe (2011). Ele defende a ideia de que "o design deve recorrer a conhecimentos científicos quando a temática o exige" (p. 18), reforçando o que propomos sobre a importância da integração entre a criação e a pesquisa científica.

No contemporâneo, podemos considerar a definição de design do International Council of Societies of Industrial Design - ICSID

[...] uma atividade criativa cujo objetivo é estabelecer as qualidades multifacetadas de objetos, processos, serviços e seus sistemas em ciclos completos de vida. [...] é o fator central do projeto de humanização de tecnologias inovadoras e o fator crucial de intercâmbio cultural e econômica (ICSID, 2013, tradução nossa). 
De acordo com o ICSID (2013) o design tem a missão de: melhorar a sustentabilidade global e a proteção ambiental (ética global); oferecer benefícios e liberdade para toda a comunidade humana, individual e coletiva; beneficiar e apoiar usuários finais, produtores e protagonistas de mercado (ética social); apoiar a diversidade cultural, apesar da globalização do mundo (ética cultural); oferecer produtos, serviços e sistemas, que sejam expressivos (semiologia) de e coerentes (estética) com sua própria complexidade, de forma que o conjunto dos vários ramos de atividade do design possam aumentar ainda mais - e de uma forma coral com outras profissões relacionadas - o valor da vida (ICSID, 2013).

Baseada então neste conceito e valores, a concepção da coleção de fios que apresentamos visa o desenvolvimento de um novo produto têxtil, aliando, dentro da atividade projetual, criação, associada principalmente aos aspectos estético-formais; pesquisa e inovação, dadas por meio das pesquisas teórica e experimental com as fibras de paina. Nessa mesma direção, buscamos contemplar na atividade projetual diferentes formas de saber-fazer e lógicas de produção, na perspectiva de sugerir um design têxtil e de moda mais consciente das limitações do paradigma simplificador, que consideramos o principal responsável pela difusão das lógicas de produção e consumo de moda criticadas por Clark (2008).

\subsubsection{Etnobotânica e etnodesing}

No contexto da presente pesquisa, onde destacamos a importância de valorizar técnicas artesanais e matérias primas presentes na cultura popular brasileira, a etnobotânica e o etnodesign são elementos primordiais dentro da nossa metodologia de criação. Não pretendemos fazer um estudo sobre estes conceitos, mas mostrar, inicialmente, que estas áreas podem contribuir para a criação e o desenvolvimento de uma coleção e que este caminho pode crescer com a aproximação da moda e de outros estudos como este.

Tanto a etnobotânica como o etnodesign são metodologias da pesquisa etnográfica. Porém, aqui não será realizada uma pesquisa etnográfica, mas sim o levantamento de dados secundários de algumas pesquisas de etnobotânica e etnodesign realizadas no Brasil no campo do artesanato têxtil. Esses dados etnográficos serão, na realidade, parte da pesquisa teórico-conceitual e um dos recursos da pesquisa técnico-experimental. Com esses dados pretendemos especialmente conhecer as técnicas manuais de fiação e tingimento e utilizálas nos processo de produção dos fios. 
Inicialmente, pretendíamos realizar a fase de levantamento dessas técnicas, bem como as demais atividades de desenvolvimento da coleção, junto a uma comunidade rural que tivesse domínio de técnicas têxteis. Entretanto encontramos limitações tanto no que se refere ao tempo para conclusão do Mestrado, quanto em termos metodológicos. Este último nos exigiria um amadurecimento muito profundo que requer mais tempo e mais conhecimentos sobre a pesquisa antropológica. Nesse sentido, a pesquisa assumiria também mais um caráter de estudo etnográfico do que um estudo sobre teoria e prática dos processos criativos do design têxtil, nos afastando do que propõe a linha de pesquisa adotada no programa: Projeto de Têxtil e Moda, que se dirige à teoria, método e prática do projeto no setor têxtil e da moda. Contudo, ainda assim, esta pesquisa se desenvolve vislumbrando a possibilidade de numa outra pesquisa a proposta de criação de fios de fibras de paina (e eventualmente outros tipos de fibras naturais vegetais) que apresentamos aqui ser colocada em prática em uma comunidade e atender seus interesses e necessidades.

O conceito de etnodesign consiste basicamente no estudo da cultura material de um dado grupo étnico. De acordo com (SARMENTO, 2006) o etnodesign surge "como proposta para resgatar processos e tecnologias próprias a grupos étnicos brasileiros", num contexto em que importantes conhecimentos sobre processos tecnológicos e o uso de matériasprimas tradicionais são negligenciados, em função de uma visão etnocêntrica. Cabe destacar, entretanto, que a nosso ver o etnodesign não se reduz simplesmente a resgatar conhecimentos próprios a esses grupos, mas da possibilidade de assimilar desses conhecimentos novas lógicas de criação e incorporar inovações que atendam as demandas das várias partes envolvidas no processo criativo, pois conforme propõe Mario Santiago, em seu Manifesto para um Etnodesign (2002), “O Etnodesign não deve ser entendido como uma atualização dos velhos modelos e propostas, ou a construção de um consenso", muito menos uma perspectiva de "enfoque estetizante", como sugeriu Bonsiepe (2011) ao relatar algumas iniciativas de aliança entre design e artesanato, em que elementos estético-formais da cultura popular são usados como mera inspiração para produção de objetos de design.

No que se refere à questão da valorização dos recursos locais, enquanto o etnodesign vem para contribuir com o conhecimento das técnicas e recursos tecnológicos próprios da cultura tradicional popular brasileira, nos apropriamos da etnobotânica com o intuito de explorar o conhecimento sobre o uso dos vegetais, mais especificamente as plantas têxteis e 
tintoriais, quanto às suas aplicações. Como é destacado pela União Internacional para Conservação Da Natureza - UICN (1984):

Frequentemente as comunidades rurais possuem um conhecimento profundo e detalhado dos ecossistemas e das espécies com as quais se encontram em íntimo contato, e sabem como aproveitá-los de maneira sustentável (UICN, 1984).

Assim, considerando que os valores da coleção estão associados a uma preocupação com aspectos socioambientais, temos os dados da etnobotânica no artesanato têxtil importantes elementos para a pesquisa sobre formas mais sustentáveis de uso dos recursos naturais (neste trabalho, mais especificamente, sobre o uso das fibras de paina e dos corantes naturais e a aplicação destes na produção têxtil).

Outro aspecto importante da pesquisa, associado aos recursos e características locais, é a expressão da identidade brasileira na criação. Considerando o histórico de formação do Brasil, na condição de colônia, com fortes relações de hierarquia (CHAUÍ, 2000), nossa sociedade carregou consigo a crença de que só é bom aquilo que está fora do pais, de forma que por muito tempo o processo de reconhecimento e expressão da identidade nacional no design foi limitado, motivo pelo qual o Brasil ganhou fama pela ausência de criações autênticas e pela cultura da cópia (CALDAS, 2004). Como descreve Avelar (2009), “[...] a sociedade colonial contentava-se com a extração predatória de matérias-primas e a produção agrícola para exportação, em nada contribuindo para a valorização da quaisquer características locais" (AVELAR, 2009 p. 103). A Autora descreve de forma detalhada a trajetória histórica dessa crença (de "o que é bom está lá fora") dentro do campo da criação de moda. De forma resumida, ela tem seu início marcado pela chegada da Família Real, quando os hábitos brasileiros adquirem características de gosto voltadas para a Europa, e passa a ser questionada mais expressivamente a partir da década de 1990, quando no governo Collor advém abertura de mercado, exigindo das empresas, que até então usualmente recorriam à prática da cópia para o "desenvolvimento" dos seus produtos, uma atualização das estratégias e abordagens de mercado para competir com o mercado mundial. Neste momento, o artesanato brasileiro passou a ser visto como uma alternativa para criações nacionais mais autênticas (AVELAR, 2009). Porém, Caldas (2004) debate que essa nova conjuntura de mercado, somada a necessidade de dar aos produtos nacionais uma identidade, levou a algumas movimentações no campo da moda, que embora bem 
intencionadas também se estabeleceram carregadas de equívocos. O Autor menciona alguns exemplos na citação abaixo:

Procurando responder à necessidade de criação de um estilo brasileiro, outras
marcas, cobertas de boas intenções, passaram a fazer um apelo direto à produção
cultural brasileira em outros campos, tentando utilizar elementos plásticos de
arquiteturas, festas populares ou mesmo literatura, no design de moda, numa
transposição de primeiro grau, literal, sem elaboração - por mais que os estilistas
se esmerem em discursos que tentam provar o contrário. A tênue linha que separa
e une criação referenciada e pastiche foi rompida com frequência, nesses
exercícios de estilo, de qualquer modo necessários como etapa a ser vencida. Há,
no entanto, uma espécie de incompreensão metodológica, tanto sobre o que
tomar como referência quanto sobre como fazê-lo, que resulta ora em opacidade
em relação à cultura, ora em nacionalismo anacrônico (CALDAS, 2004, p. 157).

Essa observação de Caldas (2004) reforça o conceito de que a originalidade na criação exige um elevado nível de pesquisa e investigação, que não se limita apenas em explorar recursos estéticos de maneira óbvia. A criação de moda deve ser acima de tudo uma criação engajada, balizada em fundamentos de uma profunda pesquisa teórico-conceitual e prática. Assim, neste trabalho, ao utilizamos como referência elementos do artesanato têxtil brasileiro, pretendemos dar originalidade e identidade ao processo criativo por meio da materialidade (ao explorar recursos e técnicas têxteis populares), da abordagem que se dá aos processos produtivos, sendo capaz de extrair do conhecimento popular não apenas os elementos materiais, mas também os valores que estão por detrás das dinâmicas de produção e relação com os recursos. Porém, compartilhando com o que defende Avelar (2009), a originalidade e identidade da moda brasileira não implicam na utilização apenas do artesanato, e que este é um de tantos caminhos para tornar uma criação original.

Para Bonsiepe (2011) a identidade do design pode se manifestar de várias maneiras que ele divide em cinco modos de materialização, são: 1. Em forma de um grupo de características formais ou cromáticas; 2 . Na estrutura da taxonomia dos produtos, como os tipos de artefatos característicos de uma cultura; 3 . No uso de materiais locais e métodos de fabricação correspondentes; 4. Na aplicação de um método projetual específico; 5 . $\mathrm{Na}$ temática (necessidade) específica do contexto.

Assim como as possibilidades para manifestação da identidade no design são diversas, as formas de intersecção entre o design e o artesanato também podem revelar-se sob diferentes abordagens. A jornalista Adélia Borges, que também discute a questão do design, artesanato e a construção da identidade brasileira no design, abordou no seu último 
livro "Design + Artesanato: O Caminho Brasileiro" (2011) sobre a importância de parcerias que vêm sendo feitas entre designers e artesãos como iniciativas de "revitalização do objeto artesanal", como diz a Autora. Essas ações que vêm acontecendo e se intensificando desde a década de 80, resultam em alguns caminhos importantes, que conforme Adélia Borges (2011), estão distribuídos em seis diferentes eixos como: 1. melhoria das condições técnicas, visando o aprimoramento das técnicas para a melhoria das condições de trabalho do artesão e uma produção de maior qualidade; 2 . potencialidade dos materiais locais, considerando o uso e aproveitamento dos recursos locais; 3. identidade e diversidade, na perspectiva da manutenção e consolidação de uma linguagem para objetos que são criados coerente com as referências culturais locais; 4. construção das marcas, que não só pode mudar a visão dos produtos de artesanato no mercado como também pode fortalecer a questão da identidade desses objetos; artesãos como fornecedores, dando a possibilidade de interlocução entre os próprios artesãos e o mercado a e finalmente ações combinadas que resultam de uma serie de opções de abordagens e iniciativas para a "revitalização do artesanato" (BORGES, 2011).

Deste modo, no que diz respeito à questão da identidade no processo de criação, dentre as diferentes abordagens apresentadas por Bonsiepe (2011) e Borges (2001), é possível situar o presente trabalho dentro das iniciativas relacionadas especialmente ao uso de matérias locais.

\subsubsection{Tendências de moda e design}

Além dos dados etnográficos, as tendências de moda também são outro importante recurso para a pesquisa teórico-conceitual. Isso porque este é o modo clássico e formal pelo qual se dá o desenvolvimento de um produto têxtil para a moda e, embora ele não seja o recurso mais coesivo à proposta do trabalho (já que tem um foco no consumo de massa), alterá-lo exigiria mais tempo e estudo. Por outro lado, utilizá-lo significa permear as estratégias do modus operandi da indústria da moda e facilitar a inclusão de produtos no mercado.

As tendências de moda são geralmente projetadas por escritórios que estudam pelo mundo tendências de comportamento e consumo da sociedade. Com base nas suas pesquisas, esses escritórios publicam cadernos de estilo, conhecidos como Bureaux de Style, onde apresentam as prospecções moda e sugerem temas, conceitos, cartelas de cor para a criação (FRINGS, 2005; LEÃO, 2002 e VICENT-RICARD, 1989). Assim, como esclarece Leão 
(2002): “A principal missão de um 'Bureaux de Style' é descobrir as tendências que afetarão o comportamento do consumidor e traduzi-las em guias para a criação" (p. 63-64).

Os Bureaux de estilo surgiram na década de 50, com a consolidação da moda pret-àporter, com o intuito de organizar e orientar a indústria têxtil por meio de sugestões de cores, materiais e formas.

Inicia-se a partir daí uma aliança entre criação de moda e a indústria. A necessidade da pesquisa de tendências surge num contexto em que a moda passa a ser produzida em escala industrial. O vestuário passa então a ser consumido na forma de produtos padronizados, prontos para o uso, ao contrário do que ocorria antes da moda pret-à-porter, segundo uma demanda especifica, em que se criava com exclusividade aos clientes. Assim, a pesquisa de tendência se tornou primordial para orientar a indústria têxtil e de confecção já que esta deverá propor o que será consumido nas próximas estações. Por outro lado, a moda também ganha um poder de persuasão, pois ao prever tendências também as determina, além de promover de certa forma uma estandardização estética (LEÃO, 2002).

Ainda que a nossa intensão para a coleção não seja uma produção em escala industrial e que esteja pautada em valores de produção e consumo de moda mais lentos (CLARK, 2008), é essencial conhecer essas tendências de caráter estético-formal e de comportamento, pois a proposta principal aqui, além de obter uma aceitação do mercado, é difundir outros valores de consumo dentro do próprio consumo.

\subsection{Procedimentos de pesquisa}

O desenvolvimento de uma coleção propriamente dita envolve tanto uma pesquisa teórica acerca do tema e conceitos que serão explorados, quanto uma pesquisa prática, em que a viabilidade da ideias e conceitos é testada mediante aos recursos técnicos disponíveis.

O presente trabalho apresenta-se dividido nas seguintes etapas:

\section{i. Pesquisa teórico-conceitual}

a. Pesquisa bibliográfica de estudos feitos na área da etnobotânica, sobre o uso popular das fibras de paina e corantes naturais, assim como suas propriedades na aplicação têxtil; 
b. Pesquisa bibliográfica de estudos etnográficos sobre as técnicas artesanais populares fiação e tingimento ${ }^{3}$;

c. Pesquisa das prospecções de moda e estilo sugeridas no bureaux de estilo Textile View Magazine.

\section{ii. Pesquisa técnico-experimental}

a. Estudo técnico experimental das técnicas para fiação: nesta etapa pretende-se testar, por meio das técnicas pesquisadas na etapa anterior, a possibilidade de transformar as fibras de paina e diferentes misturas desta com algodão e lã em um fio;

b. Estudo técnico experimental das técnicas de tingimento: nesta etapa pretende-se testar, utilizando as técnicas de tingimento pesquisadas na etapa anterior, a possibilidade de tingir os fios de paina. Os corantes serão num primeiro momento selecionados conforme a disponibilidade das matérias primas, e, posteriormente, segundo a cartela de cores escolhida para a coleção.

\section{iii. Desenvolvimento da coleção de fios:}

a. Desenvolvimento do tema e conceitos da coleção;

b. Criação da ambiência (painel semântico), baseada no tema e conceitos explorados;

c. Definição da cartela de cores;

d. Desenvolvimento dos fios.

\footnotetext{
${ }^{3}$ A proposta inicial da pesquisa visava à elaboração de uma coleção de protótipos (maquetes) de tecido, explorando todas as etapas da produção têxtil e empregando uma ampla gama de técnicas - desde a fiação e o tingimento até as várias técnicas de transformação dos fios em tecido. Porém, ao lidar com uma nova fibra, da qual ainda se desconhece de forma aprofundada as técnicas para seu manuseio e transformação, o desenvolvimento das maquetes de tecido com estas fibras se tornou uma etapa mais avançada, a ser realizada num segundo trabalho. Assim, por ora, neste trabalho decidimos limitarmo-nos à experimentação de criação de fios, que não deixam de ser protótipos têxteis, porém, não com tantos processos e técnicas agregados como nas maquetes de tecido.
} 


\section{Pesquisa teórico-conceitual}

Como mencionamos na Introdução, o método que delineamos para o desenvolvimento da coleção de fios abrange a pesquisa teórica, a pesquisa prática e a criação dos fios propriamente dita. Este capitulo diz respeito à primeira etapa do trabalho, a pesquisa teórico-conceitual, em que foram levantados os principais conhecimentos sobre as matérias primas e técnicas no âmbito da cultura têxtil popular brasileira (etnobotânica e etnodesign) e as principais tendências de moda e consumo no Brasil e no mundo.

A relevância dessa fase da pesquisa diz respeito não apenas à delimitação de aspectos técnicos para as fases experimentação e o desenvolvimento dos fios, mas também à fundamentação da importância do conhecimento popular ao sugerir um conceito de coleção alinhado à abordagem de uma moda mais lenta, como propõe Clark (2008) com "slow fashion". Além disso, buscamos também nesta fase da pesquisa demonstrar a importância de se estabelecer uma aliança entre esses conhecimentos, difundidos nos estudos na área da etnobotânica e etnodesign, e referencias mercadológicas da moda, explorando-as como um mecanismo para facilitar a inclusão de produtos no mercado.

O presente capitulo abordará então os seguintes assuntos: as matérias primas, breve discussão sobre o uso das fibras naturais na produção têxtil no Brasil e descrição das principais propriedades e dados sobre uso da paina; as técnicas, descrição sobre as técnicas artesanais de fiação e tingimento natural no Brasil; as tendências, breve descrição sobre tendências de moda e consumo pesquisadas no bureaux Textile View Magazine e blogs de design do Brasil e do mundo.

\subsection{As Fibras Naturais}

A maior virtude do reino humano é ser um eficiente organismo cósmico de criatividade. O maior vício é a pretensão de ser diferente de todo o resto e estar no domínio. Inventamos a realidade que agora nos açoita porque o artifício mágico nos distanciou da natureza e de tudo o mais, alimentada essa distância pela pretensão de domínio. Todos agora experimentamos dificuldade de identificar nossa natureza, uma afirmação que parece piada, pois como não seria natural sermos da natureza? Não somos! Assim de complicada é nossa situação, inventores de realidades. O que leva a outro assunto mais delicado ainda; sendo responsáveis por ter inventado a realidade que nos açoita somos responsáveis também por reinventá-la para criar outra melhor (Oscar Quiroga, Vícios e Virtudes, 28 julho 2011). 
As fibras têxteis apresentam diversas origens e podem ser classificadas em fibras naturais e fibras manufaturadas, sendo que as primeiras dividem-se em vegetais, animais e minerais e, as segundas dividem-se basicamente em artificiais e sintéticas. A principal matéria- prima no caso das fibras artificiais, como a viscose e o acetato, é a celulose vegetal e, no caso das fibras sintéticas, como a poliamida e o poliéster, o petróleo (OLIVEIRA, 1997).

Historicamente as fibras naturais são utilizadas pelo homem para a fabricação de tecidos e vestimentas desde culturas milenares, sendo que o linho e o algodão destacam-se como as principais fibras de origem vegetal utilizadas pelos povos antigos. De acordo com dados da Associção Brasileira da Indústria Têxtil e Confecções - ABIT (2013), ainda hoje o algodão é a fibra de maior importância econômica no Brasil, representando aproximadamente 55\% do consumo industrial de fibras e filamentos em 2012 (ABIT, 2013).

As fibras manufaturadas surgiram a partir da Revolução Industrial juntamente com o desenvolvimento científico-tecnológico, seguido do consumo evolutivo destas em relação às fibras naturais, especialmente a partir da década de 1970. As grandes vantagens das fibras químicas, especialmente as sintéticas, é que além de serem muito mais baratas (o gradativo avanço tecnológico cada vez mais possibilita a diminuição dos gastos dentro de seus processos produtivos), as peças confeccionadas a partir delas são de muito mais fácil manutenção, pois secam rapidamente e em geral não precisam ser passadas (RIBEIRO, 1984).

Embora ainda as fibras de algodão representem mais de $50 \%$ do consumo mundial de fibras, sendo produzidas em mais de cem países no mundo e utilizando cerca de $2,4 \%$ das áreas cultiváveis (31 milhões de hectares) (KOOISTRA, PYBURN e TERMORSHUIZEN, 2006), dados do consumo industrial de fibras têxteis fornecidos pela ABIT (2013) demonstram um crescente consumo de fibras manufaturadas, que vêm progressivamente deslocando o mercado das fibras naturais. O consumo das fibras manufaturadas (artificiais e sintéticas), que em 1970 era praticamente o mesmo das demais fibras naturais (lã, seda, linho/rami e juta), cerca de $22 \%$, rapidamente superou o consumo destas, e em 2012 , esse número foi representado por $45,6 \%$ do total de fibras, contra apenas $1,3 \%$ das demais fibras naturais, excetuando o algodão (ABIT, 2013). O histórico de consumo das fibras têxteis pode ser melhor visualizado no Gráfico 1 a seguir. 
Gráfico 1 - Consumo industrial de fibras e filamentos no Brasil

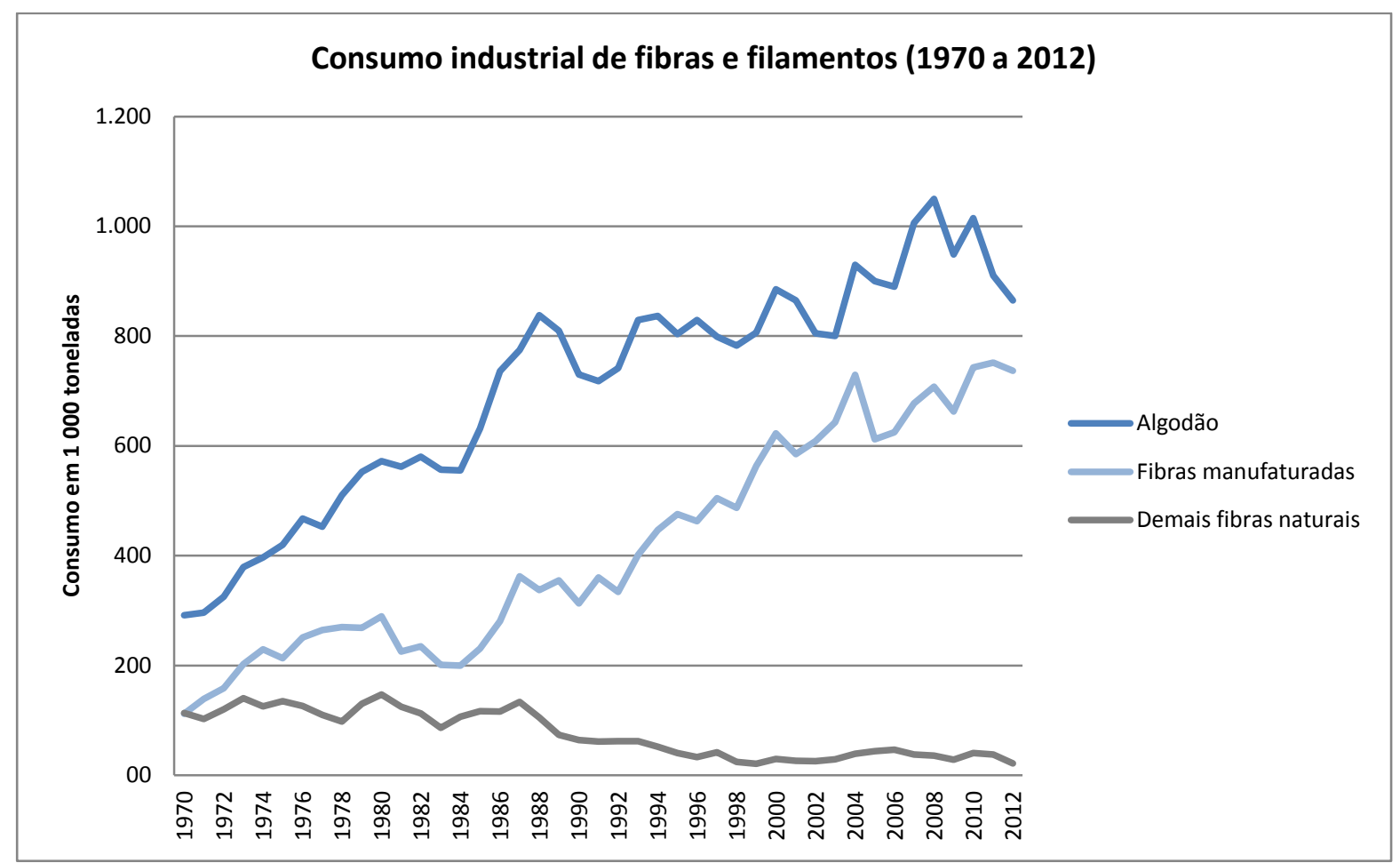

Fonte: gráfico gerado pelo autor a partir de dados fornecidos pela ABIT (2013)

Segundo Andrade et al (2001):

O segmento produtor de fibras sintéticas, que integra o chamado complexo petroquímico-têxtil, se caracteriza por ser intensivo na utilização de capital e matérias-primas, o que torna suas empresas altamente dependentes de freqüentes investimentos em pesquisa e modernização, como forma de aumentar a eficácia de suas operações industriais, reduzir seus custos e assegurar a sua competitividade internacional. Além desses aspectos, este segmento também se notabiliza por alta sofisticação tecnológica que exige a utilização, em larga escala, de microeletrônica e mecânica de precisão, além de velocidade rigidamente controlada e climatização adequada, dentre os diversos fatores que contribuem para sua complexidade tecnológica (ANDRADE, CORREA e SILVA, 2001, p. 3).

Além do alto investimento econômico e tecnológico, expressado acima, existem outras desvantagens das fibras manufaturadas em relação às naturais. As fibras naturais também possuem grande importância ecológica uma vez que são biodegradáveis (FINKLER, SCAPINI, et al., 2005) (FINKLER, SCAPINI, et al., 2005); e ao contrário das fibras manufaturadas, sua obtenção e produção não demandam processos químicos de alto custo ambiental (FINKLER, SCAPINI, et al., 2005). Fibras vegetais também apresentam vantagens como: baixa densidade, baixo consumo de energia, baixo custo, baixa abrasividade, atoxicidade, reciclabilidade, boas propriedades mecânicas, geração de empregos rurais, utilização como reforço para vários tipos de plásticos e excelentes propriedades termoacústicas (SALAZAR, CARASCHILL e LEÃO, 2005). 
Segundo (PEREIRA, RODRIGUES, et al., 2003) a introdução de fibras vegetais alternativas que sejam de origem nativa brasileira é uma forma de valorização do produto nacional, bem como uma forma de preservar a matéria prima nativa. Além da sua contribuição social como uma atividade alternativa de geração de renda para comunidades locais e tradicionais.

O ano de 2009 foi eleito o Ano Internacional das Fibras Naturais pela Organização das Nações Unidas para Agricultura e Alimentação - FAO, dada a importância dessas fibras referente ao aspecto social, gerando emprego na agricultura, evitando o êxodo rural e como fonte de renda em áreas carentes em todo o mundo (FAO, 2009).

Mesmo assim, pode-se ainda levantar dúvidas com relação aos benefícios no que se refere aos aspectos socioambientais das fibras naturais. A agricultura hoje é uma das atividades que consome água em abundancia, e já tendo em vista o esgotamento progressivo deste recurso, tornar-se-ia o cultivo de fibras vegetais inviável no futuro? E com a tão temida fome mundial, não precisaríamos transformar nossos solos exclusivamente em produtores de alimentos? Esses questionamentos nos parecem relevantes, porém relativos, já que água e solo são recursos renováveis e existem formas alternativas de produção à monocultura de grande extensão, de reduzido impacto ambiental, como o cultivo orgânico (KOOISTRA, PYBURN e TERMORSHUIZEN, 2006). O que há hoje, e que acaba por reproduzir esse medo generalizado com relação ao esgotamento dos recursos naturais, são práticas de consumo insustentáveis que extrapolam a capacidade limite dos ecossistemas se autorregularem (DUARTE e QUEIROZ, 2009).

A prática da monocultura de larga extensão do algodão é um exemplo entre as práticas de produção e cultivo não sustentável. Segundo Lima (apud FINKIELSZTEJN, 2005) e Kooistra et al (2006) cotonicultura está entre as atividades mais depredadoras. Finkielsztejn (2005) também relata problemas associados à monocultura do sisal, que também não é considerada sustentável, além das péssimas condições de trabalho para quem lida com sua cultura. Sabe-se de longa data que a monocultura de grande escala é altamente problemática para os ecossistemas naturais, uma vez que exige o desmatamento de extensas áreas de mata virgem, causando problemas de erosão, salinização, acidificação, desertificação, entre outros impactos consequentes do uso indevido do solo (KOOISTRA, PYBURN e TERMORSHUIZEN, 2006). Essas práticas agrícolas exigem o uso cada vez mais 
intenso de produtos químicos para o controle de pragas e adubo, provocando contaminação do solo e lençóis freáticos e afetando a biodiversidade da fauna e flora (POSEY, 1987). Conforme debate Posey (1987) sobre a realidade da agricultura na região da Amazônia no final da década de 80:

As tendências atuais visando a atingir o desenvolvimento parecem inspirar-se em fontes antigas: tecnologias impostas de fora e variedades de cultivares "aperfeiçoados" selecionados ao acaso. Dessas práticas resulta a proliferação de grandes plantas monocultoras, mediante a introdução de máquinas modernas de fábricas distantes, que se mantêm a custa de sistemas de sustentação fundamentados em fertilizantes e pesticidas. Em publicações respeitáveis, alguns cientistas chegam a afirmar que os solos amazônicos podem ser cultivados sem descanso [...] bastando para isso a ajuda de certos "estimulantes" químicos. Omitem, porém, qualquer consideração, análise ou prova quanto aos efeitos ecológicos e sociais de tais produtos químicos sobre essa região tão vasta como a Amazônia. Esse raciocínio esdrúxulo conduziu a alterações perturbadoras na ocupação da terra (Marbira-Scazzochio 1980:iii-xiv; Hecht 1983:177). Esse é o grande dilema do desenvolvimento: os camponeses, pequenos agricultores e índios não têm condições de arcar com os custos das máquinas e produtos químicos agrícolas; e o sistema ecológico tem menos condições ainda para amoldar-se ao desmatamento em grande escala e à monocultura. A persistir esta situação, o mundo está fadado a uma série de "revoluções verdes" enegrecidas pelo transplante de tecnologias por atacado, sem que se levem em conta as conseqüências sociais (POSEY, 1987, p. 173).

Embora passados mais de 25 anos, essa é uma realidade que ainda persiste no modelo agropecuário brasileiro e as suas amplas decorrências de caráter social e ambiental foram claramente elucidadas num documentário em 2008 intitulado "O veneno está na mesa", recentemente divulgado na internet.

Assim, quando falamos que fibras naturais oferecem vantagens no que se refere aos aspectos socioambientais frente às fibras manufaturadas, não significa que podemos afirmar que hoje as práticas de produção, cultivo, beneficiamento, entre outras etapas, das fibras naturais na indústria têxtil sejam mais sustentáveis, ou menos danosas ao meio ambiente, que a produção das fibras manufaturadas (DUARTE e QUEIROZ, 2009), como foi ponderado por Finkielsztejn (2005), a utilização de fibras naturais como matéria-prima não tem uma relação direta com sustentabilidade e sua aplicação deve ser investigada verificando-se sua adequação. Entretanto o que se leva em conta aqui é, sobretudo, o potencial que o uso das fibras naturais apresentam, considerando critérios ambientalmente e socialmente éticos para seu cultivo e produção, a partir de uma analogia das práticas de produção têxtil realizadas por populações tradicionais do Brasil e da América Latina (EXPÓSITO, 2010; 
DUARTE, 2009; TARANTO e MARI, 2003; MOREAL, FONSECA e ALTAFIN, 1984; GEISEL e LODY, 1983; GARCIA, 1981; PALEVECINO, 1981;).

Nessa perspectiva, segundo Finkielsztejn (2005):

Deve-se conceber a substituição da matéria-prima por renováveis inserida no ciclo de vida do sistema-produto, e não isoladamente. Além disso, sua disponibilidade e integração das tecnologias envolvidas com o meio ambiente, considerando-se as particularidades geográficas e culturais de cada região, são questões fundamentais na elaboração de produtos sustentáveis que utilizam essas fibras. Este conjunto de aspectos permite considerarmos as ações relevantes para a efetiva redução de impactos ambientais e sociais (FINKIELSZTEJN, 2006, p. 69).

Portanto, ao determinar critérios para redução de impactos ambientais e sociais nos processos de cultivo e produção das fibras devem ser observadas todas as etapas do ciclo de vida do sistema-produto.

O número de plantas que podem fornecer fibras utilizáveis em nossa flora mundial é extraordinariamente elevado. Em 1924 Schiling chegou a estimar cerca de 2.300 espécies fibrosas em todo o planeta e, nesse particular, a flora tropical encerra recursos inesgotáveis em potencial (MEDINA, 1959). Porém esses recursos, até o momento, foram muito pouco explorados, que de acordo com Medina (1959) se deve aos seguintes fatos:

- falta de conhecimento sobre as exigências e o comportamento das plantas quando

- introduzidas em cultura;

- insuficiência de preparo das fibras;

- similaridade de comportamento industrial e usos com as fibras tradicionais, o que, como sucedâneas, não comportam competição econômica;

- descontinuidade de oferta comercial do produto e, consequentemente, incapacidade de estabelecer uma tradição no mercado.

Enfim, o que vemos, conforme evidenciado no estudo de Medina (1959), é que embora muitas fibras apresentem propriedades têxteis excelentes para diversas aplicações, poucas se justificam, em termos de "viabilidade econômica", para seu cultivo e produção.

A respeito da questão da viabilidade econômica comenta Schumacher (1985) que,

No vocabulário corrente de termos condenatórios existem poucas palavras tão decisivas e concludentes como 'não-económico'. Se uma actividade é taxada de não-ecónomica, o seu direito a existência não é simplesmente posto em causa: é negado com energia (SCHUMACHER, 1972, p. 40). 
Entendemos assim que a questão da viabilidade econômica das fibras naturais está intimamente ligada à estrutura agropecuária dominante no Brasil e a dinâmica de produção recorrente na indústria têxtil e de vestuário, e fundamentam-se de uma "lei" a ser repensada: produzir mais no menor tempo possível. Como o próprio Schumacher (1972) o faz, é preciso questionar o "[...]que significa dizer que uma coisa é não-económica?", esclarecendo que de acordo com os critérios da ciência econômica moderna, atribuir uma atividade como economicamente inviável significa dizer que esta não oferece "um lucro razoável em termos de dinheiro" (SCHUMACHER, 1972, p. 40 e 41). Entretanto este é um valor apenas compatível e válido para a parcela da população de vive segundo os padrões urbano-industriais, e é ainda assim muito questionável, visto que essa sociedade dominante vive na atualidade uma intensa e acelerada redefinição de conceitos e valores que se projetam gradativamente nos comportamentos de consumo e consequentemente no mercado e economia.

Nesse contexto é que recorremos a etnobotânica no presente trabalho. Conforme define Camargo (2003), a etnobotânica consiste no estudo do conhecimento sobre os vegetais em diferentes contextos sócio-culturais, estuda a relação homem/planta e se ocupa, como descreve a autora, em “(...) resgatar dos grupos humanos o saber quanto aos papéis que as plantas desempenham nos diversos ambientes culturais e os significados que os grupos sociais Ihes atribuem" (CAMARGO, 2003, p. 30).

A etnobotânica foi considerada disciplina de caráter não científico, por tratar de questões puramente subjetivas, porém, aliada a novas técnicas de pesquisa e no interesse em conhecer as raízes culturais dos costumes, hábitos e tradições da sociedade contemporânea, passou a ter importância e aplicabilidade em diferentes disciplinas e áreas do conhecimento humano (CAMARGO, 2003). É um conceito da antropologia inserido dentro de um conceito mais amplo, o de etnobiologia. A etnobiologia, conforme explica Posey (1987),

[...] é essencialmente o estudo do conhecimento e das conceituações desenvolvidas por qualquer sociedade a respeito da biologia. [...] É o estudo do papel da natureza no sistema de crenças e de adaptação do homem a determinados ambientes (POSEY, 1987, p. 15).

Deste modo, o uso do conceito de etnobotânica no contexto específico do presente trabalho ascende no propósito de explorar o conhecimento tradicional popular e as formas 
de uso da paina para aplicação têxtil, indo muito além da pura e simples descoberta (ou "redescoberta") do potencial têxtil dessa fibra, mas buscando uma alternativa aos modos convencionais de produção e o uso dos recursos naturais, que leva em conta a conservação e valorização dos patrimônios natural e cultural brasileiro. O uso dos corantes naturais também estão contemplados na etnobotânica, e também será descrito neste capítulo.

\subsubsection{A paina}

Paina ou kapok (como é conhecida mundialmente) é o nome dado aos pelos de frutos de várias espécies vegetais da família Bombacaceae. Trata-se de filamentos sedosos unicelulares que crescem na região interna da parede dos frutos, são chamados de borras vegetais ou lã de fruto. Na aparência, a paina assemelha-se à pluma de algodão, porém é mais fina e mais sedosa ao tato e também mais elástica (PIO CORRÊA, 1984; ERHARDT, BLÜMCKE, et al., 1976 e MEDINA, 1959).

Além das espécies da família Bombacaceae, como Ceiba pentandra, Ceiba sumaúma e Chorisia speciosa, há também uma gama imensa de espécies vegetais de famílias diversas que produzem material semelhante também conhecido popularmente como paina. Mas de acordo com Medina (1959) e Erhardt et al (1976) a espécie Ceiba pentandra é quem oferece a legítima paina. Conhecida vulgarmente como sumaumeira, ou simplesmente sumaúma, a Ceiba pentandra é uma espécie arbórea de grande porte, variando entre 30 a 40 metros de altura e 50 metros de diâmetro, sendo uma das maiores árvores da flora mundial e a maior da América do Sul (PIO CORRÊA, 1984 e LORENZI, 1998). A variedade caribaea é típica do Brasil equatorial, e das Guianas (PIO CORRÊA, 1984). Além da sua imponência devido ao porte é uma bela árvore, pelo seu aspecto geral e também pelas suas raízes tubulares, que sobressaem da terra e formam verdadeiras "cabines", servindo como habitação para os índios e sertanejos (PIO CORRÊA, 1984). As árvores dessa espécie também têm grande importância cultural para os povos da mata e fazem parte de lindas histórias e lendas criadas pelas civilizações da América Pré-Colombiana. 
Figura 1 - Prancha da espécie Ceiba pentandra

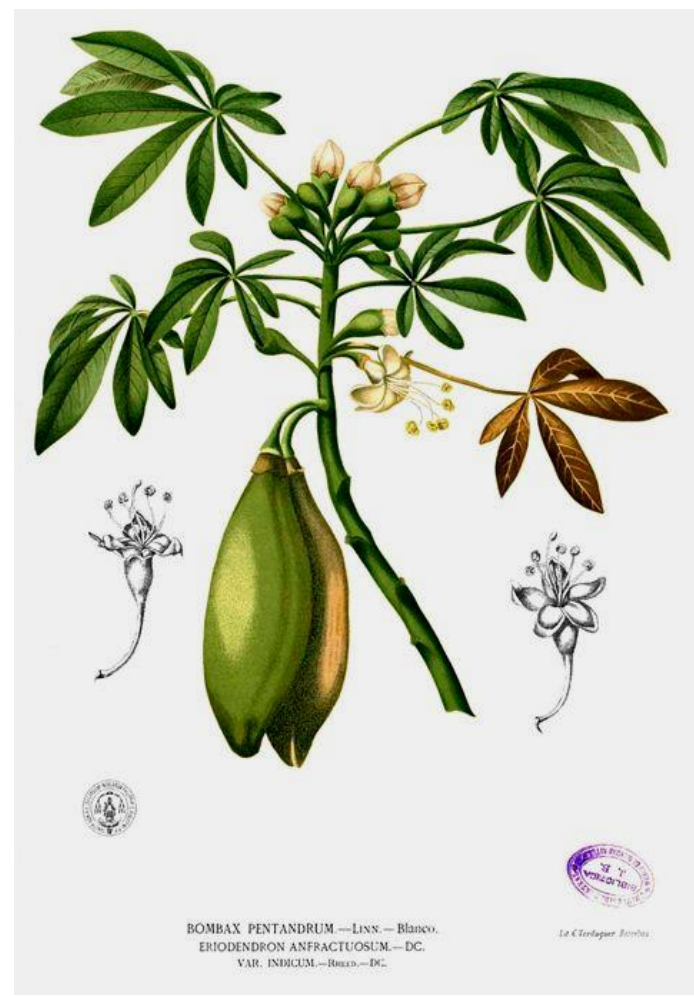

Fonte: Flora Filipinas

Figura 2 - Árvore da espécie Ceiba pentandra

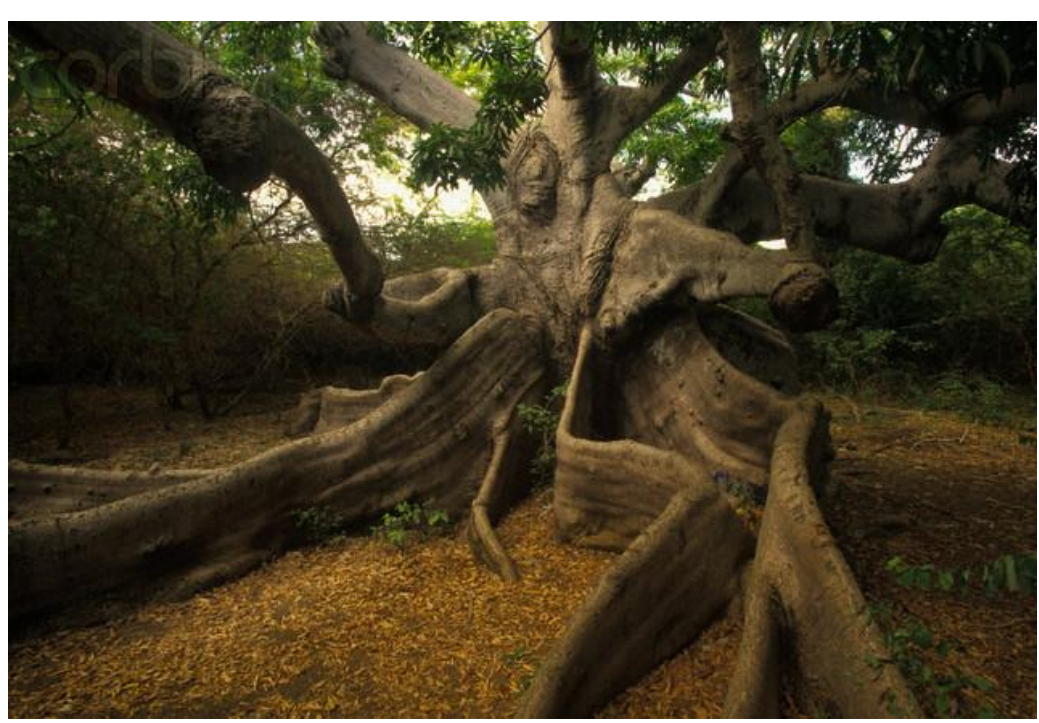

Fonte: Corbis imagens 
Figura 3 - Prancha da espécie Chorisia speciosa

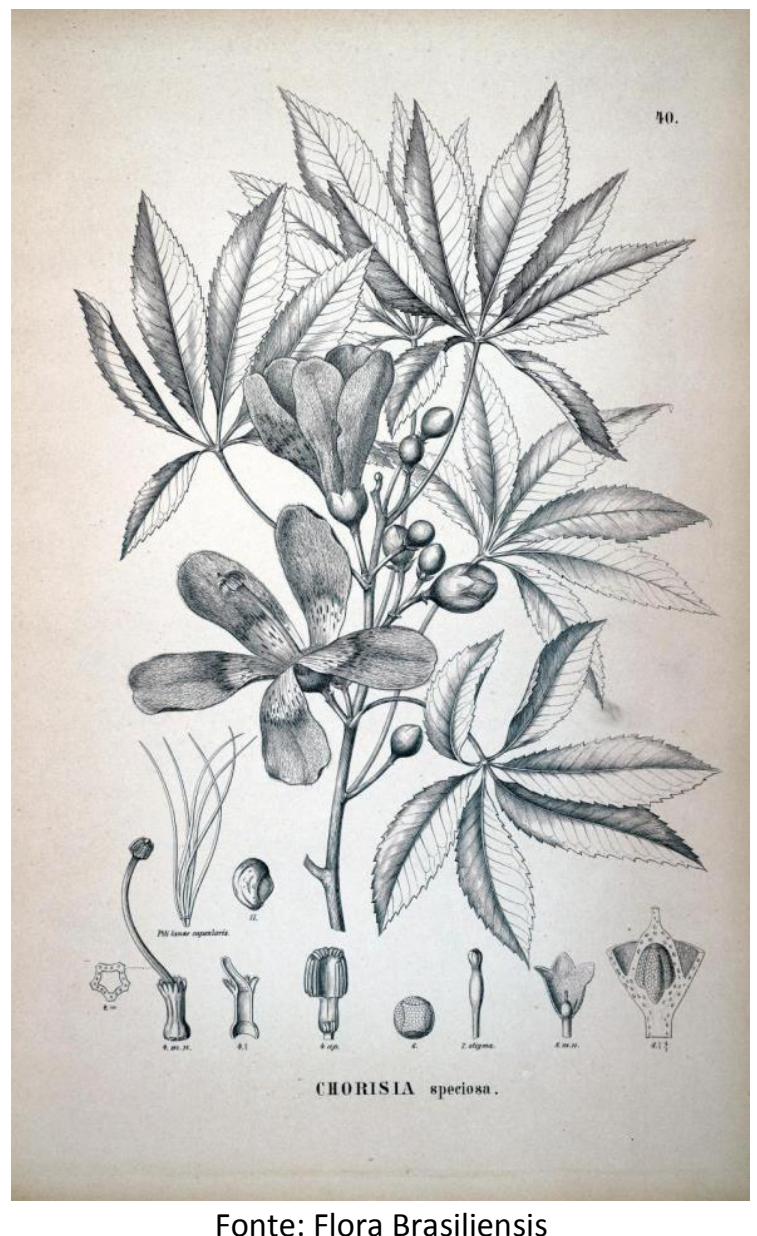

A espécie Chorisia speciosa, da qual foi extraída a paina utilizada no desenvolvimento dos fios, é nativa do sul do Brasil, Paraguai e Argentina. A planta se adapta bem em solos pouco férteis, secos e arenosos, e sob condições climáticas bastante variáveis. A planta em geral floresce entre dezembro e janeiro e seus frutos, de onde é extraída a paina, atingem a maturidade entre junho e outubro. A árvore começa dar frutos a partir do quinto ano. De acordo com Medina o plantio da espécie pode ser dar com distâncias entre 8 e 10 metros.

A planta adulta, sob condições favoráveis de crescimento, chega a produzir de 300 a 600 frutos, e a massa das fibras obtidas por fruto variam entre 10 a $20 \mathrm{~g}$. De acordo com Medina (1959), Os frutos devem ser colhidos antes de se abrirem, evitando que a paina se desprenda e seja levada pelo vento. Os frutos colhidos são dispostos em local limpo e abrigado de sol, chuva e vento até que abram espontaneamente e em seguida são separadas das cascas e as sementes.

A fibra de paina foi escolhida como matéria-prima para o desenvolvimento do projeto de coleção porque além de apresentar propriedades físicas, químicas diferenciadas 
com relação às demais fibras vegetais, tais como: notável elasticidade e leveza, imputrecibilidade e resistência a insetos e microrganismos, flutuabilidade e boa capacidade de isolamento térmico e acústico, é uma fibra fina e lisa (MEDINA, 1959), que confere um toque macio ao material, semelhante à seda.

Embora a paina apresente essas excelentes qualidades no que se refere aos quesitos conforto táctil e aspecto visual, comercialmente, sua aplicação mais convencional se dá em enchimentos de colchões, travesseiros, coletes salva-vidas, devido a sua leveza. Tendo esta fibra sido pouco explorada para aplicação têxtil propriamente dita, pois sua lisura tornou-se uma limitação no processo de fiação (ERHARDT, BLÜMCKE, et al., 1976). Como descreve Medina (1959), seus pelos são retos e lisos, faltando-lhes a torção do algodão ou as garras da lã, o que torna a fiação uma operação difícil. Contudo, isso não representa a impossibilidade de fiá-la.

Mesmo diante dessa limitação apontada por Erhardt et al (1976) e Medina (1959), encontramos registros de que outrora a paina da espécie Chorisia speciosa era utilizada para produção de fios e tecidos por populações rurais instaladas no Triângulo Mineiro - MG (MOREAL, FONSECA e ALTAFIN, 1984) e em Hidrolândia - GO (GARCIA, 1981). E mais recentemente, encontramos no mercado um produto confeccionado com essa fibra em mistura com o algodão. É o caso da linha de fios para malharia e tricô Baby Cotton Kapok produzida pela marca inglesa Sublime Yarns.

Figura 4 - Fios compostos de uma mistura 85\% algodão e 15\% paina da marca Sublime Yarns
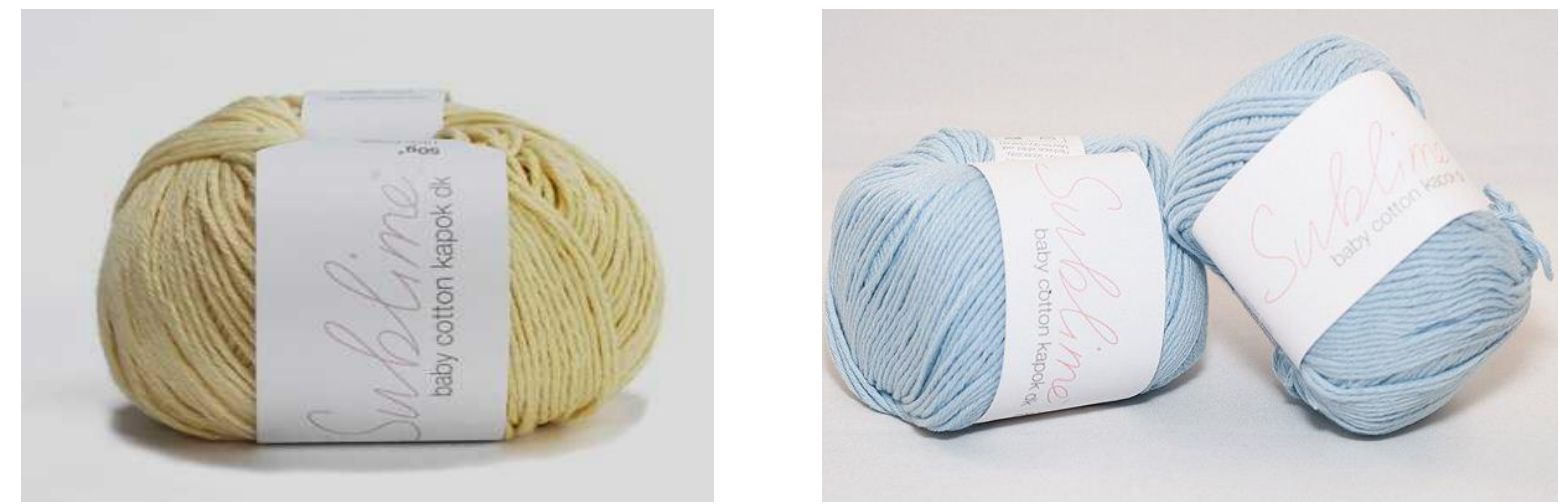

Fonte: Dillinger Fabrics

A possibilidade de utilização das fibras de paina na produção fios é constatada nos exemplos acima, estabelecendo como desafio técnico para a fase experimental da pesquisa a produção de um fio $100 \%$ paina, bem como experimentação de distintas misturas com 
fibras de algodão e lã (que até o momento se desconhece o uso com a paina), utilizando os processos artesanais de fiação que seguem descritos a seguir.

\subsection{As técnicas têxteis no Brasil}

Há importantes trabalhos, realizados especialmente na década de 80 , a respeito do artesanato têxtil brasileiro que registraram técnicas tradicionais populares como fiação, tecelagem, feitio de rendas, cestaria, tingimento, entre outras, praticadas na esfera doméstica e/ou rural em várias regiões do Brasil. No que se refere à fiação, tecelagem e tingimento na região do Triângulo Mineiro - MG e adjacências de Goiânia - GO podemos citar Moreal et al (1984) e Garcia (1981). De uma maneira mais abrangente, também na década de 80, O Projeto Artesanato Brasileiro, organizado pelo Instituto Nacional do Folclore junto a Fundação Nacional de Artes - FUNARTE, concebeu uma série de publicações sobre o artesanato no Brasil que registaram técnicas populares de tecelagem e fiação, rendas, carpintaria, entre outras em várias regiões do país. Ainda hoje, o estado de Minas Gerais, em especial a região do Triângulo Mineiro, é bastante reconhecido pela atividade têxtil artesanal e algumas comunidades estão inseridas em projetos ligados a políticas públicas de conservação do patrimônio cultural, é o caso do Centro de Fiação e Tecelagem Dona Belmira, em Urberlândia, objeto de um estudo mais recente realizado por Duarte (2009). Nesta linha também podemos citar trabalhos encabeçados por ONGs como o ArteSol, idealizado pela antropóloga Ruth Cardoso, que atua em comunidades nas Minas Gerais e demais comunidades espalhadas por vários estados do Brasil e a Mundaréu, que desenvolve projetos com comunidades especialmente no estado de São Paulo. Essas, entre outras iniciativas de Organizações não governamentais são importantes referências de trabalhos que buscam a preservação do saber-fazer artesanal e a inserção de comunidades que o detêm na sociedade.

Este conhecimento popular a respeito do saber-fazer artesanal é o que entendemos aqui por etnodesign, e é o foco deste item, onde descrevemos brevemente algumas técnicas artesanais utilizadas no Brasil nos processos de criação têxtil. As descrições estão baseadas, na sua maioria, nesses trabalhos de caráter etnográfico realizados sobre as várias categorias do artesanato têxtil no Brasil. 
Antes de prosseguirmos com a descrição das técnicas que levantamos, há, porém, importantes considerações éticas a respeito do saber popular tradicional que precisam ser pontuadas, considerando a possibilidade de futuramente desenvolvermos este trabalho junto a uma comunidade.

Nos últimos anos parcerias vêm sendo feitas entre designers e artesãos como iniciativas de "revitalização do objeto artesanal", como diz Borges (2011). Essas ações que vêm acontecendo e se intensificando desde a década de 80 , têm resultado em alguns caminhos importantes. Um dos profissionais reconhecido no Brasil por essas iniciativas é o tecelão e designer Renato Imbroisi, que tem ganhado grande visibilidade no ramo do design têxtil. No final da década de 80 começou um trabalho com as artesãs de uma comunidade rural, localizada no município de Muquém - Minas Gerais. Imbroisi atuou e tem atuado em oficinas de criação em conjunto com artesãos de várias regiões do país e juntos (designer mais artesão) estão criando, produzindo e disponibilizando no mercado produtos artesanais de qualidade, com forte referência cultural.

O exemplo de Renato Imbroisi entre outros importantes designers brasileiros que têm trilhado nesta mesma perspectiva evidencia como as técnicas artesanais de produção têxtil e matérias primas nativas do Brasil, podem ser incorporadas no processo criativo do design têxtil. Entretanto há ressalvas importantes de serem registradas no que se refere a essas parcerias entre designers e artesãos. Hoje há várias instituições governamentais e não governamentais desenvolvendo projetos nessa área com visões, em alguns casos, divergentes segundo a abordagem apropriada a ser dada, conforme a realidade de cada comunidade (BORGES, 2011). Essa é uma questão bastante delicada, pois há casos em que uma abordagem equivocada nos coloca novamente numa postura etnocêntrica de superioridade, recriminada por Sarmento (2006), conforme citamos anteriormente. Borges (2011) faz considerações importantes a respeito disso, que valem a pena ser aqui transcritas apesar da sua extensão:

\footnotetext{
A aproximação entre designer e artesão é, sem dúvida, um fenômeno de extrema importância pelo impacto social e econômico que gera e por seu significado cultural. Ela está mudando a feição do objeto artesanal brasileiro e ampliando em muito o seu alcance. Nessa troca, ambos os lados têm a ganhar. O designer passa, no mínimo, a ter acesso a uma sabedoria empírica, popular, á qual não teria entrada por outras vias, além de obter um mercado de trabalho considerável. $\mathrm{O}$ artesão, por sua vez, tem ao menos a possibilidade de interlocução sobre a sua prática e de intervalo no tempo para refletir sobre ela.
} 
No entanto, é preciso pôr o dedo na ferida: nessa onda, têm ocorrido também muitas experiências ruins, muitos equívocos. Eles decorrem, via de regra, de uma postura que vê designers ou estudantes de design - ou seja, pessoas com instrução formal - como superiores aos artesãos. O poder, a clarividência, o domínio estão com os instruídos. Os "outros" entram com sua habilidade, seu jeito com as mãos e, no máximo, com a familiaridade com as matérias primas. É muito fácil passar uma semana num lugarejo, com acesso a matérias-primas e tecnologias locais, e sair com uma coleção de objetos lindos. Também é relativamente fácil publicar belas fotos com esses objetos e com os rostos das pessoas que participaram das oficinas nas revistas especializadas ou mostrá-las em palestras nos congressos internacionais, sob o rótulo de "responsabilidade social" ou "ajuda humanitária". 0 difícil é fazer com que esse trabalho tenha significado e relevância para a comunidade local e, assim, possa ser continuado (BORGES, 2011, p. 137-138).

Embora a presente pesquisa, segundo o procedimento metodológico adotado, não exigiu contato direto com nenhum tipo de comunidade, queremos deixar claro aqui qual é a nossa visão a respeito dessa aproximação e sobretudo nossa postura em relação ao conhecimento popular tradicional, na perspectiva de que o conhecimento gerado e resgatado nesta pesquisa possa ser, num segundo momento, posto em pratica em uma comunidade, como já mencionamos.

Conforme consta no Convênio sobre a Biodiversidade Biológica do Programa das Nações Unidas para o Meio Ambiente o conhecimento tradicional é:

[...] un cuerpo de conocimientos fundado por un grupo de pueblos de una a otra generación que viven en contacto cercano a la naturaleza. Incluye un sistema de clasificación, un conjunto de observaciones empíricas acerca del medio ambiente local y un sistema de autogestión que rige el uso de los recursos (PNUMA, 2001, p. 5).

No Brasil, o acesso ao conhecimento tradicional é controlado no território nacional e regulamentado pelo Decreto $n^{\circ} 4.946 / 03$, com o objetivo de impedir usos indevidos em pesquisa e desenvolvimento de novos produtos ou bioprospeç̧ão visando à aplicação industrial e aproveitamento comercial. Isso quer dizer que lidar com o conhecimento tradicional exige uma postura ética, sobretudo porque ele é essencial dentro das comunidades que o detêm para a manutenção dos seus modos de vida, da cultura e do manejo dos recursos naturais. No tocante ao modo de vida tradicional e ao conhecimento que por meio dele se reproduz, ao contrário do que se costuma pensar, cabe destacar que compartilhamos da mesma visão posta pelo Centro Nacional de Desenvolvimento Sustentado das Populações Tradicionais - CNPT do Instituto Brasileiro do Meio Ambiente e dos Recursos Naturais Renováveis - IBAMA (2011).

As populações tradicionais não são sinônimo de populações atrasadas, populações refratárias ao progresso ou à modernização, pois uma população tradicional tem 
como característica principal sua relação de proteção ao meio ambiente, mesmo que para tal tenha que utilizar meios modernos [...] são uma antecipação das sociedades do século XXI pois se o homem no próximo século não se tornar um conservacionista, colocará em risco a sua própria sobrevivência (CNPT/IBAMA, 2011, p.2).

Isso corrobora com a nossa visão de que não só é possível incorporar inovações que possibilitem a melhoria da qualidade de vida das comunidades tradicionais e manutenção da sua cultura, como também é possível nós - sociedade "dominante" - assimilarmos, no mínimo, diferentes lógicas de vida, trabalho e relação com a natureza, também visando a melhoria da qualidade de vida. É, portanto, finalidade deste trabalho reapresentar e empregar esse tipo de conhecimento, obtido a partir de fontes secundárias, para demonstrar como é possível inovar e inserir distintas lógicas de concepção, produção e consumo na moda e design brasileiro que proporcionem benefícios sociais e ambientais.

\subsubsection{Fiação}

O processo de fiação é o conjunto de operações pelo qual se transforma fibras brutas em fios. Grosso modo, o preparo dos fios pode ser dividido nas seguintes etapas: 1. remoção das impurezas das fibras, 2. a cardação e 3. a fiação propriamente dita. Porém, cada tipo de fibra exige um tipo de preparação e as operações podem variar conforme as características de cada uma delas, dentre as fibras que relataremos aqui - algodão, lã e paina - as etapas de cardação e fiação propriamente dita são comuns entre às três fibras.

O algodão é a fibra que envolve maior número de etapas e instrumentos para o preparo do fiado, após colher as fibras de algodão e realizar uma limpeza prévia manual, o processo segue as seguintes etapas: o descaroçar, utilizando o descaroçador que separa as fibras das sementes do algodão; o bater ${ }^{4}$, feito utilizando o arco ou bodoque que é deslizado pelo fardo de algodão, trata-se de uma limpeza mais fina que remove impurezas mais difíceis e também serve para misturar melhor as fibras quando não há homogeneidade; a cardação, que se dá por meio das cardas, tem a função de dar maior orientação às fibras, dispondo-as de maneira uniforme e removendo demais impurezas e nós que restaram das etapas anteriores, resultando nas pastas; a fiação é a última fase, quando as pastas são

\footnotetext{
4 No estudo feito em Hidrolândia (GARCIA, 1981) algumas tecelãs consideram uma etapa quase que dispensável, dependendo das condições em que é realizada a colheita do algodão, ou quando o algodão é velho (quando foi armazenado por algum tempo). Além disso, consideram que o processo provoca muito desperdício do algodão, pois muitas fibras se soltam no processo.
} 
transformadas em fio estirando-se as fibras e dando-as torção, podem ser utilizados a roda ou o fuso (GARCIA, 1981 e MOREAL, FONSECA e ALTAFIN, 1984). A Figura 5 a seguir apresenta a sequência de etapas e seus respectivos equipamentos.

Figura 5 - Etapas da fiação do algodão

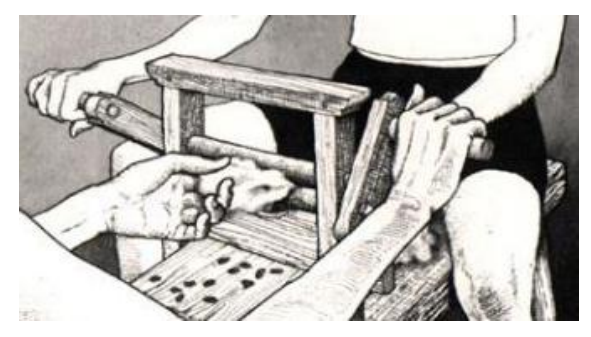

a. Descaroçar

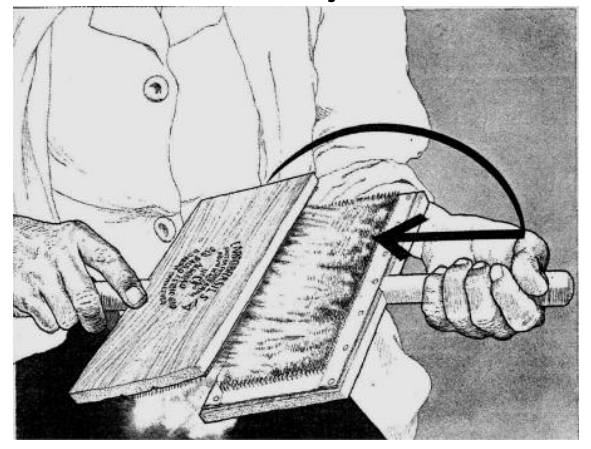

c. Cardação

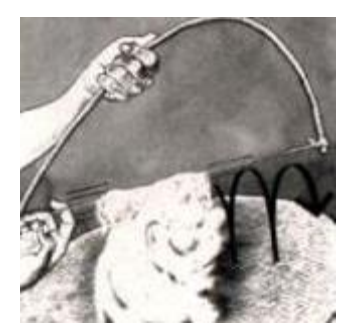

b. Bater

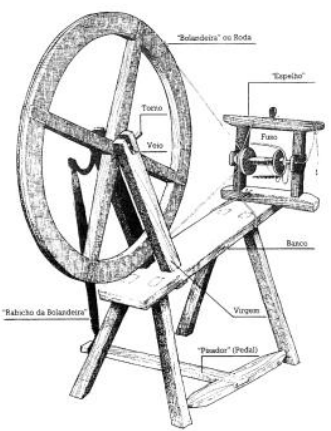

d. Fiação em roda

Fonte: Moreal, Fonseca e Altafin, 1984

Figura 6 - Fiação em fuso

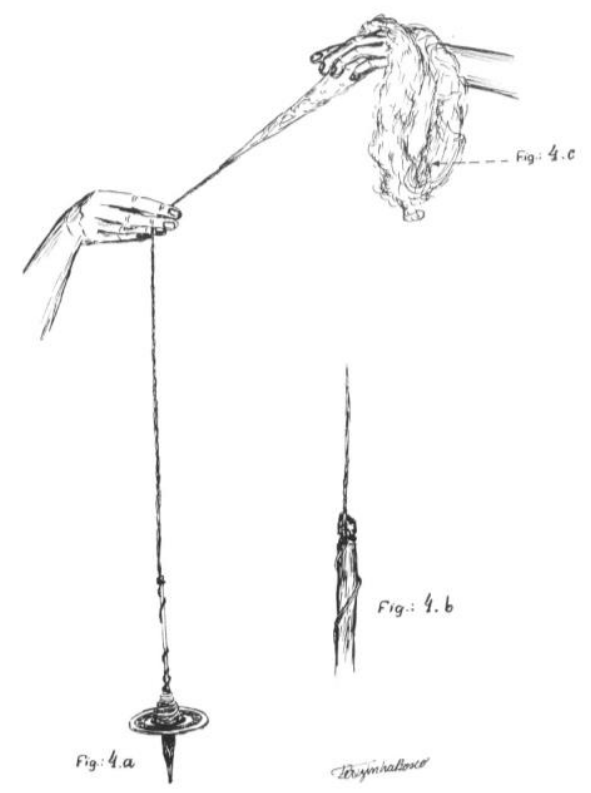

Fonte: Garcia, $19 \varepsilon$ 
No caso da lã, as etapas são similares, porém a limpeza começa antes mesmo da tosquia, conforme detalhado por algumas tecedeiras de Hidrolândia - Goiás (GARCIA, 1981):

[...] lava-se o carneiro com água e sabão, até que a lã fique livre de toda a sujeira, até mesmo de terra e ciscos; amarra-se o animal ao sol com corda bem curta, para ele que ele não se deite no chão e suje novamente a lã. Quando a água escorrer, penteia-se a lã e catam-se os carrapichos (GARCIA, 1981, p. 39 e 40).

Depois desse processo é que se faz a tosquia e em seguida é necessário triá-la.

Chegando em forma de um tosão inteiro, ou como punhados de vários carneiros, amontoados juntos, a lã precisa, primeiro, ser triada.

[...] A melhor vem dos flancos do animal. A lã das espáduas, do pescoço e do dorso já é inferior, enquanto a dos quadris, das pernas e da barriga vem geralmente muito embaraçada e suja (MOREAL, FONSECA e ALTAFIN, 1984, p. 17).

A triagem costuma ser feita não apenas para separação de diferentes qualidades de lã, mas também para separação dos tons de lã que podem variar do marrom ao bege ou do branco ao preto. No caso do processo relatado por Moreal et al (1984) em Minas Gerais a lã é também lavada depois da tosquia e triagem, para remoção da suarda e demais impurezas. A limpeza também é feita com água e sabão, podendo utilizar água morna para facilitar a remoção do excesso de gordura, evitando ferver a lã para não correr o risco de "feltrar" (MOREAL, FONSECA e ALTAFIN, 1984). Quando seca a lã, sobre um pano, é feita sua abertura, que não só ajuda a desembaraçar os pelos como a eliminar algumas impurezas restantes (GARCIA, 1981 e MOREAL, FONSECA e ALTAFIN, 1984). Depois desse preparo e limpeza preliminar das fibras o processo segue como o do algodão: cardação, transformando as fibras em pastas (Figura 7) e fiação, transformando as pastas em fios.

Figura 7 - Pastas de lã ou algodão produzidas após processo de cardação

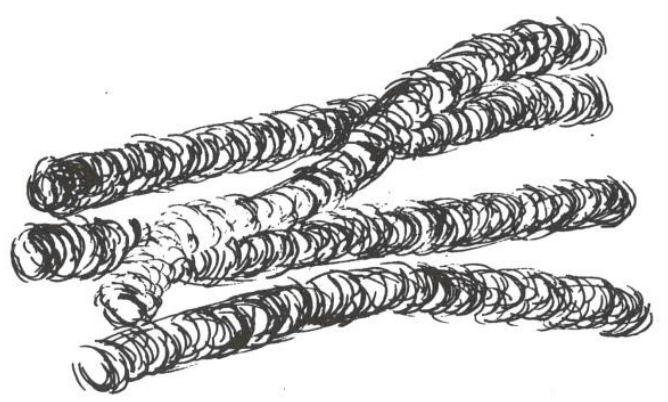

Fonte: Garcia, 1981

Os processos de fiação artesanal tanto do algodão, quanto da lã são largamente conhecidos e ainda bastante praticados no Brasil e não é muito difícil localizar, seja na literatura, seja em material audiovisual na internet, o saber popular sobre suas técnicas. 
Entretanto, no que diz respeito ao processo de fiação das fibras de paina, apenas duas literaturas nos forneceram indícios e dados, ainda que sem muitos detalhes, sobre o uso das fibras de paina para produção de fios. Garcia (1981), na tecelagem artesanal em Hidrolândia - Goiás, comenta sobre o uso dessa fibra, retirada dos frutos de plantas como a paineira e a barriguda (Chorisia speciosa), utilizada em mistura ao algodão para produção de fios. Moreal et al (1984), para nossa sorte, entra em mais detalhes, descrevendo como é feita a cardação da paina.

Algodão, lã e paina são cardados através da mesma técnica, sendo que, para que se possa cardar a paina, cujas fibras são brandas e têm pouca resistência, é preciso, antes de iniciar o processo, cobrir as cardas com uma pequena quantidade de algodão (MOREAL, FONSECA e ALTAFIN, 1984, p. 20).

Já as demais etapas são muito obscuras, embora se suponha que a limpeza possa ser feita como a do algodão, no descaroçador, ou mesmo manual e a técnica de fiação, conforme afirma Moreal et al (1984), é a mesma para qualquer tipo de fibra, alterando apenas a velocidade com que a fiandeira executa o trabalho.

Os fios podem ser torcidos de várias maneiras, resultando numa infinidade de tipos de fios com diferentes aspectos. O fio mais comum é o simples, que é aquele que é torcido em S ou Z, dependendo do sentido da torção que se dá (horário ou anti-horário). Além deste, Moreal et al (1984) faz menção a mais três tipos de fios comumente produzidos no

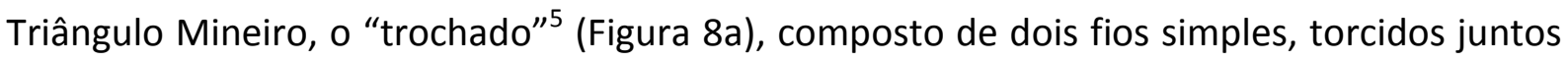
no sentido oposto ao de sua fiação original; o "fantasiado" (Figura 8c), que é fiado misturando-se duas pastas de cores diferentes ao mesmo tempo; e o "papo e finirisco" (Figura 8b), que apresentam intervalos de irregularidade, resultantes da variação de tensão que as mãos da fiandeira dá ás fibras no momento da fiação.

\footnotetext{
${ }^{5}$ Também citado por Garcia (1981), podendo ser também chamado de "misquiado".
} 
Figura 8 - Tipos de fios - a: "trochado" b: "papo e finirisco" c: "fantasiado"

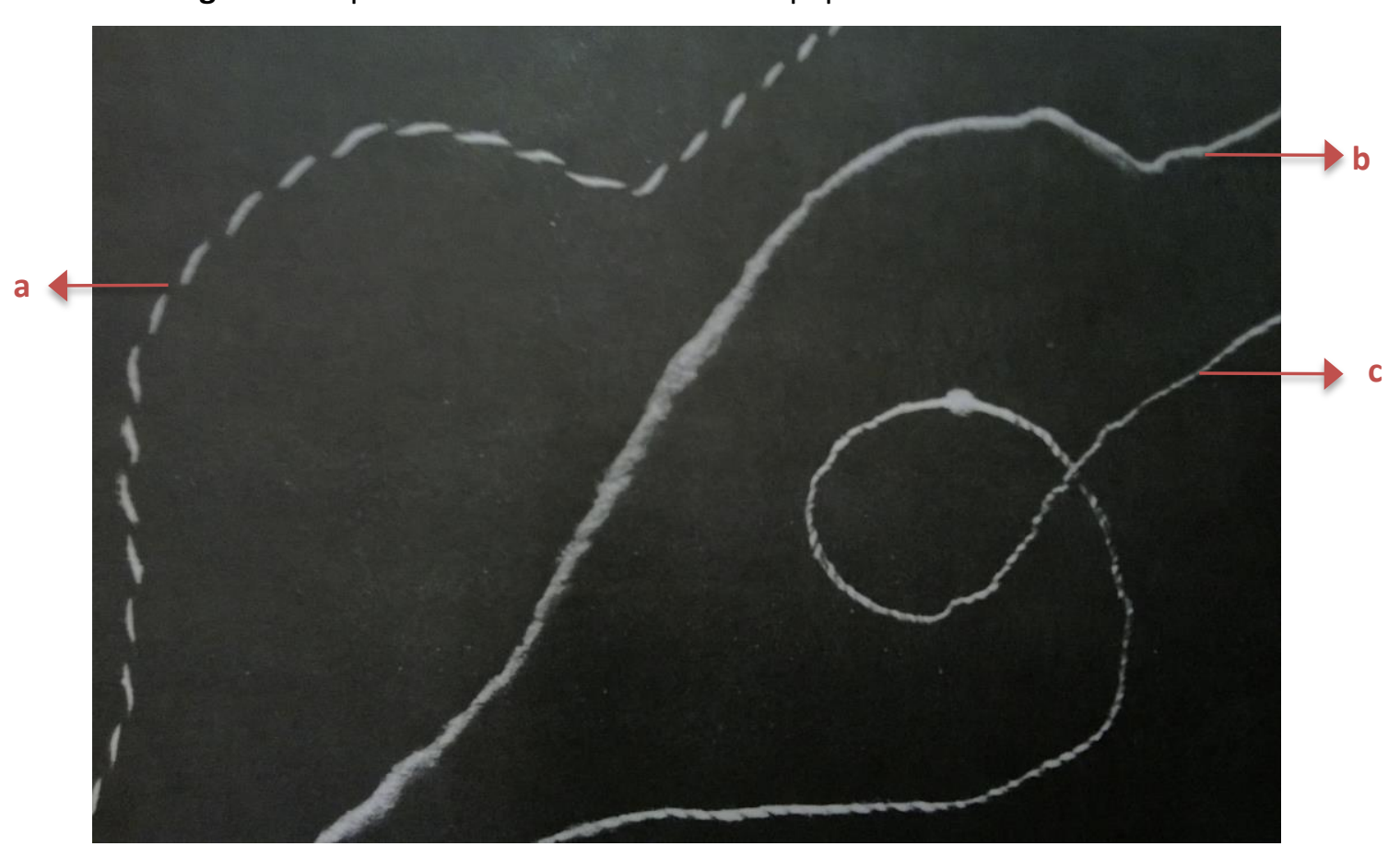

Fonte: Moreal, 1984

Quando preparado o fiado, estes podem ser tintos e finalmente trabalhados utilizando inúmeras técnicas de transformação de fios em tecido.

\subsubsection{Tingimento vegetal}

O tingimento é a fase da produção têxtil pela qual se dá cor aos fios ou tecidos já confeccionados. O tingimento vegetal para aplicação têxtil tem um histórico de esquecimento e substituição por produtos químicos sintéticos muito parecido com o das fibras naturais, em alguns casos, como é relatado por Garcia (1981) em Hidrolândia - Goiás, até mesmo na produção artesanal. Porém, no que diz respeito aos corantes naturais, há trabalhos de excelente qualidade, densos de informações sobre plantas e processos, tanto no diz respeito à descrição etnográfica dos processos de tingimento vegetal e conhecimento popular sobre as plantas tintoriais, como é o caso de Marcolina Martins Garcia no seu estudo etnográfico sobre a tecelagem artesanal em Hidrolândia - Goiás (1981), quanto trabalhos que tratam do tingimento artesanal de forma prática e didática incluindo informações mais técnicas do processo de tingimento vegetal e receitas bem definidas, caso de Eber Ferreira no livro Corantes naturais da flora brasileira: guia prático de tingimento com plantas (1998). Ambos os trabalhos serão referências importantes para fase prática da pesquisa, quando pretendemos experimentar alguns processos de tingimento da paina. 
Os corantes vegetais são pigmentações extraídas das várias partes das plantas como cascas, raízes, folhas, frutos e líquens (FERREIRA, 1998). De maneira geral o tingimento vegetal tem três fases importantes para que se garanta cor e durabilidade da cor no material têxtil: a limpeza das fibras; a fixação, que está relacionada ao preparo do mordente e o tingimento propriamente dito, que está relacionado ao preparo da tinta. Essas etapas de acordo com os trabalhos consultados (GARCIA, 1981 e FERREIRA, 1998), não necessariamente ocorrem nessa sequência e podem se dar, alternadamente, mais de uma vez no processo, entretanto, a limpeza adequada das fibras é obrigatoriamente a primeira etapa do processo de tingimento.

Ferreira (1998) descreve detalhadamente as diferentes formas de limpeza das fibras têxteis, de acordo com a sua natureza, antes do tingimento propriamente dito. Para as fibras de origem vegetal é aconselhável a limpeza em água junto a um detergente neutro e água oxigenada, que ajuda a clarear as fibras, o banho inicialmente é à frio e vai até $90^{\circ} \mathrm{C}$ de temperatura. Outra possibilidade de limpeza, ainda para fibras de origem vegetal, é utilizando o sabão de cinzas em um banho de água quente $\left(90^{\circ} \mathrm{C}\right)$. No caso das fibras de lã, usa-se também um detergente neutro, porém a temperatura da água do banho deve ser morna $\left(40\right.$ a $\left.50^{\circ} \mathrm{C}\right)$ para a lã não feltrar (FERREIRA, 1998).

A fixação dos corantes se dá pelo uso de mordentes ou produtos auxiliares, que facilitam a migração do corante para o interior da fibra a aplicação do fixador no processo de tingimento pode ocorrer tanto antes, quanto durante ou depois do tingimento propriamente dito, ou até mesmo ocorrer em mais de uma fase, porém, não são todos os tipos de tingimento que exigem a aplicação do mordente, já que muitas das plantas tintoriais já apresentam substâncias de fixação dentre as quais citaremos mais abaixo. Na comunidade tecelã estudada por Garcia (1981), as informantes geralmente relatam o uso da decoada (preparada à base de cinza vegetal) como fixador, que é usada no mesmo banho que se faz o preparo da tinta e o tingimento propriamente dito. Algumas também, depois das meadas já tingidas, levam-nas a um banho quente usando casca de goiabeira, umbigo de bananeira, casca de cajueiro ou no mentrasto, etapa que elas davam o nome de "apertá a tinta". A Autora também faz menção ao uso de produtos adquiridos no comércio como sal de cozinha (cloreto de sódio) ou pedra hume (alúmen de potássio) para a mesma finalidade. Ferreira (1998) divide os tipos de mordentes em três grandes grupos segundo a sua natureza, são 
eles: mordentes de origem vegetal, mordentes de sais orgânicos e mordentes de origem mineral. Dentre os mordentes de origem vegetal Ferreira (1998) faz menção do uso de espécie Rumex obtusifolius (lígua-de-vaca) e demais vegetais ricos em tanino, como as folhas de goiabeira, o umbigo de bananeira, cascas do barbatimão, entre outros, que podem ser aplicados durante ou após o banho de tintura. Todos os mordentes de origem vegetal influenciam no resultado final da cor, por isso cada vegetal deve ser utilizado adequadamente de acordo com a cor que irá se trabalhar. Já os mordentes de sais orgânicos são de difícil obtenção, porém, segundo Ferreira (1998), são os mais recomendados por não serem tóxicos são citados o acetato de cobre e o acetato de ferro, que podem ser obtidos por meio de receita caseira usando sucatas desses metais. Outro mordente de sais orgânicos é a decoada, solução obtida a partir de cinzas vegetais (FERREIRA, 1998). Garcia (1981) cita algumas plantas empregadas pelas tecelãs de Hidrolândia - Goiás no preparo da decoada ou "diquada", como costumam dizer no local. Segue na Tabela 1 abaixo:

Tabela 1 - Plantas para preparo da cinza para decoada

\begin{tabular}{c|c|c}
\hline Nome vulgar & Nome científico & Parte usada \\
\hline Aroeirinha & Não identificada & Madeira \\
\hline Arroz & Oryza sativa L. & Palha \\
\hline Barrigura & Chorisia crispiflora H.B.K. & Palha \\
\hline Feijão & Phaseo vulgaris L. & Talo \\
\hline Fumo & Nicotiana tabacum L. & Madeira \\
\hline Maria pobre ou mulher pobre & Não identificada & Grãos (caldo) \\
\hline Milho & Zeas mays L. & Madeira \\
\hline Pororoca & Não identificada &
\end{tabular}

Fonte: Garcia, 1981 (modificada)

Os mordentes de origem mineral são sais metálicos provenientes de algumas rochas, que proporcionam uma ligação estável entre o corante e as fibras, entre os mais utilizados, Ferreira (1998) cita o alúmen (pedra-ume), o sulfato de cobre, o sulfato de ferro e o bicromato de potássio.

No que se refere ao tingimento propriamente dito, Ferreira (1998) cita três tipos de tingimento, que a aplicação varia de acordo com cada tipo de planta da qual se extrai a tinta e o resultado final que se pretende dar às fibras. São eles: tingimento a frio (a tina), onde o 
banho é preparado em temperatura ambiente; tingimento a quente e o tingimento a quente com mordente. A flora nativa e cultivada brasileira dispõe de uma infinidade de espécies vegetais que oferecem matéria-prima para tingimento e uma imensa variedade de cores. Além da cor que o próprio corante oferece, vários fatores podem contribuir para a composição de diferentes matizes, como o recipiente utilizado para o tingimento, o tipo de mordente utilizado e mesmo a quantidade de vezes que se aplica às fibras o banho, que quanto maior o número de aplicações, mais intensa será a tonalidade da cor. Tanto Garcia (1981), num âmbito mais local, quanto Ferreira (1998), de forma mais abrangente no Brasil, apresentam uma relação de plantas tintoriais utilizadas popularmente para o tingimento têxtil. Nas tabelas abaixo segue uma relação dessas plantas dentro das suas respectivas famílias de cor. 
Tabela 2 - Plantas utilizadas para tingimento

\begin{tabular}{|c|c|c|}
\hline Planta & Nome científico & Parte da extração do corante \\
\hline \multicolumn{3}{|c|}{ Vermelho e rosa } \\
\hline Azedinha da horta & Rumex acetosa & Raiz \\
\hline Cedro rosa & Cedrela fissilis & Serragem do cerne \\
\hline Cipó de Imbé & Philodendron $s p$ & Caule \\
\hline Côco & Cocos nucifera & Mesocarpo \\
\hline Gardênia & Gardenia grandiflora & Fruto \\
\hline Ipê & Tabebuia sp & Serragem do cerne \\
\hline Nogueira & Juglans regia & Casca \\
\hline Peroba-rosa & Aspidosperma polyneuron & Serragem do cerne \\
\hline Pau-brasil & Caesalpinia echinata & Serragem do cerne \\
\hline Ruivinha & Relbunium hypocarpium & Raiz \\
\hline Sangra d'água & Cróton urucurana & Seiva da casca de árvores adultas \\
\hline \multicolumn{3}{|c|}{ Laranja } \\
\hline Côco & Cocos nucifera & Mesocarpo \\
\hline Girassol & Helianthus annuus & Flor \\
\hline Resedá (hena) & Lawsonia inermis & Folhas \\
\hline Urucum & Bixa orellana & Sementes \\
\hline \multicolumn{3}{|c|}{ Castanho } \\
\hline Acácia negra & Acácia mearnsii & Casca \\
\hline Avelãzeira & Corylus avellana & Folhas \\
\hline Barba-de-candéia & Usnea sp & Todo o líquen \\
\hline Castanheiro & Castanea sativa & Folhas \\
\hline Cerejeira & Prunus sp & Casca \\
\hline Cebola & Allium cepa & Casca \\
\hline Cipestre & Cupressus pyramidalis & Casca e fruto \\
\hline Goiabeira & Psidium guajava & Casca e raiz \\
\hline Macieira & Pyrus malus & Casca \\
\hline Nogueira & Juglans regia & Casca \\
\hline Pinus & Punus elliotti & Madeira / fruto \\
\hline Pereira & Pyrus cummunis & Casca \\
\hline \multicolumn{3}{|c|}{ Marrom } \\
\hline Castanheiro & Castanea sativa & Folhas \\
\hline Cafeeiro & Caffea arabia & Pó de semente seca \\
\hline Cerejeira & Prunus avium & Casca \\
\hline Castanheiro-da-índia & Aesculus hippocastaneum & Folhas \\
\hline Imbuia & Ocotea porosa & Serragem do cerne \\
\hline
\end{tabular}


Tabela 2 - Plantas utilizadas para tingimento (continuação)

\begin{tabular}{|c|c|c|}
\hline Planta & Nome científico & Parte da extração do corante \\
\hline \multicolumn{3}{|c|}{ Marrom avermelhado } \\
\hline Acácia negra & Acacia mearnsii & Casca \\
\hline Angico & Anadenanthera $s p$ & Casca \\
\hline Barbatimão & Stryphnodendron barbatiman & Casca \\
\hline Cajueiro & Anacardium occidentale & Casca e folhas \\
\hline Castanheiro-da-Índia & Aesculus & Casca \\
\hline Cerejeira & Prunus avium & Casca \\
\hline Resedá (henna) & Lawsonia inermis & Folha \\
\hline Nogueira & Juglans regia & Casca \\
\hline \multicolumn{3}{|c|}{ Amarelo ou dourado } \\
\hline Abacateiro & Persea americana & Folhas \\
\hline Açafrão-da-terra & Curcuma longa & Rizoma \\
\hline Arnica & Arnica montana & Raiz, folhas e flores \\
\hline Amoreira & Morus sp & Folhas \\
\hline Calêndula & Calendula oficinalis & Flores \\
\hline Camomila & Anthemis catula & Folhas \\
\hline Carqueja & Baccharis $s p$ & Folhas \\
\hline Castanheiro-daíndia & Aesculus hippocastaneum & Casca \\
\hline Cebola & Allium cepa & Casca \\
\hline Chá da índia & Camélia thea & Folhas \\
\hline Eucalipto & Eucalyptus spp & Serragem do cerne \\
\hline Figueira & Fícus carica & Folhas \\
\hline Jaqueira & Artocarpus heterophylla & Serragem do cerne \\
\hline Barba-de-candeia & Usnea sp & Todo o líquen \\
\hline Nogueira & Juglans regia & Folhas \\
\hline Macieira & Pyrus malus & Casca \\
\hline Pessegueiro & Prunus sp & Casca \\
\hline Pereira & Pyrus communis & Casca \\
\hline Quaresminha-do-campo & Trembleya phlogiformis & Galhos e folhas \\
\hline Taiúva & Maclura tinctoria & Serragem do cerne \\
\hline \multicolumn{3}{|c|}{ Verde } \\
\hline Castanheiro & Castanea sativa & Folhas \\
\hline Castanheiro-da-Índia & Aesculus hippocastaneumaes & Folhas \\
\hline Espinafre & Spinacea oleracea & Folhas \\
\hline Malva & Malva silvestres & Toda a planta \\
\hline Sabugueiro & Sambucus nigra & Fruto e folhas \\
\hline \multicolumn{3}{|c|}{ Verde oliva } \\
\hline Loureiro & Laurus nobilis & Folhas \\
\hline Castanheiro & Castanea sativa & Folhas \\
\hline Nogueira & Juglans regia & Folhas \\
\hline Língua-de-vaca & Rumex obtusifolius & Folhas \\
\hline
\end{tabular}


Tabela 2 - Plantas utilizadas para tingimento (continuação)

\begin{tabular}{|c|c|c|}
\hline Planta & Nome científico & Parte da extração do corante \\
\hline \multicolumn{3}{|c|}{ Verde oliva } \\
\hline Erva-mate & Ilex & Folhas \\
\hline Eucalipto & Eucalyptus spp & Folhas \\
\hline \multicolumn{3}{|c|}{ Caqui } \\
\hline Caquizeiro & Diospyros kaki & Fruto \\
\hline Romãzeira & Punica granatum & Casca do fruto \\
\hline Picão & Bidens pilosa & Planta e semente \\
\hline Jabuticabeira & Plinia trunciflora & Casca e fruto \\
\hline Cafeeiro & Coffea arábica & Semente moída \\
\hline Mangueira & Magifera indica & Casca do fruto \\
\hline \multicolumn{3}{|c|}{ Azul } \\
\hline Anileira & Indigofera tinctoria & Pó e folhas \\
\hline Arruda brava & Eupatorium laevis & Folhas \\
\hline Timbó mirim & Indigofera lespedezioides & Folhas \\
\hline \multicolumn{3}{|c|}{ Violeta } \\
\hline Jenipapeiro & Genipa americana & Fruto \\
\hline Mancha-vermelha & Herpothalon sp & Todo o líquen \\
\hline Pau-campeche & Haematoxylon campechianum & Serragem do cerne \\
\hline Pinheiro-do-Paraná & Araucária angustifolia & Casca e fruto \\
\hline \multicolumn{3}{|c|}{ Cinza } \\
\hline Palmeira de jardim & Areca catechu & Casca e folha inteira \\
\hline Cerejeira & Prunus sp & Casca \\
\hline Castanheiro-da-Índia & Aesculus hippocastaneum & Folhas \\
\hline Erva-de-passarinho & Várias espécies & Toda a planta \\
\hline Erva-mate & Ilex paraguariensis & Folhas \\
\hline Picão & Bidens pilosa & Toda a planta \\
\hline \multicolumn{3}{|c|}{ Preto } \\
\hline Caparosa & Ludwigia caparosa & Casca \\
\hline Murici-da-mata & Byrsonima crispa & Casca \\
\hline Tinteira & Coccoloba excelsa & Galhos \\
\hline
\end{tabular}

Fonte: Ferreira, 1998 (modificado)

Finalmente, pretendemos por meio das técnicas de tingimento vegetal apresentadas testar, na fase prática do desenvolvimento da coleção, a possibilidade de tingimento das fibras de paina. O critério para escolha das espécies vegetais será de acordo com a cartela de cor estabelecida para a coleção e a facilidade de adquirir as plantas. 


\subsection{Tendências de moda e design}

Tudo que se dissemina viralmente na sociedade humana tem sua origem na intimidade do ser e nunca nas circunstâncias externas e objetivas. Quando uma moda pega, quando uma frase gruda, quando uma música se arraiga imediatamente na consciência humana e se espalha como fogo na palha seca, isso só pode acontecer porque a circunstância objetiva é fiel representação de um movimento invisível que surge do interior, da intimidade do ser (OSCAR QUIROGA, A DISSEMINAÇÃO, 18 outubro, 2011).

O intuito de realizar um levantamento sobre tendências de moda e design é mostrar como trabalhar interdisciplinarmente, levando em conta o conhecimento popular e referencias mercadológicas da moda e design, estabelecidas pela indústria. O objetivo de estabelecer essa aliança é facilitar a inserção do artesanato têxtil no mercado da moda e do design, trabalhando com referencias já difundidas no mercado global. Isto não significa impor um modo de trabalho baseado apenas em referencias meramente mercadológicas, mas mostrar como funciona o modo clássico e formal pelo qual se dá o desenvolvimento de um produto têxtil para a moda e oferecer mais uma opção de venda de produtos artesanais.

Dentre as tendências para tecidos e fibras pesquisadas nas duas últimas edições do bureaux Textile View Magazine se destacaram algumas prospecções que reafirmam este trabalho: o feito a mão, as referencias locais, as tradições.

Especificamente na última edição, de fevereiro de 2013, na seção Fibres \& Fabrics da revista há uma matéria sobre artesanato e sustentabilidade em que destacam a importância da atividade artesanal como elemento sustentável na indústria do vestuário e como difusora da singularidade de cada país. Além disso, a matéria reforça a contribuição dessa atividade na vida das comunidades que a exercem. Nela o Diretor Geral do India Apparel Export Promotion Council, Dr. Darlie Koshy, pronuncia: "O artesanato será a nova ideia de luxo. Ele se conecta com as emoções. É vital preservar e protegê-lo e efetivar seu valor comercial" (TEXTILE VIEW, 2013, p. 24, tradução nossa).

Há duas décadas Vicent-Ricard (1989) já havia prospectado assimilação do artesanato têxtil numa nova cultura, por meio da associação entre a linguagem binária da informática e das técnicas têxteis. Isso pode ser conferido no trecho que citamos abaixo, retirado do capitulo "Do artesanato à informática e à robótica ... um ritmo milenar", onde o autor faz leituras visionarias e interessantes da "sociedade têxtil contemporânea" (VICENT-RICARD, 1989). 
Ao examinar a linguagem do tecido, observamos que havia nas tecnologias da informática a mesma cadência (compasso/ ritmo) já contida na criação têxtil ritmo que prossegue sem interrupção da Pré-História à atualidade, desde que surgiu a arte de fazer cestos. A combinação binária do cruzamento do fio reflete o código binário do instrumento informático [...] a assimilação desse ritmo binário pode ser considerada a base de uma nova cultura que integre em um mesmo movimento a bulimia dos gestos agitados e os remansos atentos onde se geram lentas interrogações. É nesse movimento que a nova geração parece encontrar-se (VICENT-RICARD, 1989, p. 192).

Segundo o autor o advento das tecnologias de ponta, com a informática e a robótica, levantou a suspeita de que as técnicas ancestrais chegariam ao fim, porém, ao contrário do que se imaginava "surge na nova sociedade uma assimilação inovadora entre as tecnologias de ponta e os conhecimentos artesanais" (VICENT-RICARD, 1989, p. 192). Assim, nos parece que o ritmo acelerado de consumo e das relações humanas, desencadeado pelo processo de industrialização e típico do sistema da moda tem um outro lado que se mostra cada vez mais evidente. Como é observado pela antropóloga Rita Alves num artigo onde discute o consumo, a obsolescência e os relacionamentos humanos na sociedade ocidental contemporânea, embora por um lado exista hoje um quadro de consumo exacerbado e laços frágeis de relacionamento, por outro difunde-se pelo mundo movimentos que questionam a velocidade e a descartabilidade das mercadorias e relações e buscam o retorno às práticas desaceleradas (ALVES, 2013). Ao avaliarmos o conteúdo de algumas revistas e blogs nacionais e internacionais, percebemos que, dentro de um cenário predominantemente urbano, aliado à velocidade da comunicação e das tecnologias essas práticas ganham cada vez mais espaço e aceitação e estão basicamente embasadas na valorização do ambiente e rotina doméstica, do belo nas coisas singelas, dos laços familiares e de amizade, da saúde e bem estar.

Em uma pesquisa feita no Alexa, principal fornecedor aberto de métricas globais de web, levantamos o ranking ${ }^{6}$ de weblogs mais visitados na categoria design ${ }^{7}$. Visitamos os três primeiros colocados: Treehugger (http://www.treehugger.com), design you trust (http://designyoutrust.com) e Cool Hunting (http://www.coolhunting.com); cada um dentro da sua proposta específica, mostra tendências particulares de gosto, comportamento e

\footnotetext{
${ }^{6}$ Segundo o Alexa, o rank é calculado usando a combinação da media diária de visitantes ao site e das visualizações feitas nos últimos três meses.

${ }^{7}$ A categoria design foi escolhida são mais abrangentes e em geral condensam vários assuntos que compõem o estilo de vida: moda, culinária, arte, cultura, lazer, e alguns casos ciência e política.
} 
estilo de vida, porém é possível destacar tendências em comum como eco-design, artesanato, gastronomia (em muitos casos associada à saúde) e tecnologia; o estilo de vida urbano é contrastado com elementos da natureza, no design de objetos e interiores isso também é observado: o contrate entre o cinza e o cru, entre as linhas precisas e desformes, entre o lapidado e o rústico, o novo e o velho. Nas Figuras 9 a 13 é possível verificar alguns exemplos dessas tendências observadas em revistas e weblogs de design e estilo de vida. 
Figura 9 - Tendências de estilo de vida observadas em revistas de estilo de vida

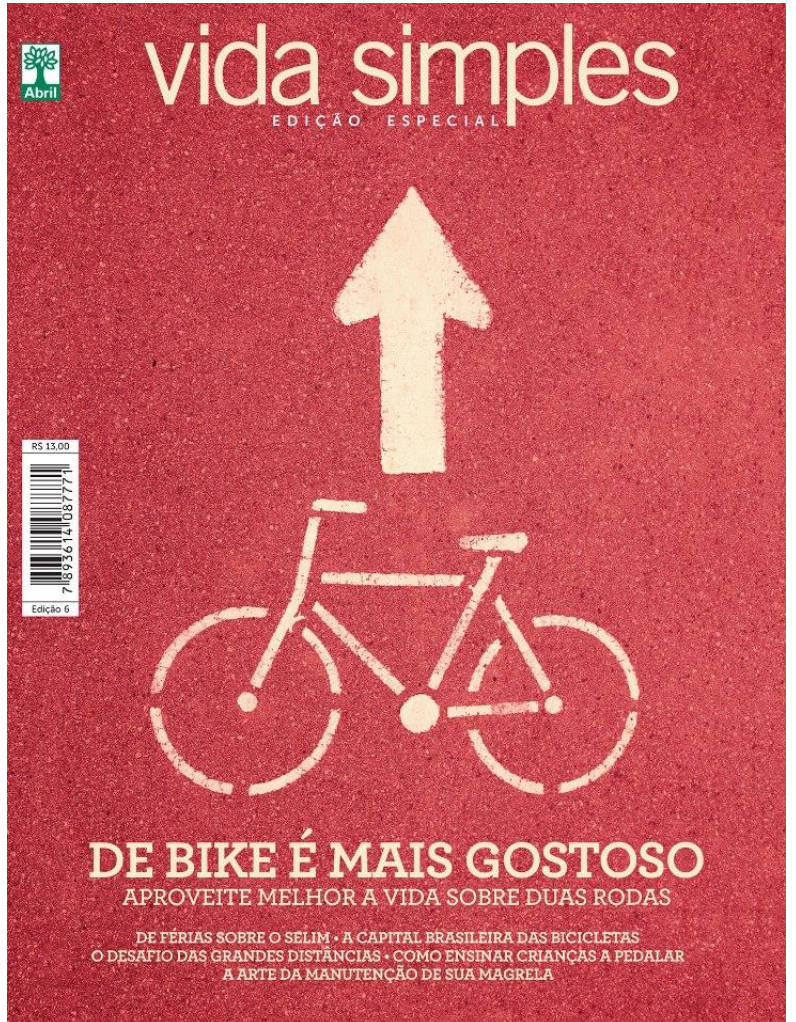

Capa da revista Vida Simples edição especial de agosto de 2012 Fonte: Revista Vida Simples, 2012

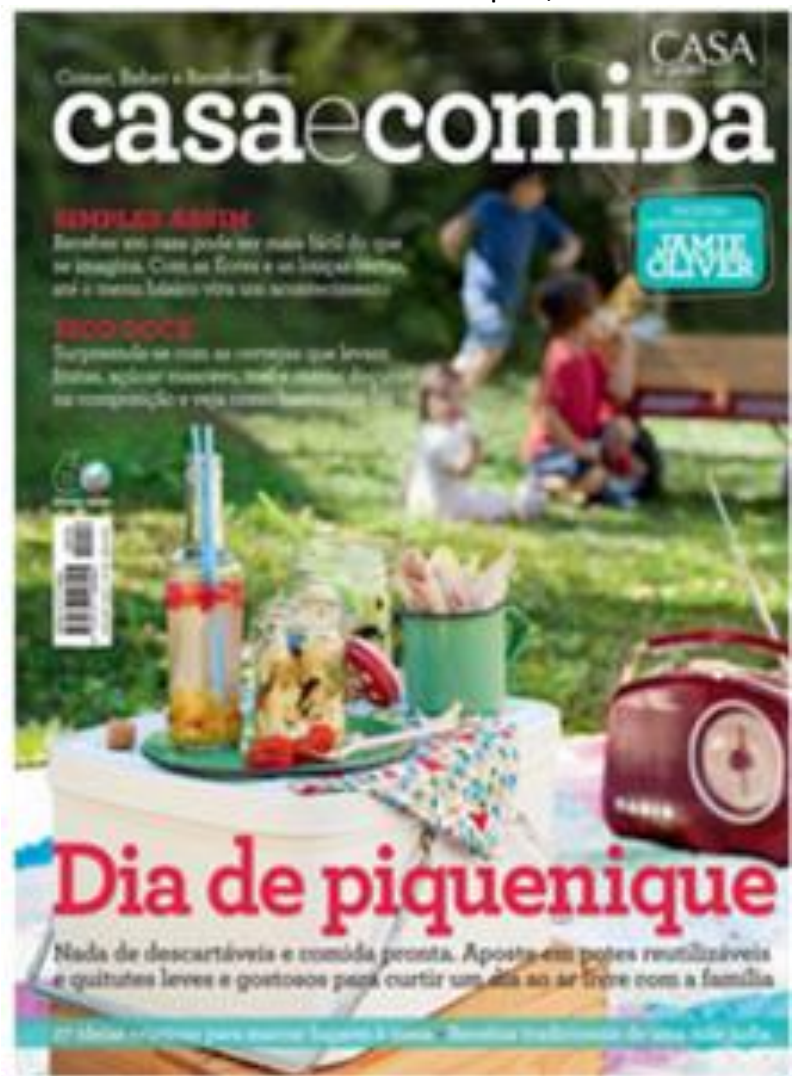

Capa da revista Casa e Comida edição de agosto/setembro de 2012 Fonte: Revista Casa e Jardim, 2012 
Figura 10 - Tendências de estilo de vida observadas em weblogs de design

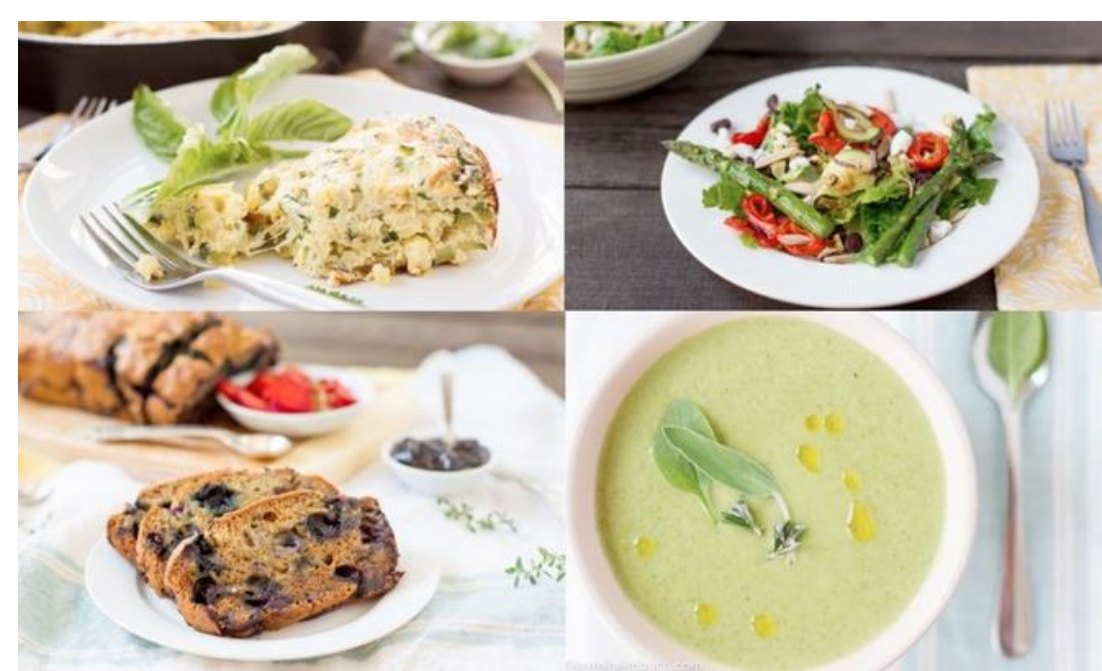

Receitas vegetarianas fáceis divulgadas no weblog Treehugger Fonte: Treehugger, 2013

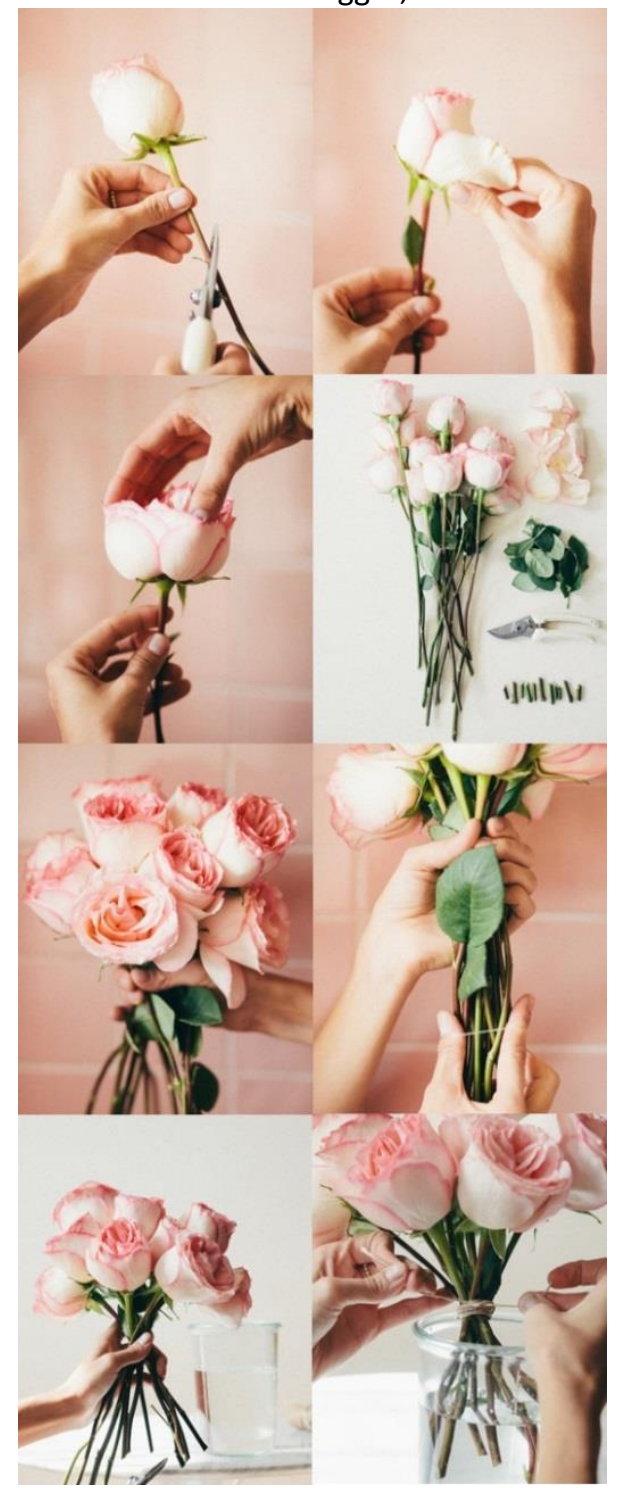

Passo a passo de arranjo de flores divulgado no weblog A cup of Jo Fonte: A cup of Jo, 2013 
Figura 11 - Tendências de estilo de vida observadas em weblogs de design

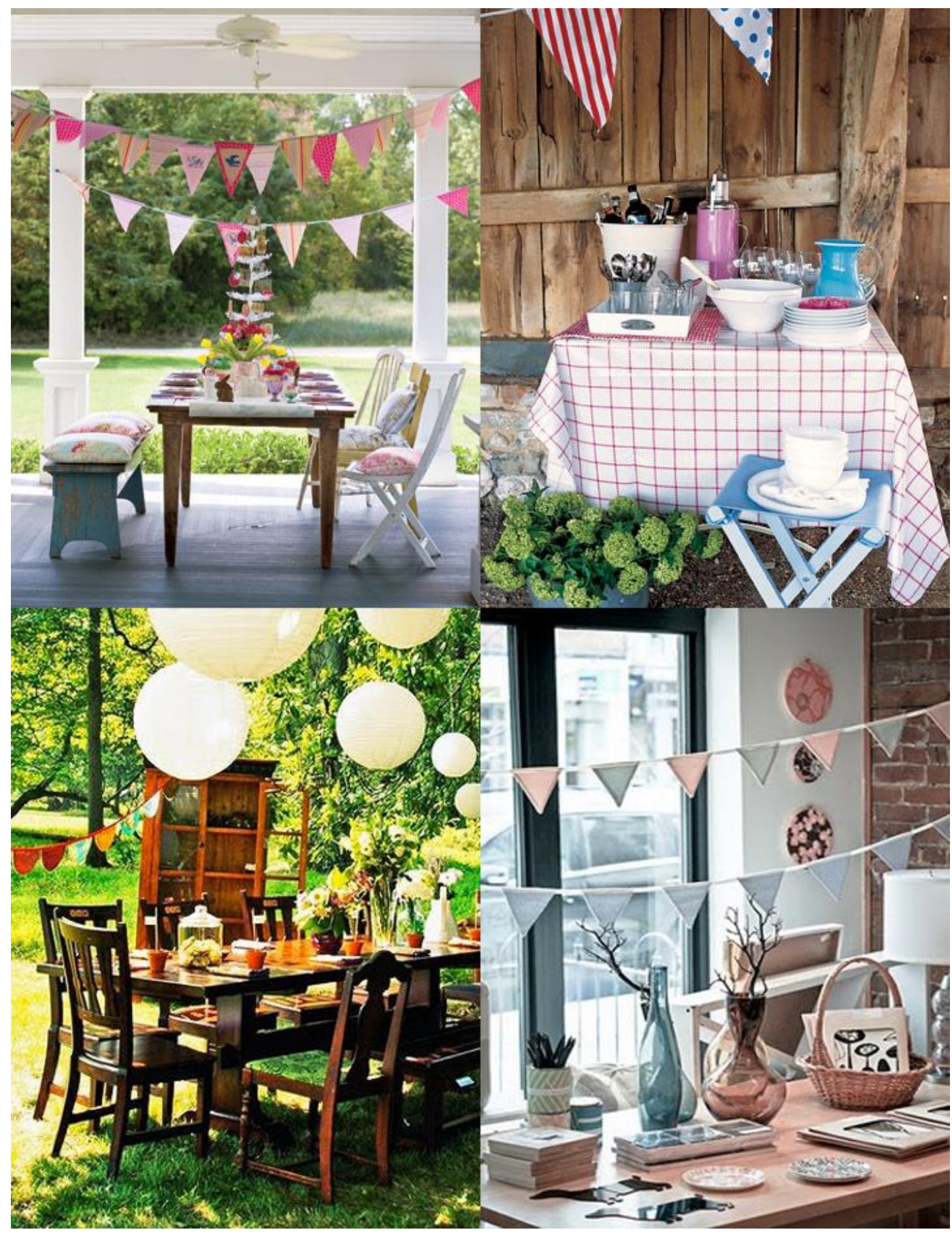

Ideias para festas em casa divulgado no weblog Petiscos

Fonte: Petiscos, 2010 
Figura 12 - Tendências de cores, materiais e formas em objetos observadas em blogs de design

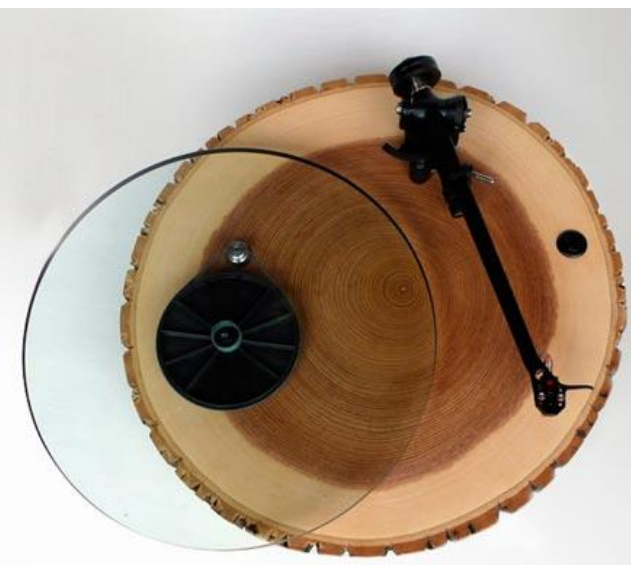

Vitrola da marca Audiowood divulgada no weblog Petiscos Fonte: Petiscos, 2013

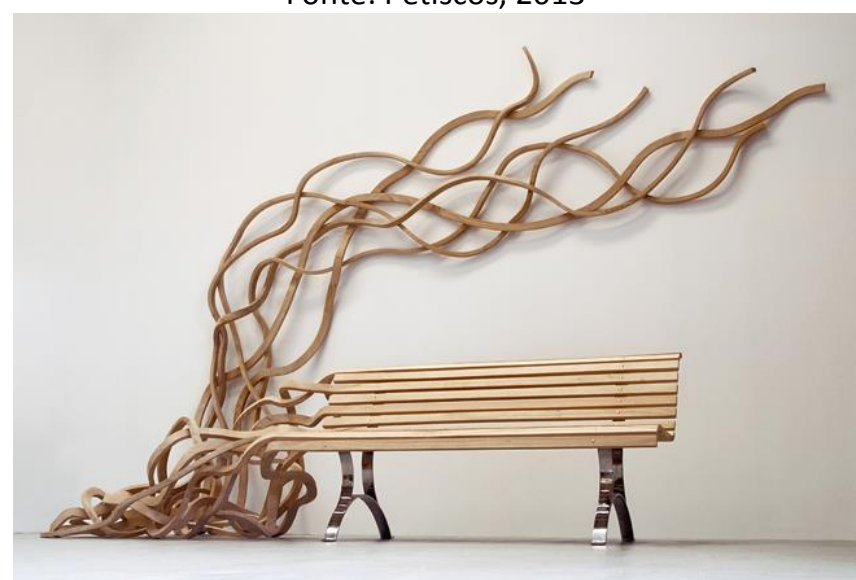

Banco do designer Pablo Reinoso divulgado no weblog Design you trust Fonte: Design you trust, 2013

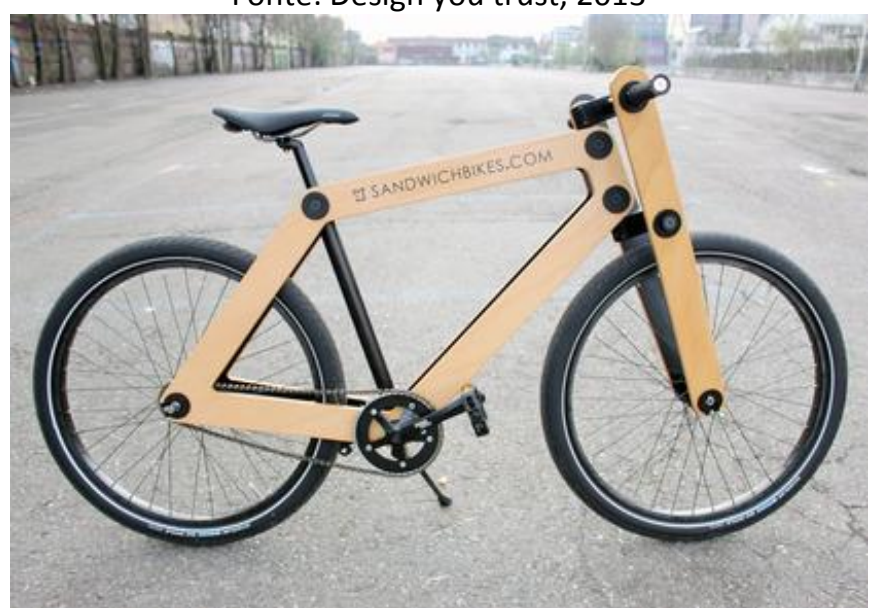

Bicicleta da marca Sandwichbikes divulgada no weblog Cool Hunting Fonte: Cool Hunting, 2013 
Figura 13 - Tendências de cores, materiais e formas em moda observadas em weblogs de design

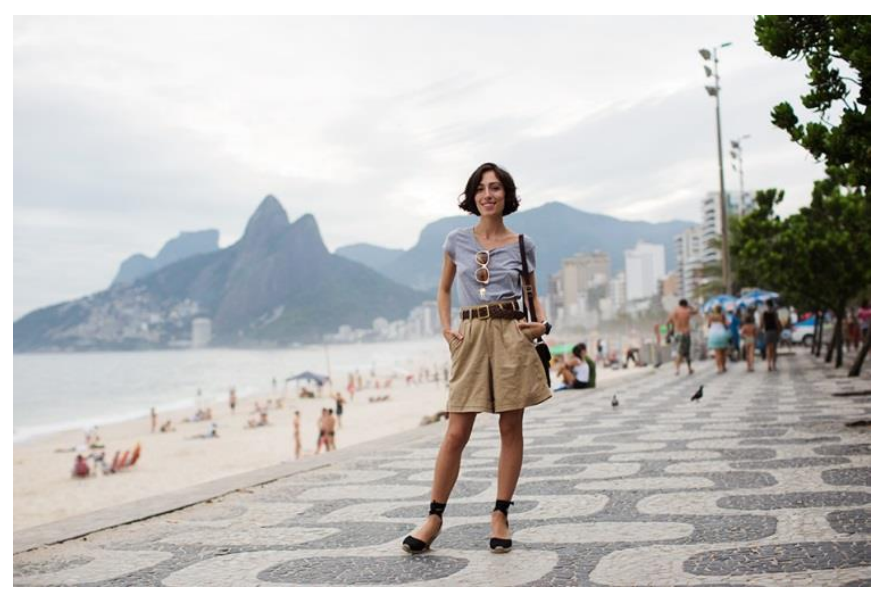

Look divulgado no weblog The Sartorialist

Fonte: The Sartorialist, 2013
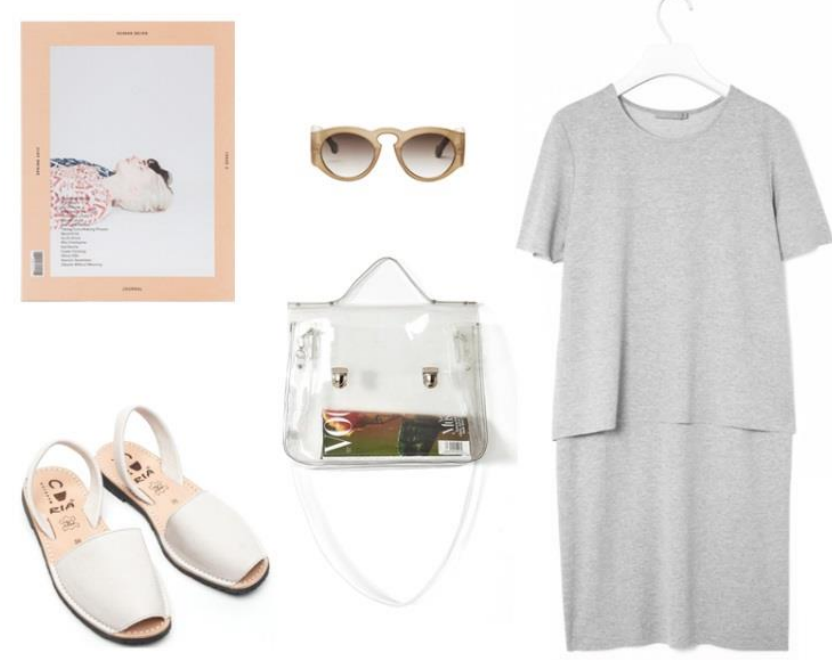

Acessórios de moda divulgados no weblog A Merry Mishap Fonte: A Merry Mishap, 2013

O trabalho desenvolvido pela estilista brasileira Flavia Aranha traduz bem esse conjunto de tendências. Presando pelo resgate do trabalho artesanal, por meio de reinvenções, a estilista desenvolve suas coleções em parceria a comunidades, com as quais troca experiências para compor suas referências. Essas comunidades desenvolvem vários tipos de matéria-prima que Flávia utiliza na produção das peças. Destacam-se as peças de algodão puro, tingidas com corantes naturais.

Na edição de setembro de 2012 da Textile View Magazine, foi publicada uma coleção de tendências de fios e malhas para o verão 2014. Na descrição da coleção a revista indica duas tendências: uma visando o futuro e o sublime, e outra de apelo ancestral. Embora essas 
duas direções pareçam opostas, elas também coexistem. Segue um trecho do conceito da coleção descrito na Textile View Magazine:

As malhas e fios, aqui, jogam com a luz e com delicadas sobreposições. Nós registramos e recriamos materiais em tecidos que são superclaros e envolvem desenvolvimentos técnicos.

Os materiais da terra também nos motivaram: os misteriosos e profundos líquidos iridescentes contrastados com substâncias de vegetais secos. Nós apreciamos o puro e inalterado o lento e o natural (TEXTILE VIEW, 2012, p. 198, tradução nossa).

Esses conceitos de coleção vão ao encontro das tendências apresentadas acima e reforça a visão de Vicent-Ricard (1989) quando pondera:

Entre o deslumbramento incondicional ante as tecnologias mais avançadas e o temeroso apego ao artesanato que testemunha a sabedoria ancestral, processa-se uma assimilação autêntica de ambas as correntes. E a moda - tanto como busca inovações em materiais têxteis quanto no tocante ao vestuário - é o ponto privilegiado da síntese criadora (VICENT-RICARD, 1989, p. 191).

Finalmente, o contexto das tendências de moda, comportamento e consumo apresentadas acima não apenas confirmam a pertinência da presente pesquisa, e dos valores dos quais a fundamentam, como balizam e se tornam fonte de inspiração para a criação do tema da coleção, que será apresentado no Capitulo 3. 


\section{Pesquisa técnico-experimental}

Nesta fase da pesquisa foi testada a possibilidade de transformar as fibras de paina e diferentes misturas destas com fibras de algodão e lã em um fio, bem como o seu tingimento, utilizando as técnicas artesanais pesquisadas na etapa anterior.

\subsection{Fiação}

Conforme mencionando no primeiro capitulo, a fibra de paina foi escolhida como matéria-prima para o desenvolvimento do projeto de coleção porque além de apresentar propriedades físicas, químicas diferenciadas com relação às demais fibras vegetais, é uma fibra fina e lisa (MEDINA, 1959), que confere um toque macio ao material, semelhante à seda. Porém, sua estrutura, dada especialmente pela superfície lisa e reta, é considerada uma limitação no processo de fiação.

A fiação se dá pela estiragem e torção de um conjunto de fibras, basicamente a estiragem é a ação que regula a finura do fio, enquanto que a torção é o fator que oferece a resistência à ele. A capacidade de fiar está diretamente relacionada à torção, ao potencial de coesão entre as fibras, isto é, a capacidade dessas aderirem, ou encaixarem umas às outras criando um atrito. Assim, fibras muito lisas como a paina são mais trabalhosas para fiar e os fios são de resistência inferior.

Uma maneira de otimizar a fiação de algumas fibras e reduzir as características que não são favoráveis é a combinação com outras fibras que tenham propriedades diferentes. Por isso, considerando que no caso da paina o limitante é a sua superfície lisa, que dificulta a sua coesão inter-fibras, além da tentativa de produzir um fio $100 \%$ paina, procuramos experimentar diferentes misturas com fibras de lã e de algodão, com o intuito de melhorar o processo de fiação. A fiação da paina com o algodão foi mencionada nos estudos sobre a tecelagem manual no Triângulo Mineiro (citar), porém, desconhecemos a mistura da paina com a lã.

Acredita-se, por meio dessas experimentações, que as propriedades morfológicas da fibra de algodão, caracterizada por uma leve torção na sua seção longitudinal (Figura 14b); ou da fibra de lã, caracterizada por escamas que atuam como garras (Figura 14a), favoreçam 
a coesão inter-fibras, tornando a fiação da paina mais simples e proporcionando um fio de maior resistência.

Figura 14 - Morfologia das fibras de algodão e lã

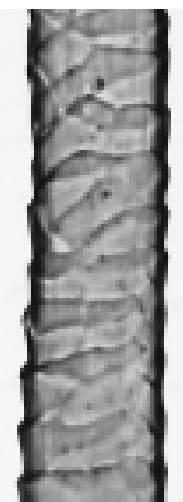

a. Vista longitudinal da fibra de lã

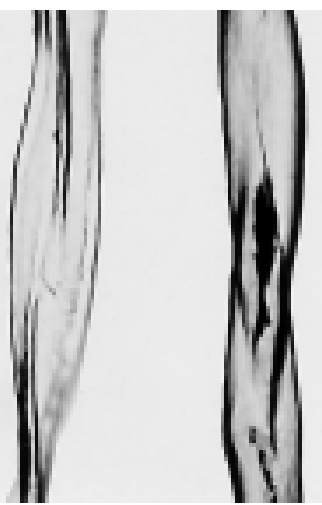

b. Vista longitudinal da fibra de algodão Fonte: American Association of Textile Chemists and Colorists - AATCC, 2012

Abaixo segue a descrição das experimentações de fiação realizadas com a paina, que teve a orientação e acompanhamento do professor de tecelagem e fiação Donizeti Speranza.

\subsubsection{Fiação da paina pura}

A paina utilizada foi coletada dos frutos de árvores da espécie Chorisia speciosa, no município de Itapetininga, nos meses de maio e junho. A coleta foi feita pelo mateiro Wladimir Corrêa.

A paina não exige preparo algum, as fibras retiradas do interior dos frutos saem praticamente limpas, e o pouco que há de impureza nas fibras é removido no processo de cardagem.

As fibras foram cardadas e levadas à roda de fiar. A fiação não é contínua, pois devido ao fato das fibras de paina serem curtas e lisas elas deslizam e o fio rompe com facilidade, devido à isso também é mais difícil controlar a espessura e regularidade do fio. 
Figura 15 - Fio de paina
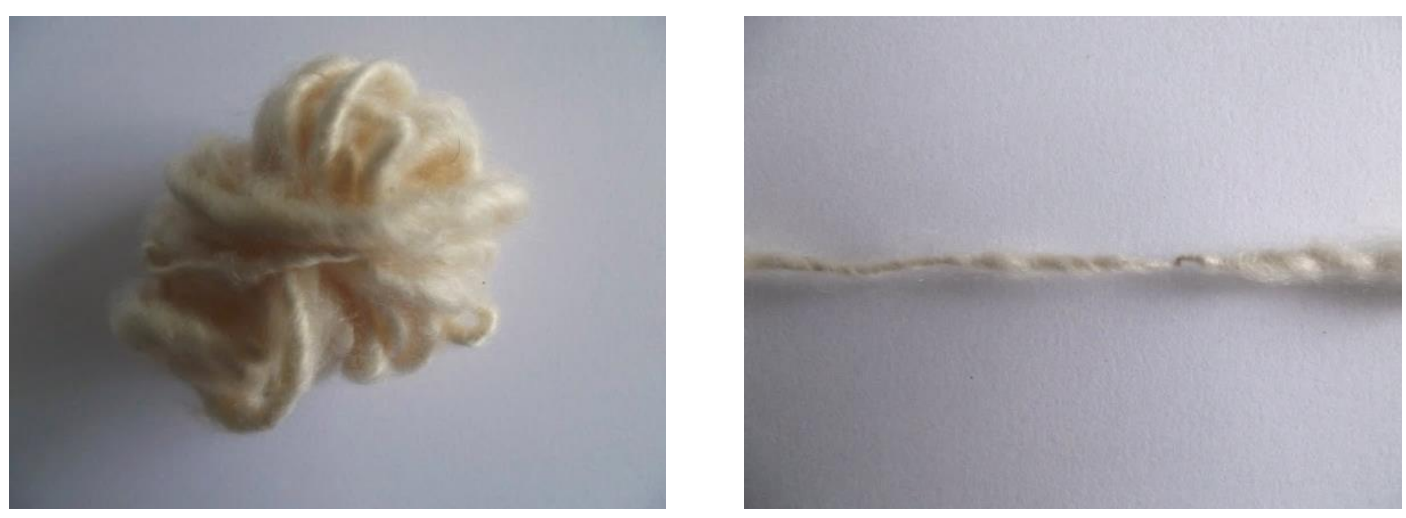

Fonte: acervo do autor

\subsubsection{Fiação da paina com lã}

A lã utilizada nessa experimentação foi fornecida por um produtor que cria carneiros em uma fazenda no município de Pinhalzinho - SP, segundo ele, os carneiros são de uma variedade de raça merina, procedente da Nova Zelândia. A lã dos carneiros de raça merina é considerada a lã de maior valor para indústria têxtil, pois são finas, de toque macio e têm um excelente rendimento (ERHARDT et al, 1976). Segundo o produtor, os carneiros que cria não são da raça merina que tem a lã de maior qualidade, porém, pudemos constatar durante a experimentação que a lã é aplicável para fiação e produz fios de boa qualidade.

\section{Preparo da lã}

Iniciamos o processo de experimentação pelo preparo da lã (Figura 16) que passou por um procedimento de triagem, em que é feita uma seleção das mechas mais longas e claras e a remoção de impurezas maiores, seguida da lavagem em água e secagem. 
Figura 16 - Procedimento de preparo da lã

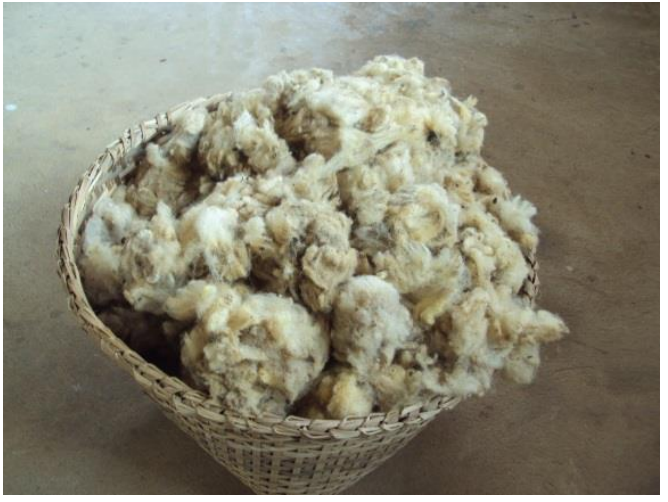

12a. Lã suja

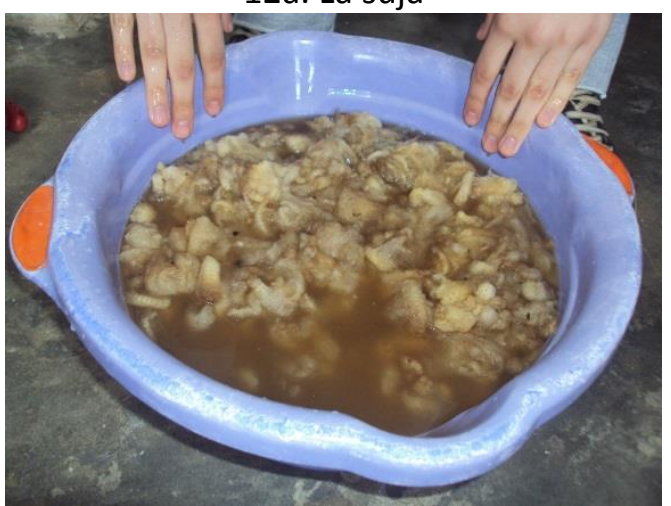

12c. Lavagem

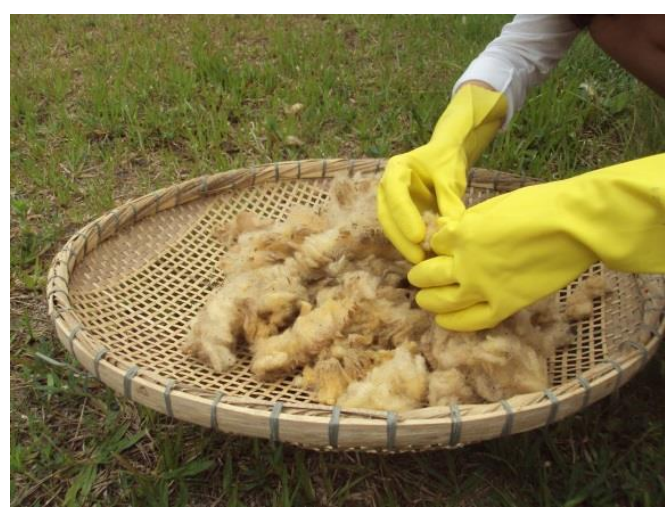

12b. Triagem

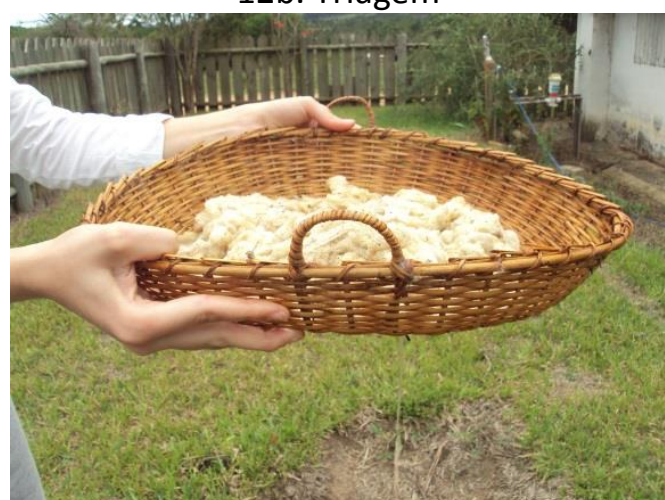

12d. Enxágue

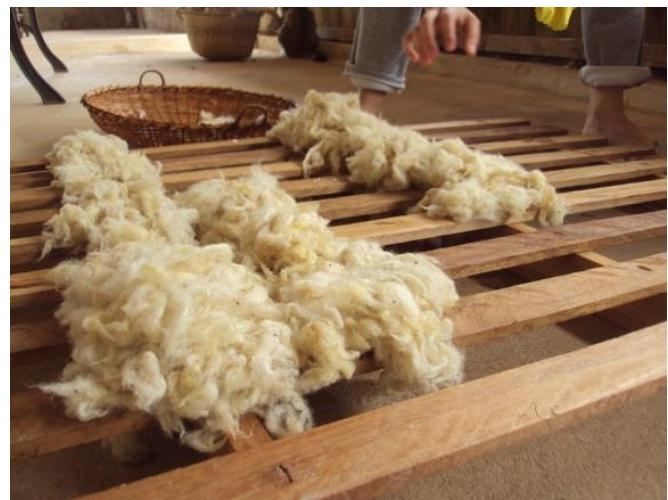

12e. Secagem

Fonte: acervo do autor

\section{Cardagem e mistura}

Após a seleção e limpeza da lã partimos para etapa de cardagem. Esta é uma das etapas do processo de fiação em que é possível fazer a mistura de fibras. Testamos algumas formas para misturar as fibras de paina e lã pelo procedimento de cardagem. O resultado foram dois tipos de pastas diferentes. 
Figura 17 - Pastas de paina e lã produzidas na cardagem

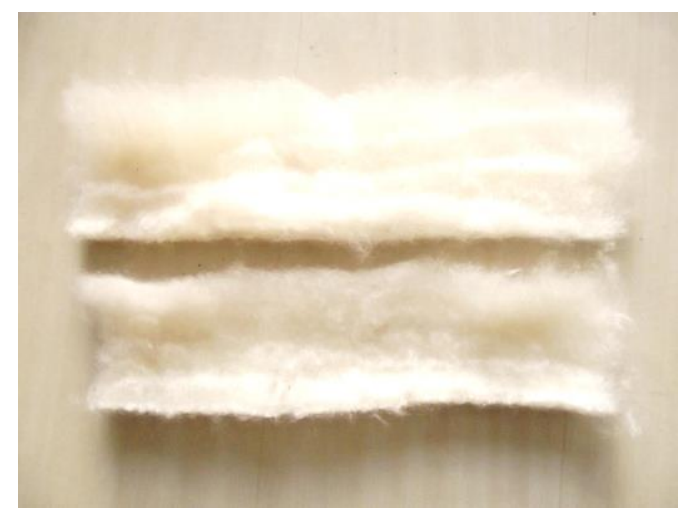

Mistura 1L (por cardagem)

$1^{\text {a }}$ camada lã; $2^{\text {a }}$ camada paina

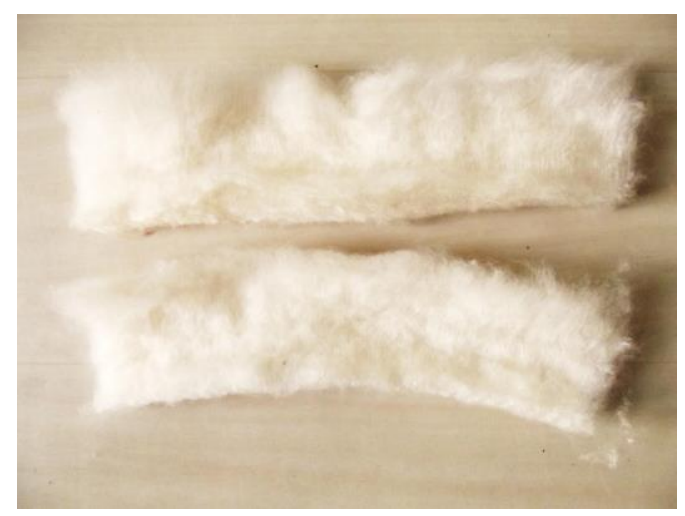

Mistura 2L (por cardagem)

$1^{\text {a }}$ camada lã, $2^{\text {a }}$ camada paina e $3^{\text {a }}$ camada lã.

Fonte: acervo do autor

Fiação

Os dois tipos de pastas montados foram levados à fiação em roda de fiar. Em todos os casos tivemos facilidade para obter uma fiação contínua e um fio relativamente regular, porém não muito homogêneo, é possível ver trechos em que predomina a lã e outros que predomina a paina. No aspecto do fio predominou o toque mais rústico da lã e um suave brilho da paina. 
Figura 18 - Fios obtidos das misturas $1 \mathrm{~L}$ e $2 \mathrm{~L}$

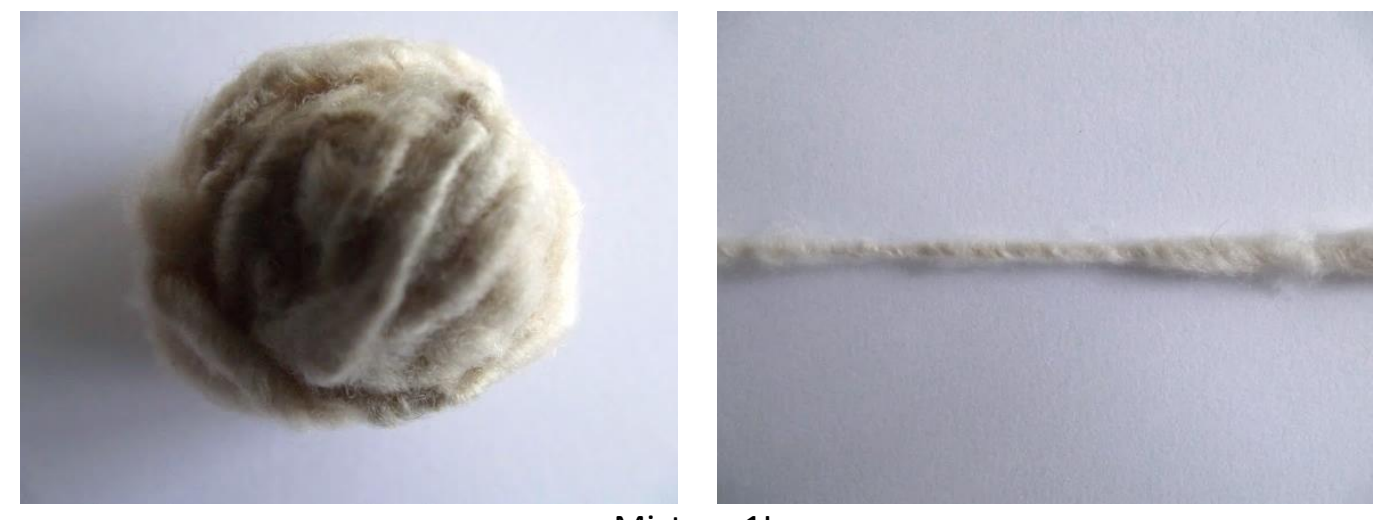

Mistura 1L

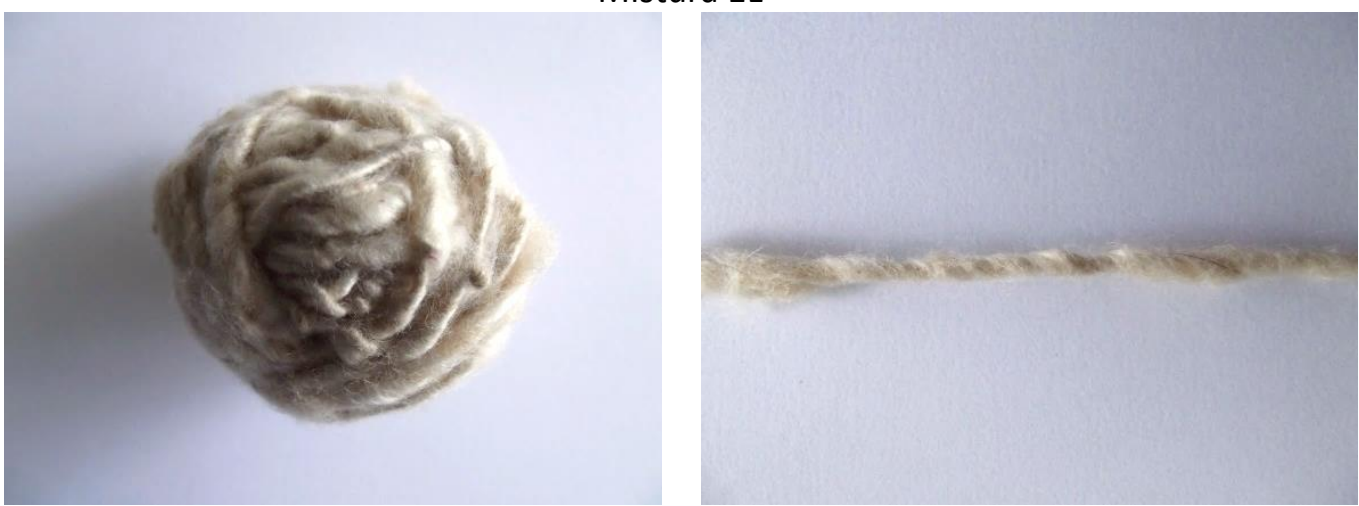

Mistura 2L

Fonte: acervo do autor

Nesta etapa foram testados mais dois tipos de mistura. A primeira (mistura $3 \mathrm{~L}$ ) foi a fiação com duas pastas puras: uma pasta de lã e uma pasta de paina são dispostas paralelamente e passam pela roda de fiar simultaneamente; a segunda (mistura $4 \mathrm{~L}$ ) foi a fiação com alma de lã: um fio de lã já pronto é retorcido, passando novamente pela roda de fiar, junto a uma pasta de paina. Na mistura 3L, não foi possível obter um fio, notamos que a adesão entre as fibras de lã e paina não é efetiva, a lã tende a torcer sobre si mesma e as fibras da paina, por serem mais curtas, tendem a ficar soltas na superfície do fio, formando nódulos. O fio obtido da mistura $4 \mathrm{~L}$ ganhou mais características visuais e tácteis da paina, mas ficou mais espesso e irregular do que os obtido das misturas $1 \mathrm{~L}, 2 \mathrm{~L}$ e $3 \mathrm{~L}$. 
Figura 19 - Fio obtido da mistura $4 \mathrm{~L}$

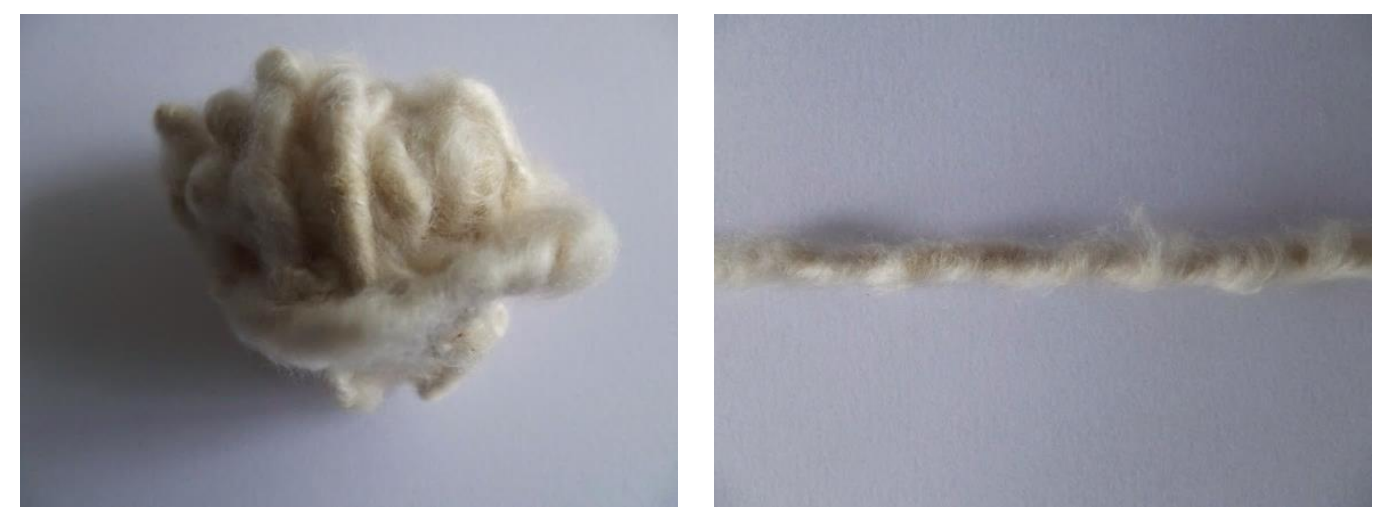

Mistura 4L

Fonte: acervo do autor

\subsubsection{Fiação da paina com algodão}

Nessa experimentação foi utilizado dois tipos de algodão: algodão cru na forma de manta (Figura 20) e algodão em forma de fibras (Figura 21). O algodão em manta é, na realidade, um produto têxtil médico-hospitalar utilizado como atadura ortopédica. Num primeiro momento ele foi selecionado por uma dificuldade de adquirir as fibras de algodão, após um primeiro teste, vimos que o algodão em forma de manta ofereceu uma vantagem, pois as fibras já estão organizadas, dispensando até a cardagem, caso ela fosse fiada pura. $\mathrm{O}$ algodão em fibra foi fornecido pelo professor Donizeti Speranza extraído de uma plantação particular, num sítio no interior do estado de São Paulo. Esse algodão é de qualidade extremamente superior ao da atadura ortopédica, pois as fibras são mais claras e longas.

\section{Preparo do algodão}

O algodão na condição de manta não exigiu um preparo elaborado, apenas foi feita uma separação de camadas, para remover um acabamento da superfície que estava aplicado em uma das faces da manta. 
Figura 20 - Procedimento de preparo do algodão em manta

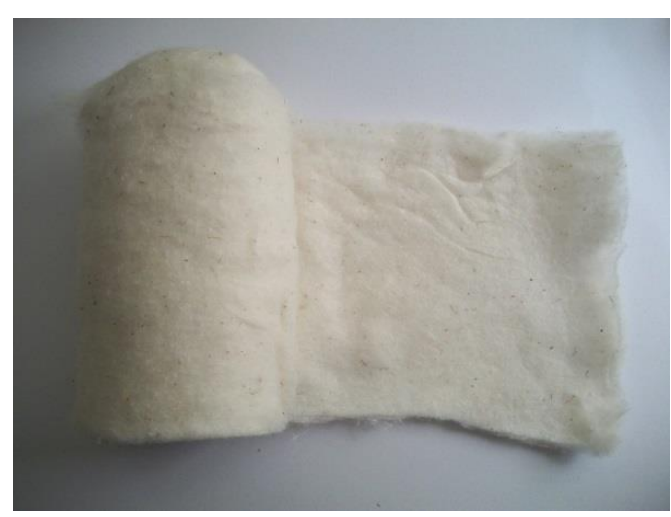

12a Manta de algodão

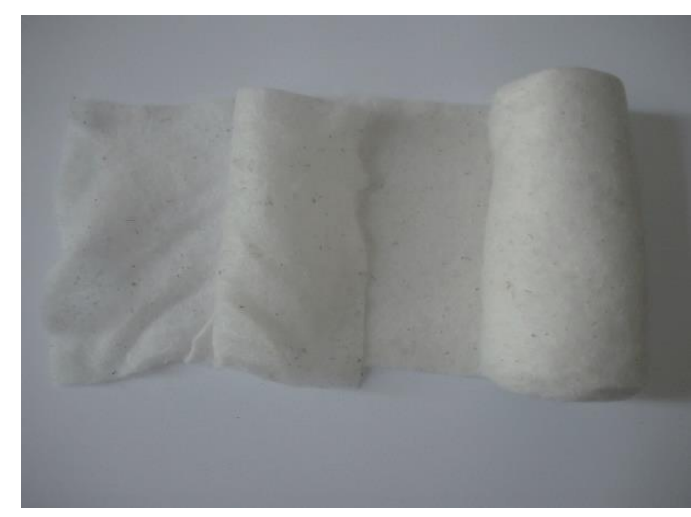

12b Remoção do acabamento

Fonte: acervo do autor

Já para o algodão em fibra e não processado, foi necessária uma primeira limpeza para remoção das sementes (descaroçar), que foi feita manualmente.

Figura 21 - Procedimento de preparo do algodão em fibra

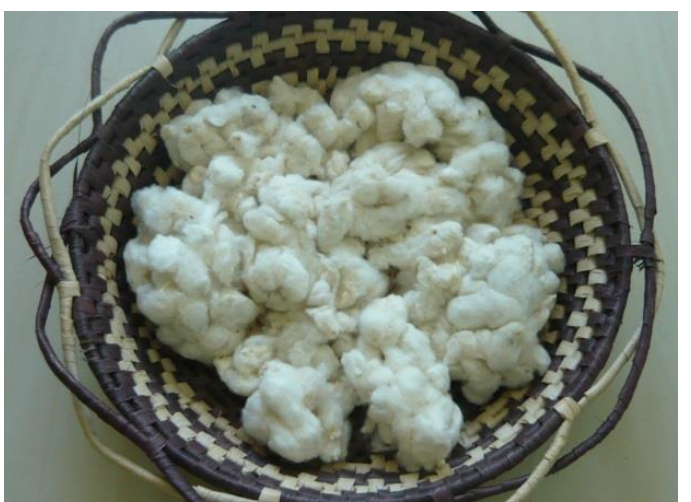

12a Manta de algodão

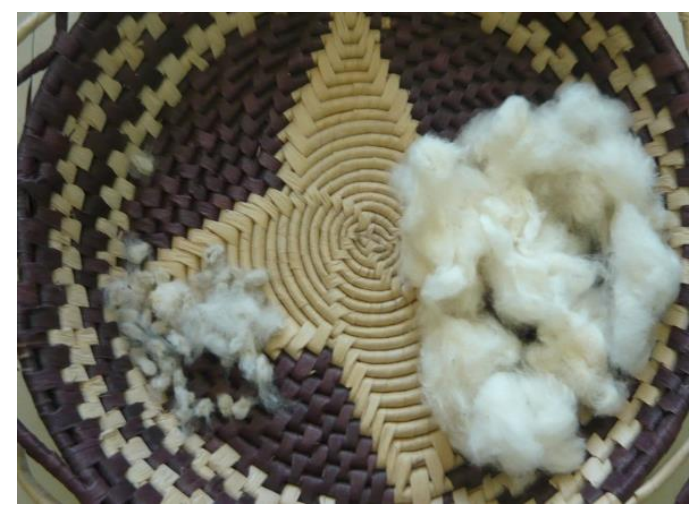

12b Remoção do acabamento

Fonte: acervo do autor

\section{Cardagem e mistura}

Assim como no processo de mistura da paina com a lã, nesta etapa testamos algumas formas para misturar as fibras de paina e algodão em manta e em fibras. Nas misturas de $1 A_{M}$ a $3 A_{M}$ utilizamos o algodão em manta e nas misturas de $1 A_{F}$ a $3 A_{F}$ utilizamos o algodão em fibra. 
Figura 22 - Pastas de paina e algodão em manta produzidas na cardagem

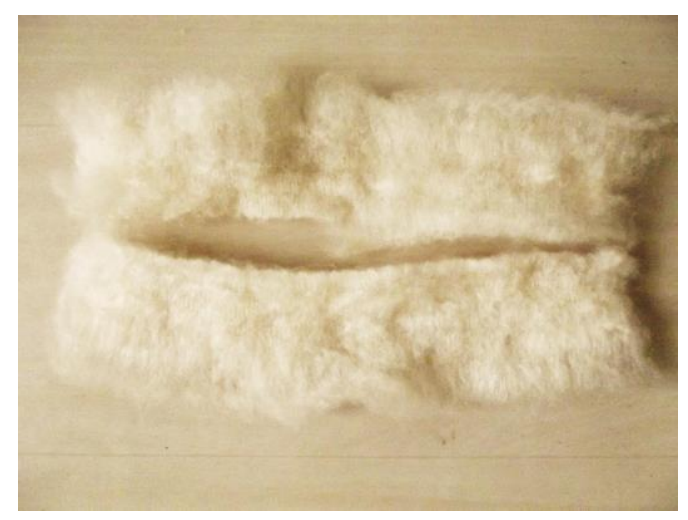

Mistura $1 \mathrm{~A}_{M}$ (por cardagem)

$1^{\text {a }}$ camada algodão; $2^{\mathrm{a}}$ camada paina

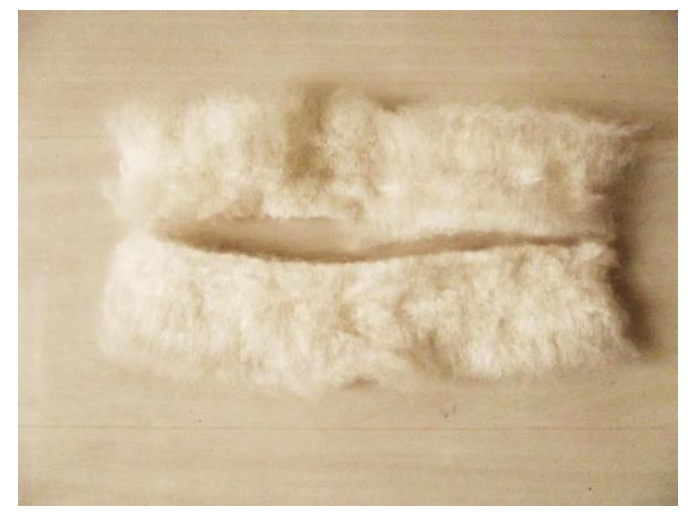

Mistura $2 \mathrm{~A}_{\mathrm{M}}$ (por cardagem)

$1^{\text {a }}$ camada algodão, $2^{\mathrm{a}}$ camada algodão e $3^{\mathrm{a}}$ camada paina.

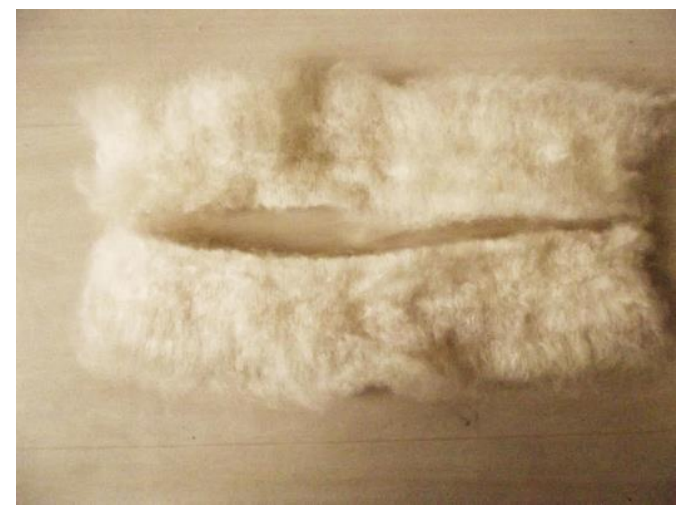

Mistura $3 \mathrm{~A}_{M}$ (por cardagem)

$1^{\text {a }}$ camada paina, $2^{\text {a }}$ camada paina e $3^{\text {a }}$ camada paina.

Fonte: acervo do autor 
Figura 23 - Pastas de paina e algodão em fibra produzidas na cardagem

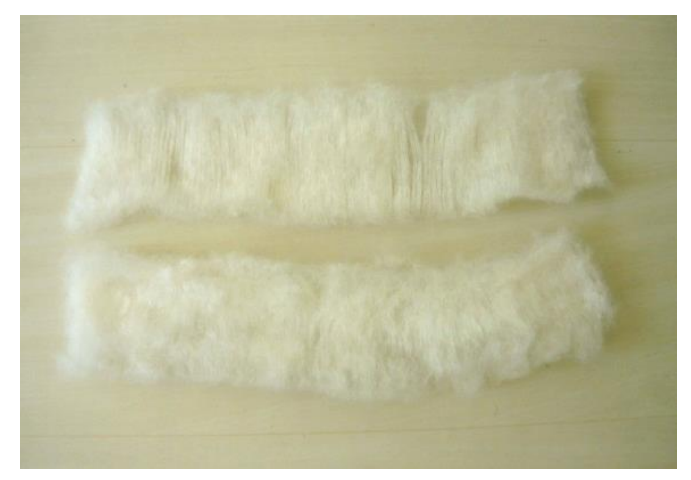

$$
\begin{aligned}
& \text { Mistura } 1 \mathrm{~A}_{F} \text { (por cardagem) } \\
& 1^{\mathrm{a}} \text { camada algodão; } 2^{\mathrm{a}} \text { camada paina }
\end{aligned}
$$

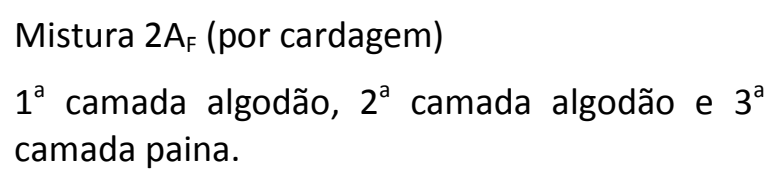

Mistura $3 \mathrm{~A}_{\mathrm{F}}$ (por cardagem)

$1^{\text {a }}$ camada paina, $2^{\text {a }}$ camada paina e $3^{\text {a }}$ camada paina.

Fonte: acervo do autor

\section{Fiação}

Os três tipos de pastas de cada tipo de algodão foram levados à fiação em roda de fiar. Em todos os casos foi possível obter uma fiação contínua. O fio obtido tem aspecto mais homogêneo que os fios obtidos pela mistura de paina e lã, já que a textura do algodão se assemelha mais com a da paina. Os fios obtidos das misturas $1 A_{M}$ a $3 A_{M}$ ficaram mais grossos e apresentaram uma regularidade mediana se comparados com os fios obtidos das misturas $1 A_{F}$ a $3 A_{F}$. Isso porque as fibras de algodão da manta são bem mais curtas e de qualidade inferior. Além disso, os fios das misturas $1 A_{F}$ a $3 A_{F}$ saíram mais finos e delicados. Notamos que a adesão entre as fibras de paina com as de algodão é melhor do que com as fibras lã. 
Quanto ao aspecto visual e táctil verificamos que o fio obtido da mistura $2 A_{M}$ não ficou tão sedoso e macio quanto os demais, já que predominou o algodão.

Figura 24 - Fios obtidos das misturas $1 A_{M}, 2 A_{M}$ e $3 A_{M}$
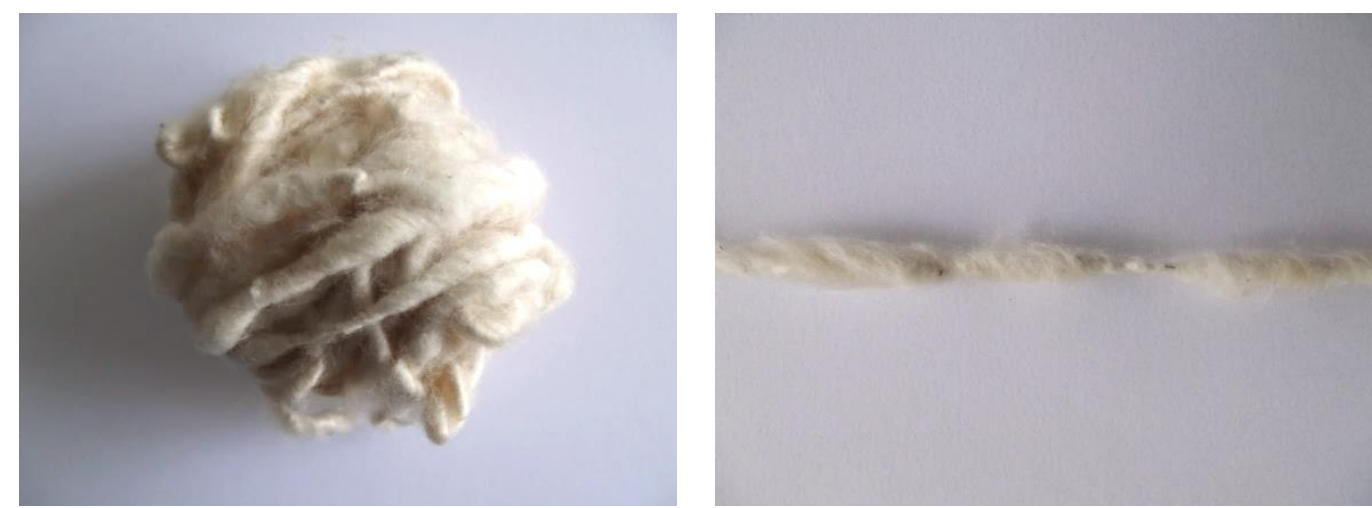

Mistura $1 A_{M}$

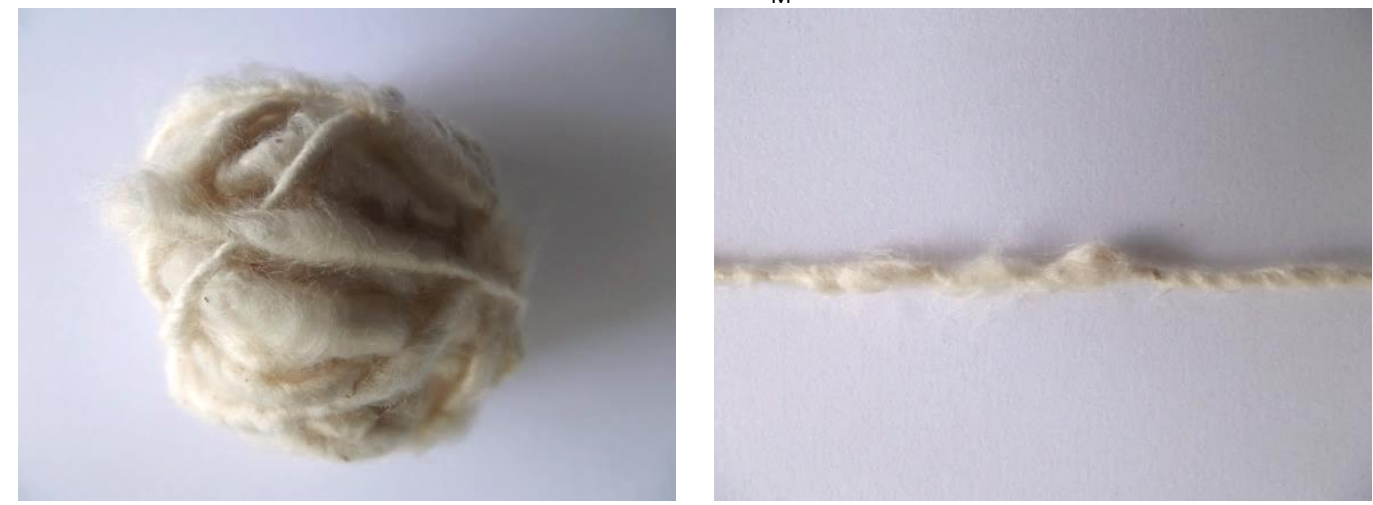

Mistura $2 \mathrm{~A}_{\mathrm{M}}$

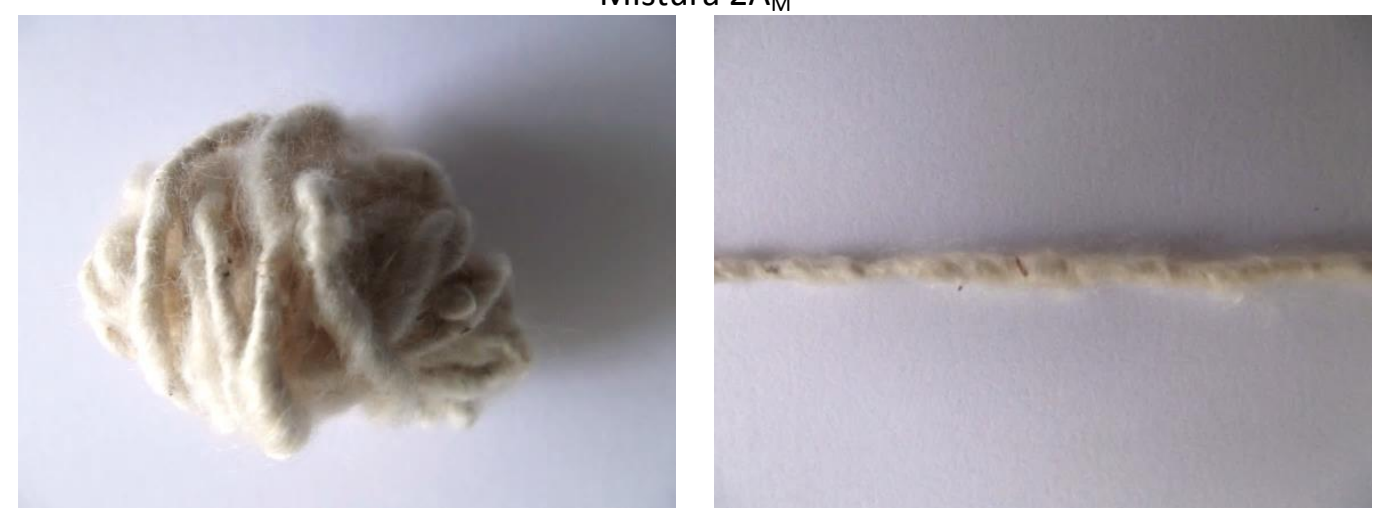

Mistura $3 \mathrm{~A}_{\mathrm{M}}$

Fonte: acervo do autor 
Figura 25 - Fios obtidos das misturas $1 A_{F}, 2 A_{F}$ e $3 A_{F}$

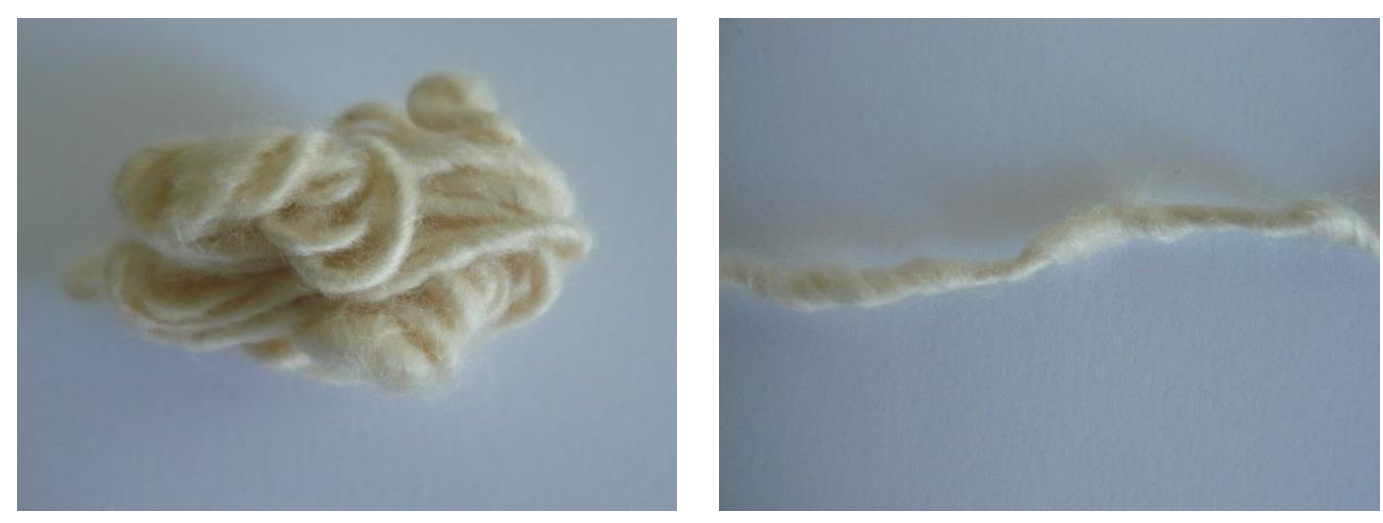

Mistura $1 \mathrm{~A}_{\mathrm{F}}$

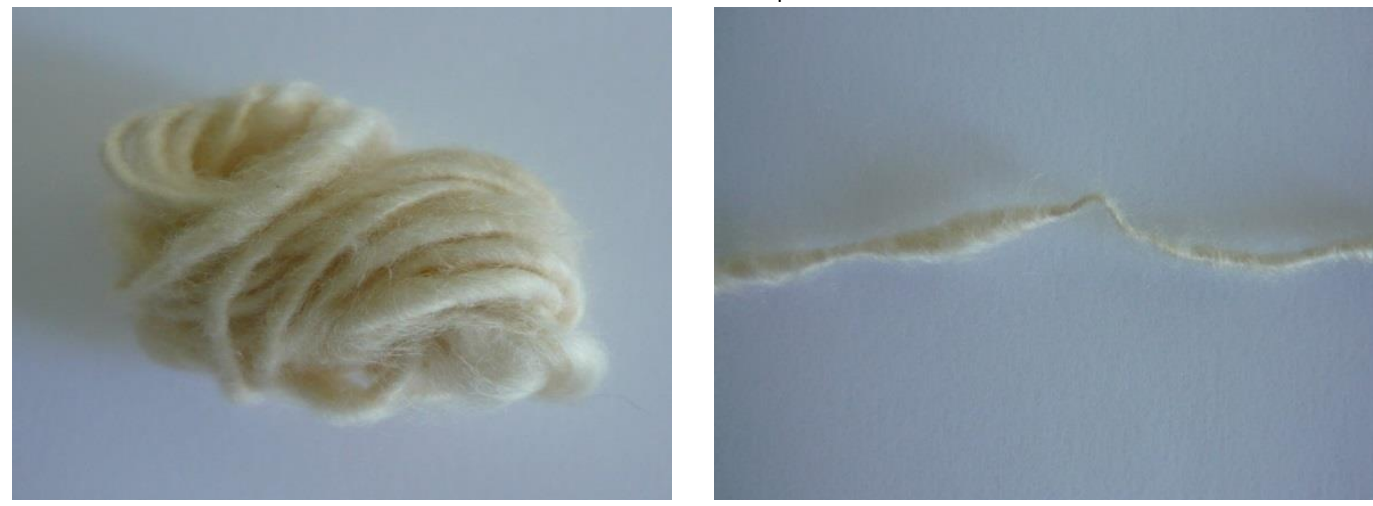

Mistura $2 \mathrm{~A}_{F}$

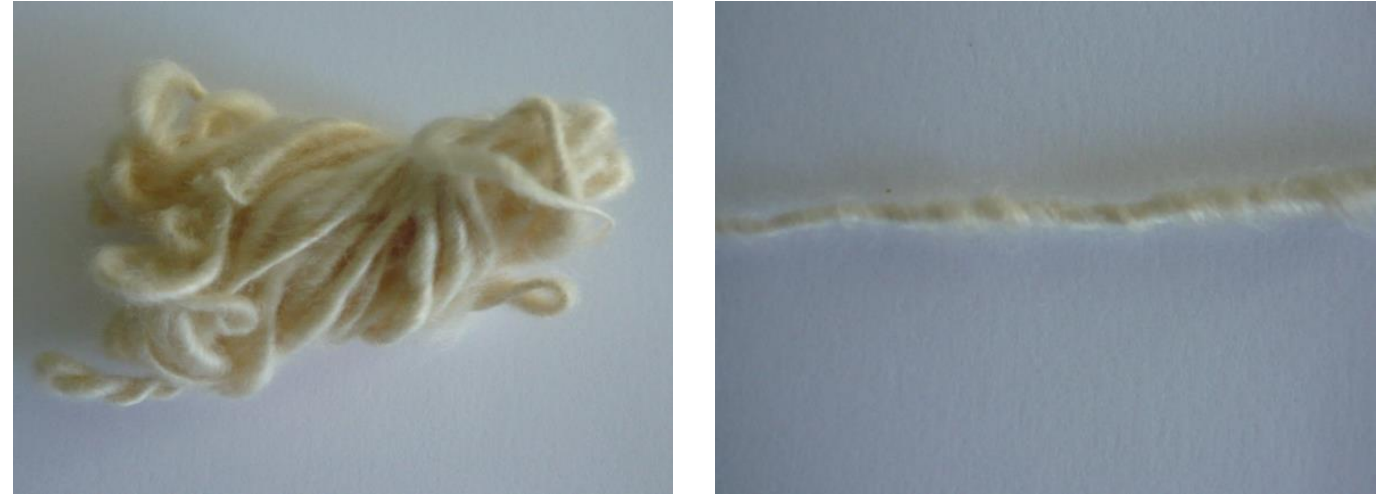

Mistura $3 A_{F}$

Fonte: acervo do autor

Na etapa de fiação também testamos mais dois tipos de mistura: fiação com duas pastas puras (mistura $4 A_{F}$ ) e fiação com alma de algodão (mistura $5 \mathrm{~A}$ ). Na mistura $4 \mathrm{~A}_{\mathrm{F}}$ utilizamos apenas o algodão em fibras (que apresentou uma fiação de melhor qualidade nas misturas por cardagem) e na mistura 5A como alma foram utilizados quatro cabos de fios singelos, já fiados industrialmente. A fiação das pastas $4 A_{F}$ não foi contínua e não foi possível obter um fio. Já o fio obtido da mistura 5A apresentou um aspecto visual e táctil bem característico da paina, já que os fios de algodão foram completamente revestidos pelas fibras de paina, além disso, o fato de os cabos da alma serem bem finos e regulares, o 
fio apresentou-se mais regular e homogêneo que os demais fios obtidos tanto pelas misturas com algodão como lã.

Figura 26 - Fio obtido da mistura $5 \mathrm{~A}$

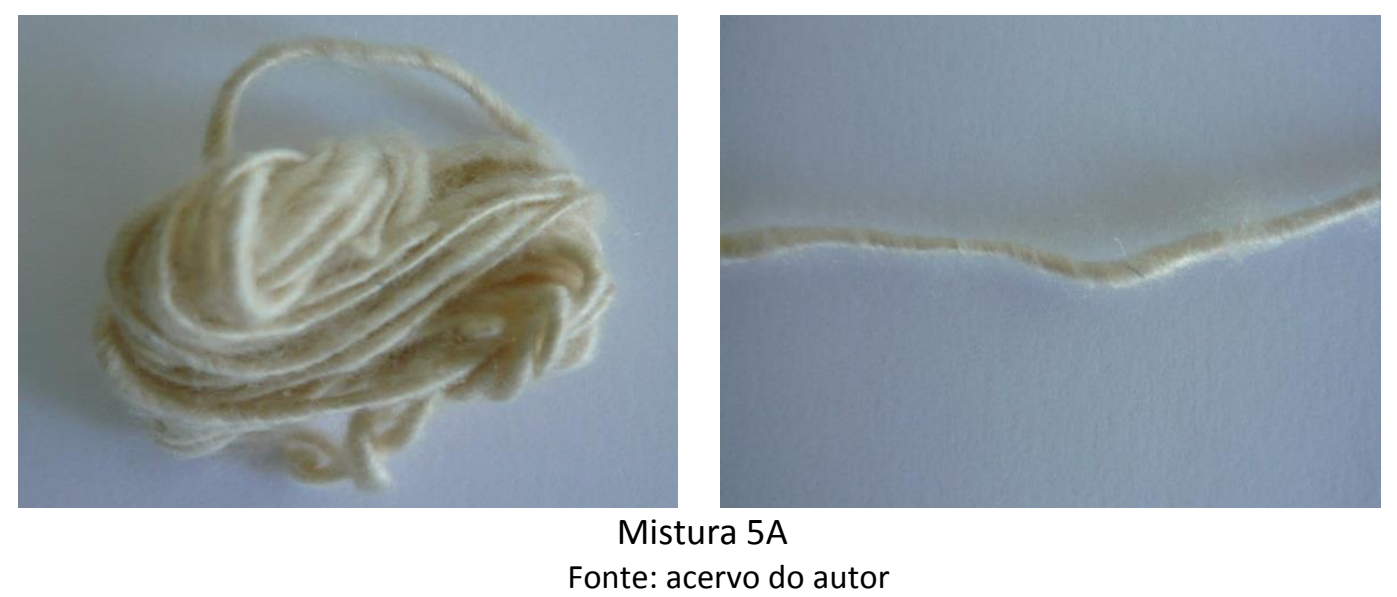

Dos experimentos de fiação realizados foi possível constatar que a fiação manual da paina pura foi inviável, pois o fio rompe com facilidade durante a própria fiação. Porém, existe ainda a possibilidade de se desenvolver em futuros trabalhos aperfeiçoamentos e adaptações da técnica e instrumentos para viabilizar sua fiação. A paina em mistura com o algodão ofereceu fios mais regulares e delicados, e valorizaram mais as características superficiais da paina do que a mistura com a lã, mas em ambos os casos uma fiação contínua foi possível. A mistura da paina com o algodão em manta ofereceu fios de qualidade inferior em relação à mistura com algodão em fibra. Devemos considerar também que nossa capacitação técnica para fiação manual pode ser aperfeiçoada a fim de desenvolver fios de mais qualidade em termos de homogeneidade (melhor distribuição das fibras) e regularidade (espessura mais regular). O uso de equipamentos de proteção individual é essencial para que seja evitada a inalação das fibras e o contato com os olhos.

\subsection{Tingimento}

A experimentação da tingibilidade das fibras de paina foi feita em escala laboratorial no Laboratório de Tecnologia Têxtil do Centro de Têxteis Técnicos e Manufaturados do Instituto de Pesquisas Tecnológicas - IPT. Foram utilizados seis corantes procedentes de espécies vegetais diferentes, pré-selecionados conforme a cartela de cor da coleção 
(apresentada no Capítulo 3). As espécies utilizadas e demais características são apresentadas tabela na abaixo.

Tabela 3 - Plantas utilizadas no tingimento

\begin{tabular}{|c|c|c|c|}
\hline Nome vulgar & Nome científico & Parte da planta & Cor \\
\hline Espinafre & Spinacea oleracea & Folhas e caule & Verde \\
\hline Erva-mate & Ilex paraguariensis & Folhas & Verde / Cinza \\
\hline Barbatimão & $\begin{array}{c}\text { Stryphnodendron } \\
\text { barbatiman }\end{array}$ & Casca & Marrom avermelhado \\
\hline Picão & Bidens pilosa & Toda a planta & Caqui / Amarelo \\
\hline Pinus & Pinus elliotti & Pinha & Castanho \\
\hline Mangueira & Mangifera $s p$ & Casca & Amarelo / Verde \\
\hline
\end{tabular}

O procedimento de tingimento foi principalmente baseado nas receitas sugeridas no Guia Prático de Tingimento com Plantas, de Eber Ferreira (1998), porém, em alguns casos foram feitas algumas modificações conforme a disponibilidade de alguns instrumentos e insumos e conforme o resultado de algumas experimentações. Segundo Ferreira (1998) o tipo de recipiente e água utilizados no tingimento, podem influenciar nas cores e fixação dos corantes, favorecendo, ou desfavorecendo a obtenção de certas tonalidades, por isso, nesta etapa de experimentação os tingimentos foram realizados em vidraria de laboratório e com água deionizada, a fim de evitar quaisquer alterações na cor original do corante. Além disso, em função da dificuldade em adquirir alguns reagentes químicos indicados nas receitas, como mordente ${ }^{8}$ foi utilizada a pedra-ume (alúmen de potássio), facilmente encontrada nas farmácias e utilizada como produto alternativo à decoada pelas artesãs de Hidrolândia Goiás (GARCIA, 1981). Como desconhecemos o comportamento da paina ao tingimento natural com as plantas relacionadas, para controlar a qualidade e efetividade dos banhos de tingimento um tecido-testemunha multifibra padrão (Figura 27), geralmente utilizado em ensaios de solidez da cor de têxteis, foi levado ao tingimento junto às fibras de paina, assim, caso nenhuma das fibras do tecido padrão não apresente um bom tingimento é possível

\footnotetext{
${ }^{8}$ Elemento de fixação utilizado no processo de tingimento que constitui em uma substância solúvel em água quente, capaz de associar-se às fibras e ao corante, tornando o corante insolúvel em água (FERREIRA, 1998).
} 
identificar se o banho não foi preparado corretamente. Abaixo segue a descrição detalhada dos experimentos de tingimento com cada planta.

Figura 27 - Tecido-testemunha multifibra utilizado para controlar o tingimento

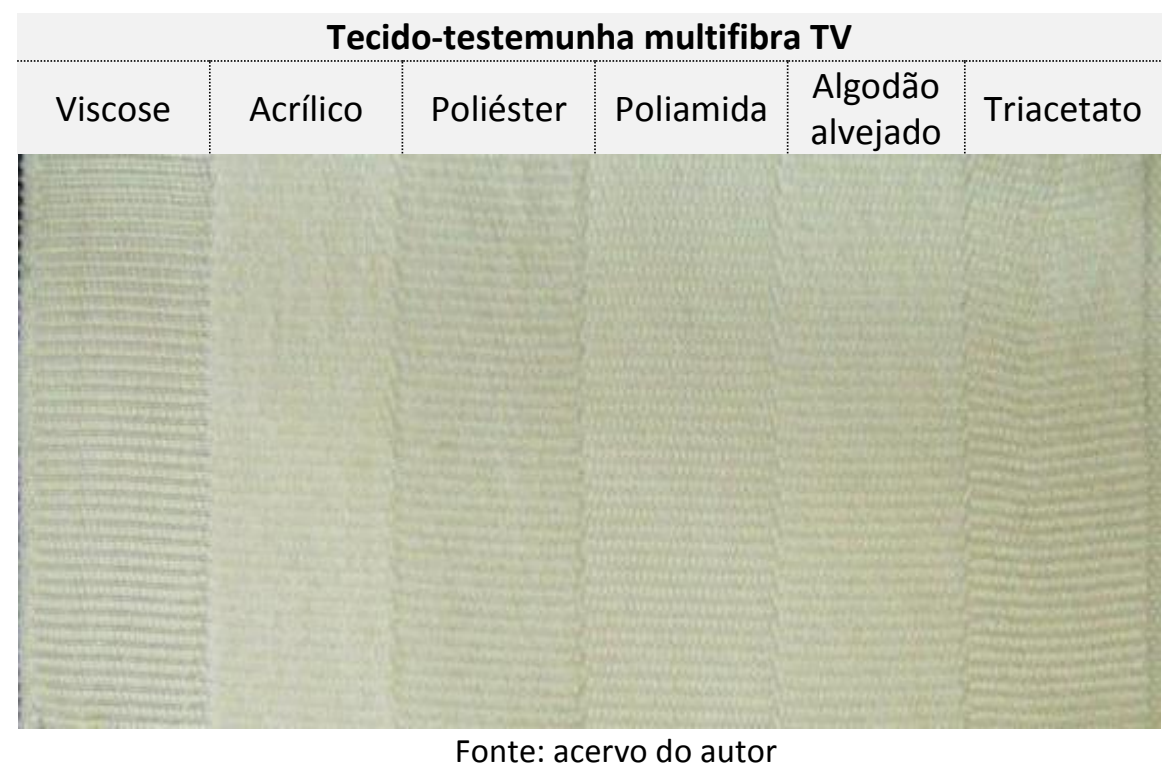

\subsubsection{Barbatimão}

Planta arbórea com grande incidência no cerrado brasileiro. A parte do barbatimão que se extrai o corante é a casca do tronco. A casca do barbatimão é bastante conhecida pelo seu alto teor de tanino e é utilizada no processo de curtume do couro (FERREIRA, 1998). Devido à presença do tanino o barbatimão não exige uso de produto auxiliar para sua fixação e inclusive pode ser utilizado como mordente para tingimentos com outras plantas. As cascas utilizadas nesse experimento (Figura 29) foram retiradas em uma chácara em Itapetininga, interior do Estado de São Paulo. A Figura 28 a seguir apresenta a receita usada como referência para o tingimento. 
Figura 28 - Receita de tingimento com o barbatimão

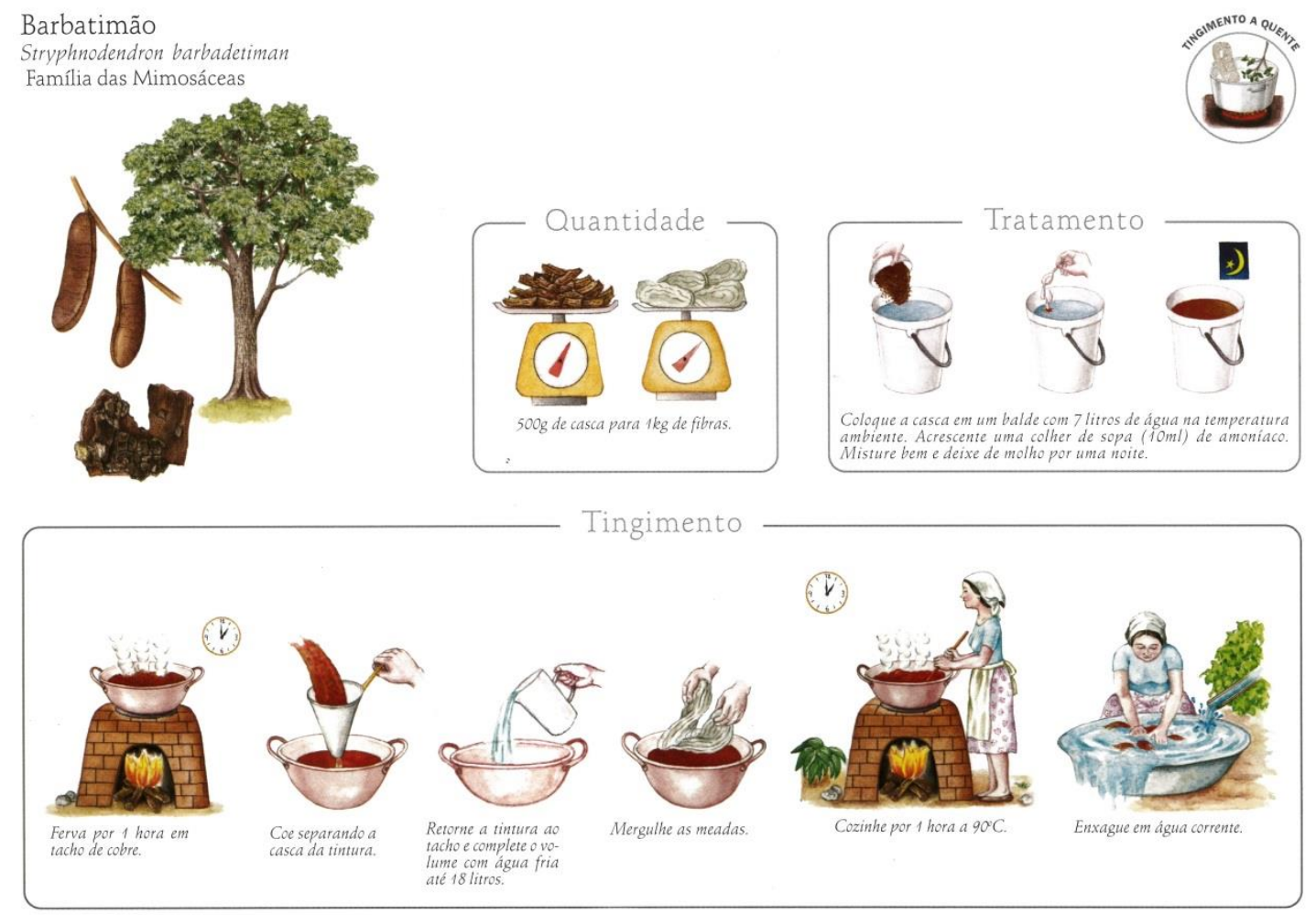

Fonte: Ferreira, 1998

\section{Extração do corante}

$10 \mathrm{~g}$ de casca de barbatimão foram acrescentados a uma solução de $140 \mathrm{~mL}$ de água e 0,5 $\mathrm{mL}$ de amoníaco. Após permanecer de molho por um dia o extrato foi levado ao fogo por 1 hora e depois coado.

Figura 29 - Cascas e extrato do barbatimão

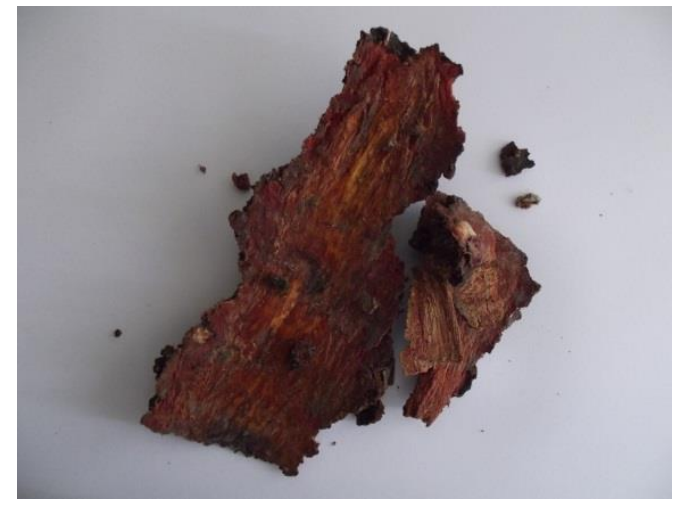

Cascas do barbatimão

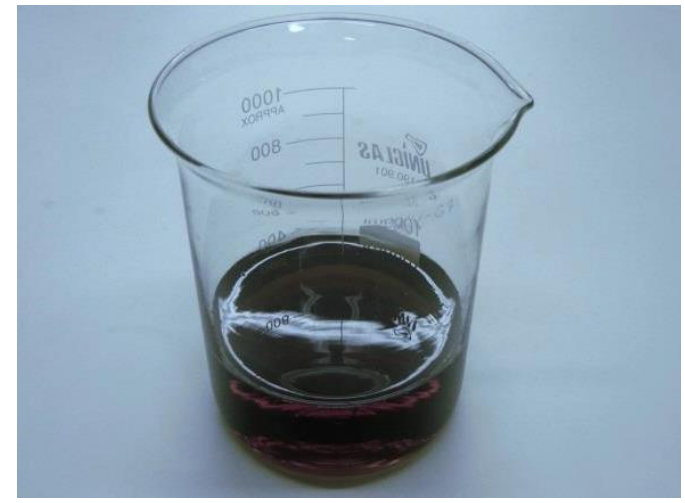

Extrato

Fonte: acervo do autor 


\section{Tingimento}

Ao extrato coado foram acrescentados mais $360 \mathrm{~mL}$ de água. As fibras de paina e o tecido-testemunha ficaram imersos no banho por $1 \mathrm{~h}$ a $(90 \pm 5){ }^{\circ} \mathrm{C}$. Após tingimento foi feito enxágue em água à temperatura ambiente.

Tanto nas fibras de paina quanto no tecido-testemunha foi obtida uma cor marrom clara rosada. Na Figura 30 é possível verificar o resultado do tingimento com o barbatimão.

Figura 30 - Tingimento das fibras de paina com barbatimão

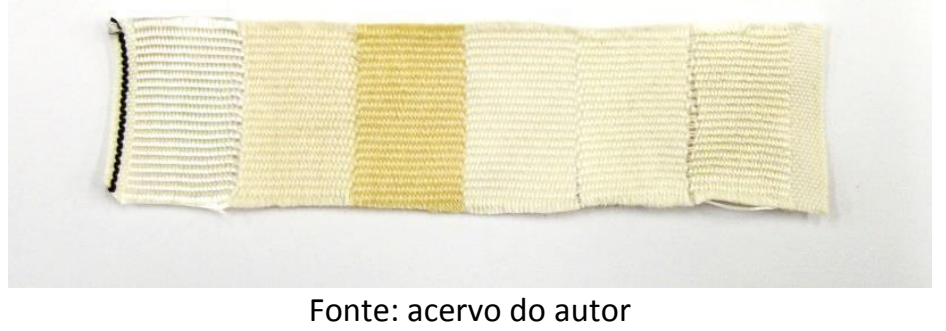

Por ter sido mencionada a ausência de necessidade do uso de mordente no tingimento, o resultado esperado era que a cor obtida fosse mais intensa e escura. Porém, num experimento de tingimento realizado com o barbatimão por Damasceno et al (2010), é mencionado que tonalidades mais intensas podem ser adquiridas após sucessivos tingimentos.

\subsubsection{Pinus}

Planta arbórea cultivada de grande importância comercial, seus principais produtos são a celulose, a madeira e a resina. Segundo Ferreira (1998) o corante é extraído das pinhas. As pinhas utilizadas nesse experimento (Figura 32 - Pinhas e extrato do pinus) foram coletadas em uma chácara em Itapetininga, interior do Estado de São Paulo. A Figura 31 a seguir apresenta a receita usada como referência para o tingimento. 
Figura 31 - Receita de tingimento com o pinus

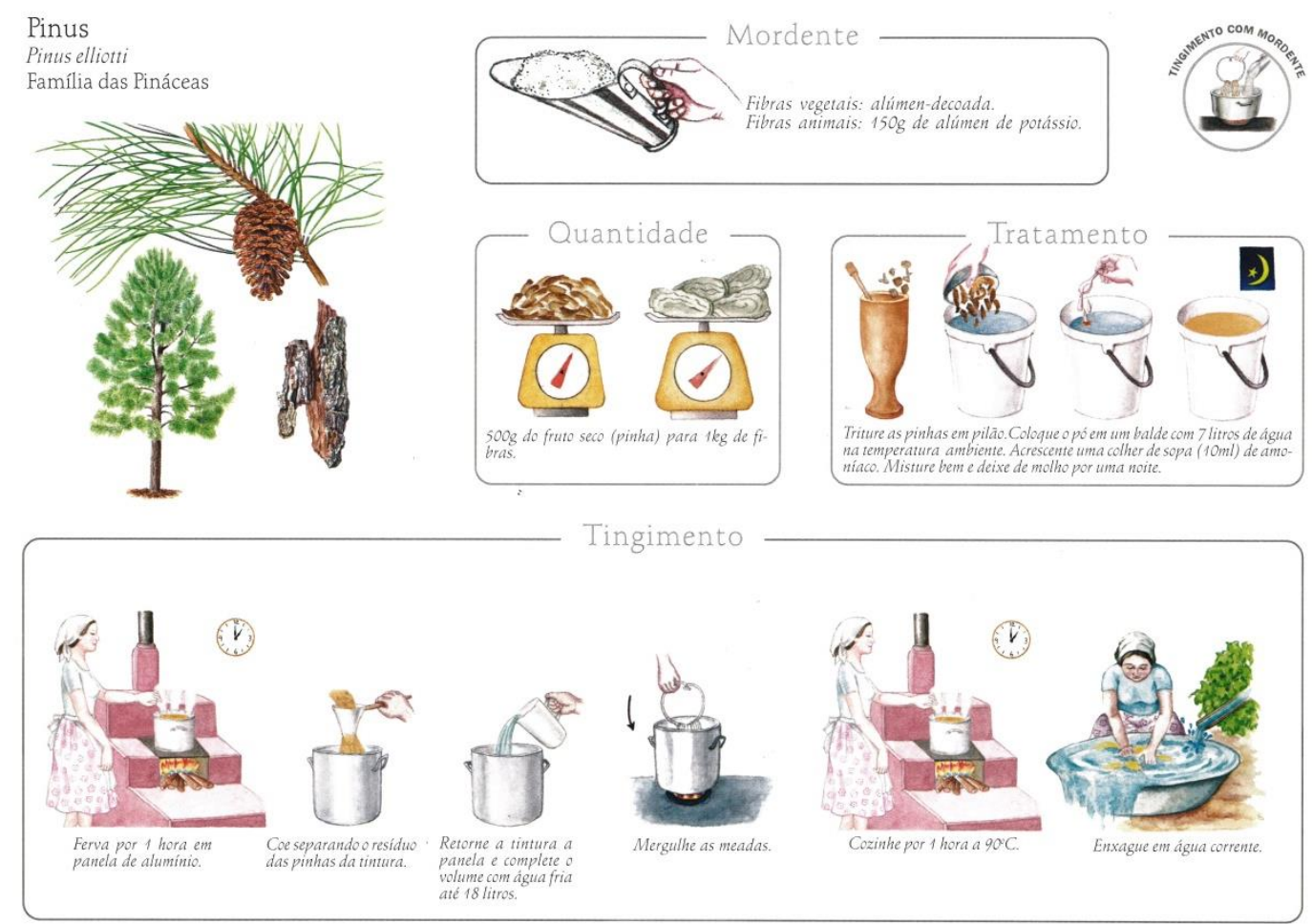

Fonte: Ferreira, 1998

\section{Extração do corante}

$10 \mathrm{~g}$ de pinha moída foram acrescentados a uma solução de $140 \mathrm{~mL}$ de água e $0,5 \mathrm{~mL}$ de amoníaco. Após permanecer de molho por um dia o extrato foi levado ao fogo por 1 hora e depois coado.

Figura 32 - Pinhas e extrato do pinus

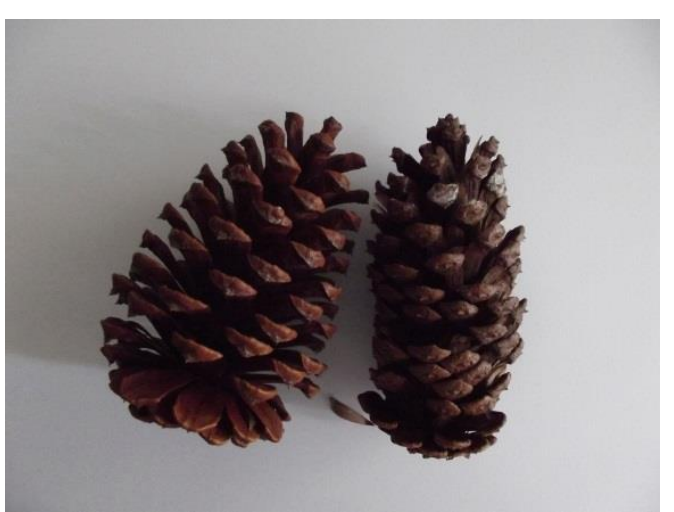

Pinhas

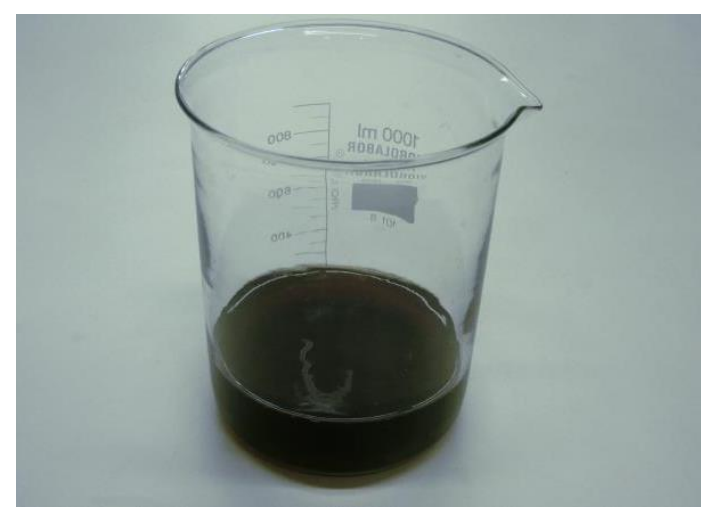

Extrato

Fonte: acervo do autor 


\section{Aplicação do mordente}

O tingimento com pinus e os demais vegetais que experimentamos aqui (excetuando o barbatimão) exigem um pré-tratamento das fibras para que recebam uma coloração homogênea e com boa fixação. Antes de leva-las ao tingimento, então, as fibras e o tecidotestemunha foram submetidos a um banho de $15 \mathrm{~g}$ de alúmen de potássio (mordente) dissolvidos em $1,8 \mathrm{~L}$ de água, por 30 minutos à $(90 \pm 5)^{\circ} \mathrm{C}$.

\section{Tingimento}

Ao extrato coado foram acrescentados mais $360 \mathrm{~mL}$ de água. As fibras de paina e o tecido-testemunha, depois de retirados do banho com o mordente, ficaram imersos no banho por $1 \mathrm{~h}$ a $(90 \pm 5){ }^{\circ} \mathrm{C}$. Após tingimento foi feito enxágue em água à temperatura ambiente.

Foi obtida uma cor bege rosada, similar ao do barbatimão. Na Figura 33 é possível verificar o resultado do tingimento com o pinus.

Figura 33 - Tingimento das fibras de paina com pinus

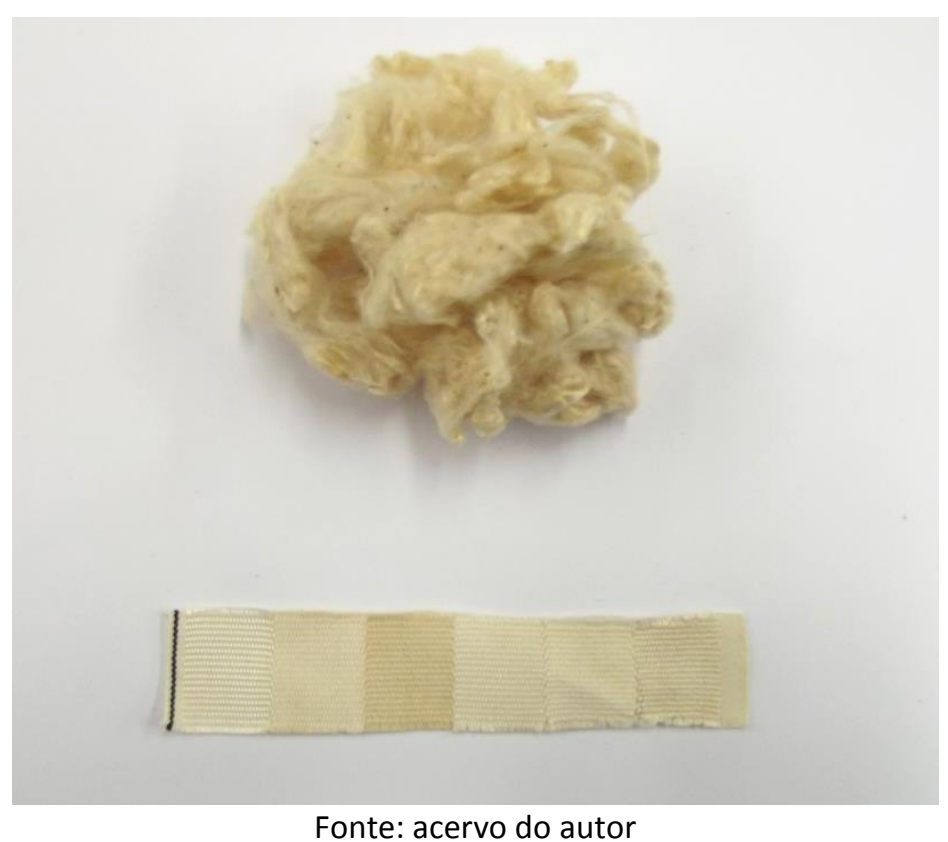

\subsubsection{Picão}

Planta herbácea de ocorrência em todo o Brasil, comum em pastos abandonados e áreas cultivadas (FERREIRA, 1998). Segundo Ferreira (1998) dos frutos do picão se extrai 
corante de cor cáqui, porém na receita é utilizada toda a planta. O picão utilizado nesse experimento (Figura 35) também foi coletado em uma chácara em Itapetininga. A Figura 34 a seguir apresenta a receita usada como referência para o tingimento.

Figura 34 - Receita de tingimento com o picão

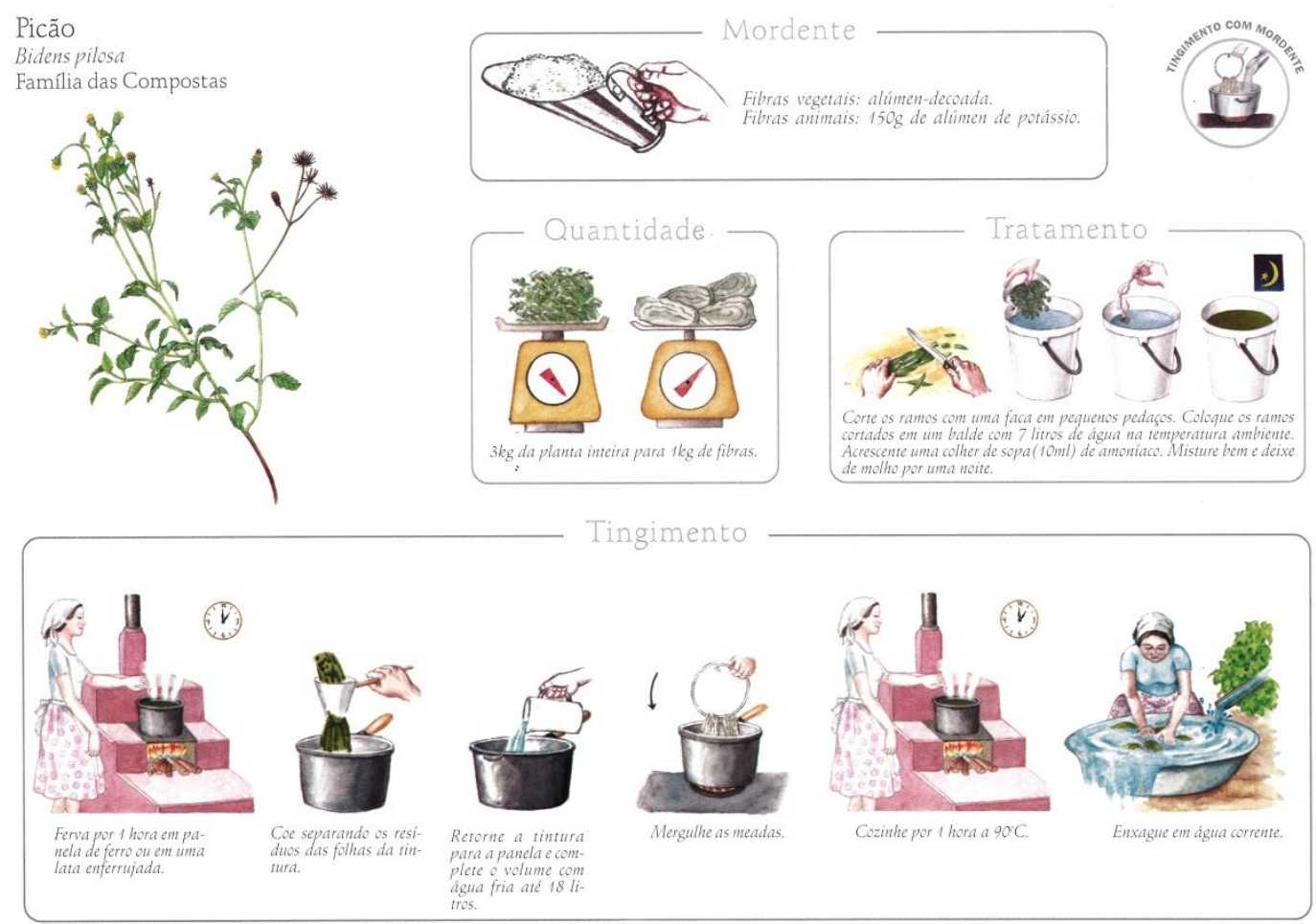

Fonte: Ferreira, 1998

\section{Extração do corante}

$30 \mathrm{~g}$ da planta foram acrescentados a uma solução de $70 \mathrm{~mL}$ de água e $0,1 \mathrm{~mL}$ de amoníaco. Após permanecer de molho por um dia o extrato foi levado ao fogo por 1 hora e depois coado.

Figura 35 - Picão e extrato do picão

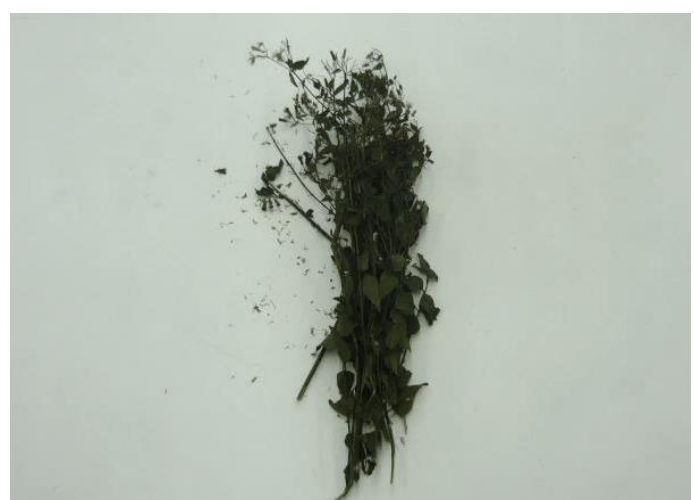

Galhos do picão

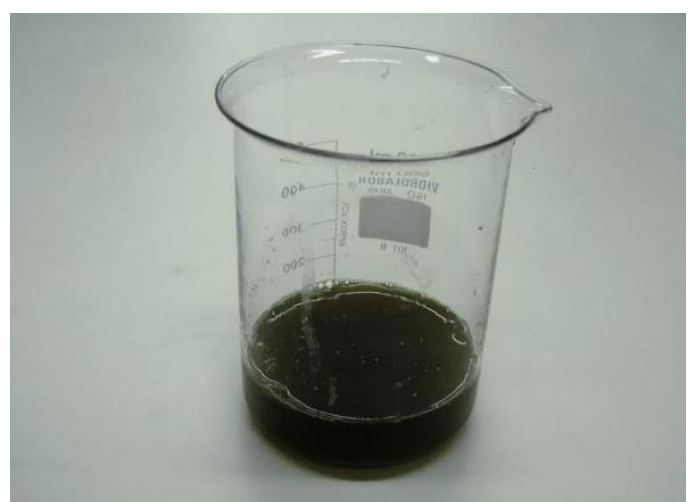

Extrato

Fonte: acervo do autor 
Aplicação do mordente

Foi utilizado o mesmo banho realizado para o pinus.

\section{Tingimento}

Ao extrato coado foram acrescentados mais $180 \mathrm{~mL}$ de água. As fibras de paina e o tecido-testemunha, depois de retirados do banho com o mordente, ficaram imersos no banho por $1 \mathrm{~h}$ a $(90 \pm 5){ }^{\circ} \mathrm{C}$. Após tingimento foi feito enxágue em água à temperatura ambiente. Embora o esperado fosse tingir a fibra de cinza ou caqui, foi obtida uma cor amarela ocre, porém, sabemos que fatores como a qualidade da água e tipo de recipiente influenciam no resultado da cor. Na Figura 36 é possível verificar o resultado do tingimento com o picão.

Figura 36 - Tingimento das fibras de paina com picão

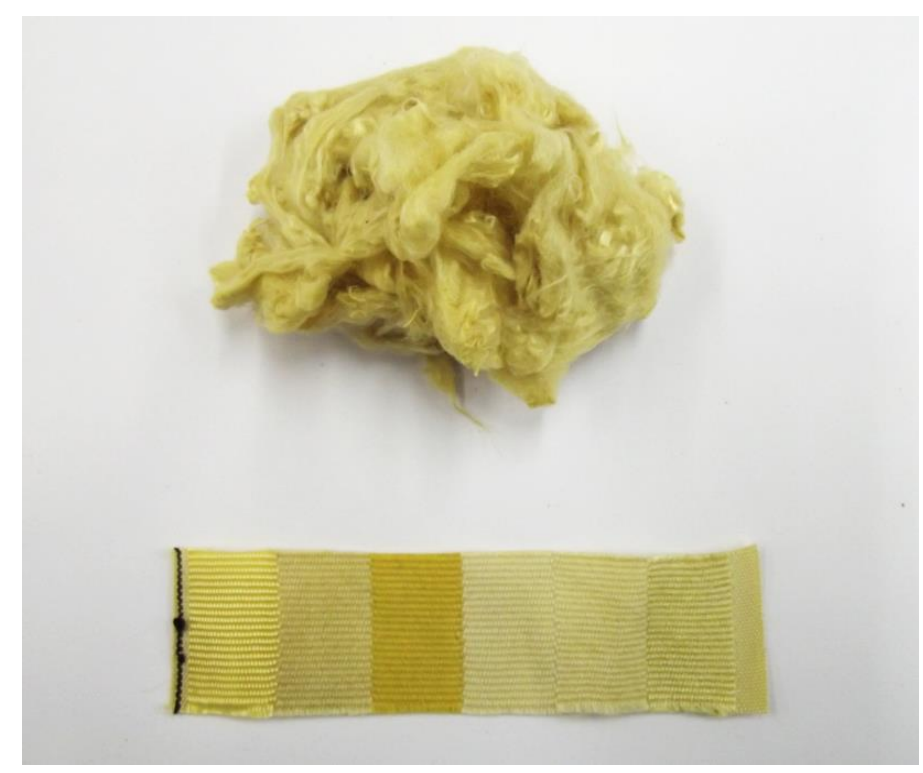

Fonte: acervo do autor

\subsubsection{Erva-mate}

Espécie arbórea, se desenvolve nas regiões temperadas do Brasil, como Santa Catarina, Rio Grande do Sul e Mato Grosso. Das folhas dessa espécie é produzido o chá mate e o chimarrão. O corante extraído também das folhas é amarelo-esverdeado e dependendo do recipiente e mordente utilizado a coloração pode variar do verde musgo ao cinza chumbo (FERREIRA, 1998). A Figura 37 a seguir apresenta a receita usada como referência para o tingimento. 
Figura 37 - Receita de tingimento com a erva-mate

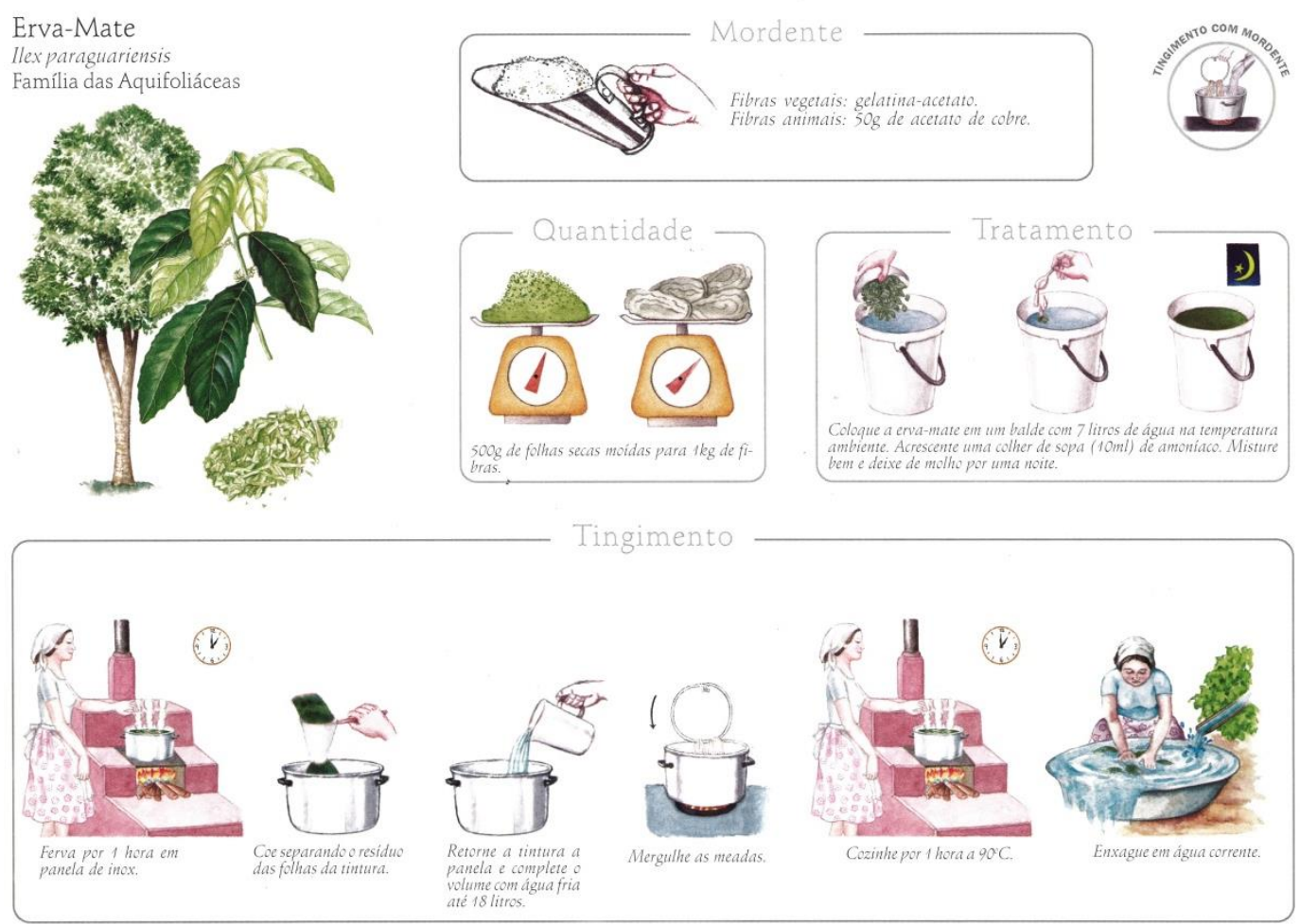

Fonte: Ferreira, 1998

\section{Extração do corante}

$5 \mathrm{~g}$ da planta foram acrescentados a uma solução de $70 \mathrm{~mL}$ de água e $0,1 \mathrm{~mL}$ de amoníaco. Após permanecer de molho por um dia o extrato foi levado ao fogo por 1 hora e depois coado.

Figura 38 - Folhas secas e extrato da erva-mate

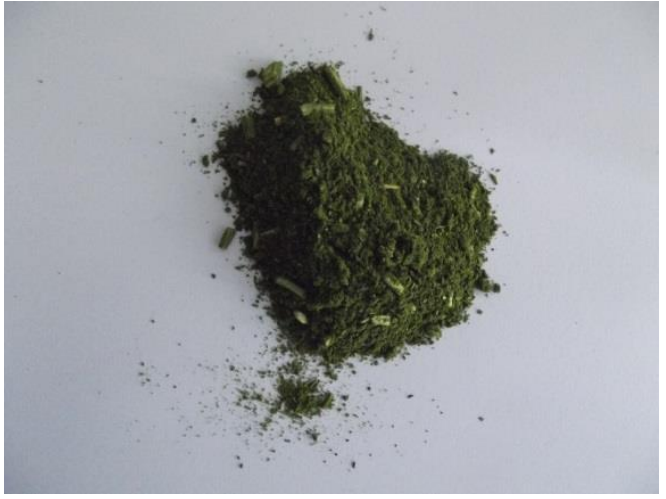

Folhas secas de erva-mate

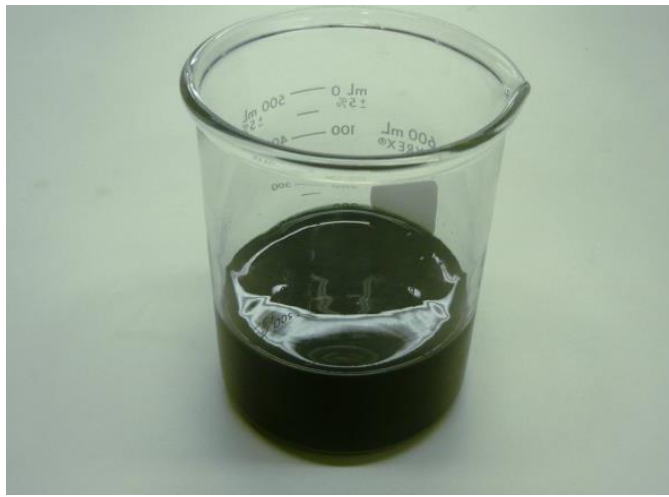

Extrato

Fonte: acervo do autor 


\section{Aplicação do mordente}

Foi utilizado o mesmo banho realizado para o pinus.

\section{Tingimento}

Ao extrato coado foram acrescentados mais $180 \mathrm{~mL}$ de água. As fibras de paina e o tecido-testemunha, depois de retirados do banho com o mordente, ficaram imersos no banho por $1 \mathrm{~h}$ a $(90 \pm 5)^{\circ} \mathrm{C}$. Após tingimento foi feito enxágue em água à temperatura ambiente.

Foi obtida a cor verde. Na Figura 39 é possível verificar o resultado do tingimento com a erva-mate.

Figura 39 - Tingimento das fibras de paina com erva-mate

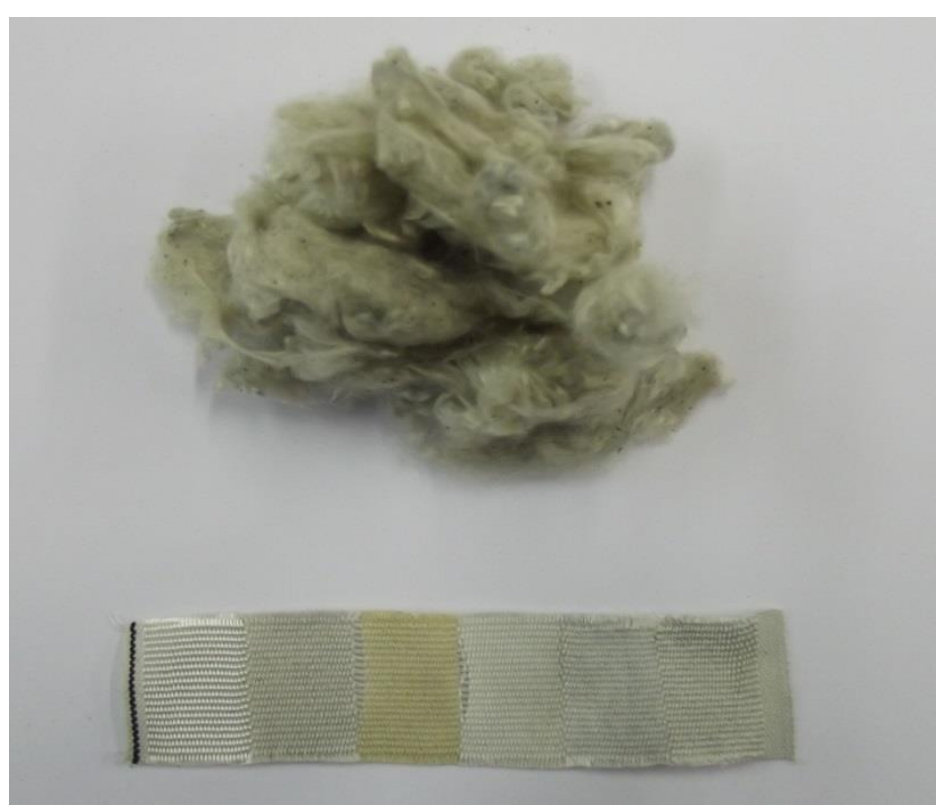

Fonte: acervo do autor

\subsubsection{Espinafre}

Espécie herbácea, nativa da costa sul e sudeste brasileira e cultivada em todo o Brasil, o espinafre tem folhas ricas em clorofila e ferro (FERREIRA, 1998). É a clorofila que tem a propriedade tintorial, porém, segundo Ferreira (1998) só se torna corante estável por meio de uma alteração da sua composição química. Que é feita por meio do uso de mordentes e recipientes específicos. 
Figura 40 - Receita de tingimento com o espinafre

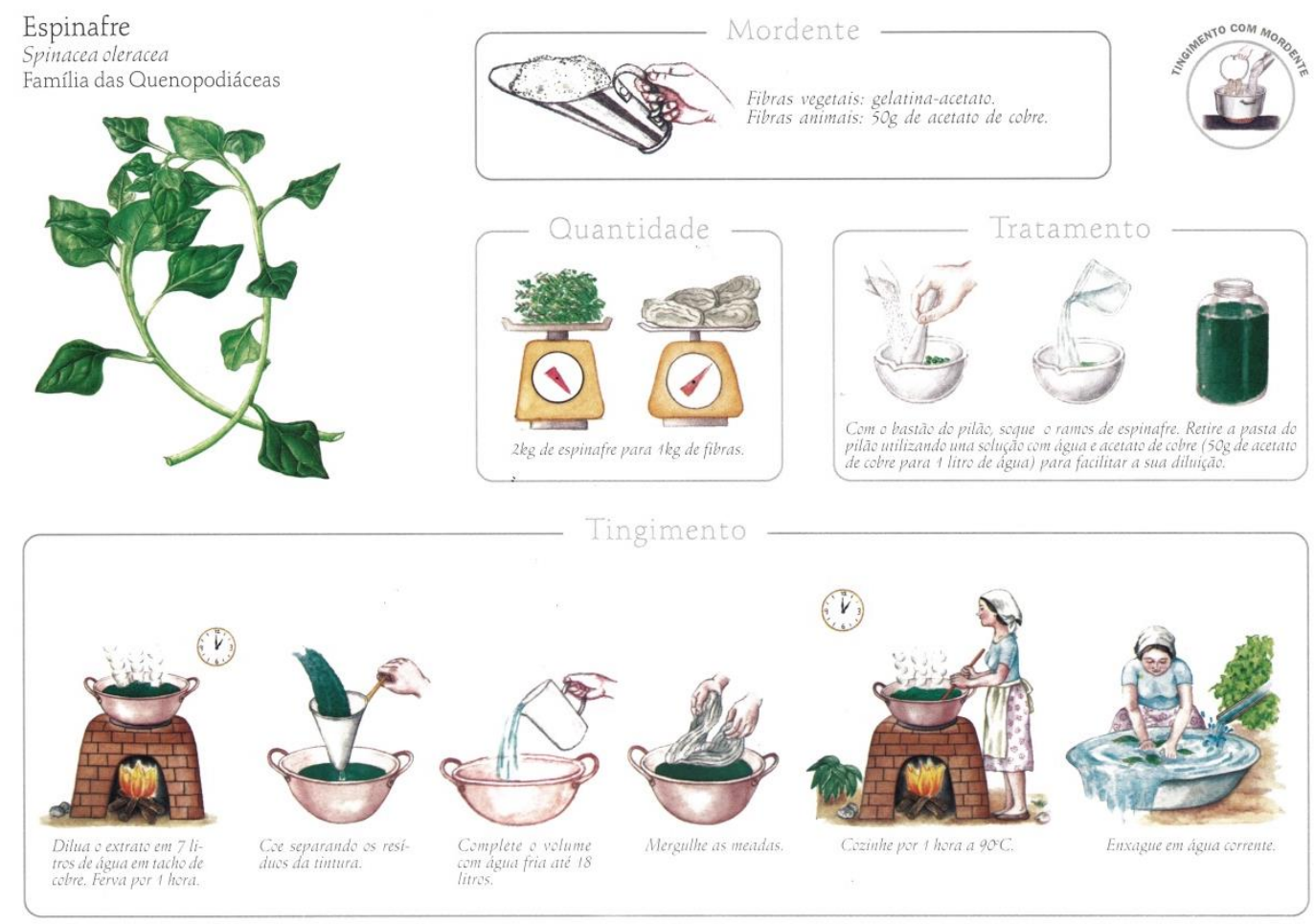

Fonte: Ferreira, 1998

\section{Extração do corante}

Conforme receita descrita na Figura 40 para tornar o corante estável Ferreira (1998) recomenda o uso de acetato de cobre no procedimento de extração do corante. Porém, como mencionamos anteriormente, por uma restrição na obtenção de alguns produtos químicos, o mordente que utilizamos em todos os experimentos foi o alúmen de potássio (pedra-ume).

Foi feito então um primeiro experimento na extração do corante substituindo o acetato de cobre pelo alúmen de potássio. Porém, o resultado não foi satisfatório, pois a fibra e o tecido-testemunha não tingiram.

No segundo experimento tentamos realizar o processo de extração com amoníaco, como indicado nas demais receitas: $20 \mathrm{~g}$ da planta fresca, macerada em pilão, foram acrescentados a uma solução de $70 \mathrm{~mL}$ de água e $0,1 \mathrm{~mL}$ de amoníaco. Após permanecer de molho por um dia o extrato foi levado ao fogo por 1 hora e depois coado. 
Figura 41 - Planta e extrato do espinafre

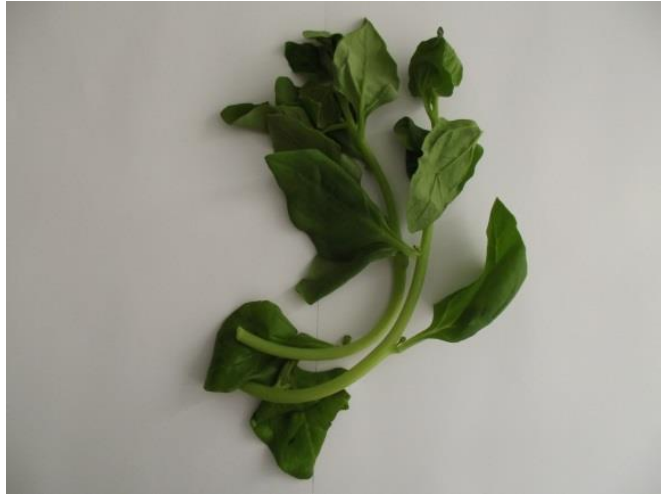

Ramos de espinafre

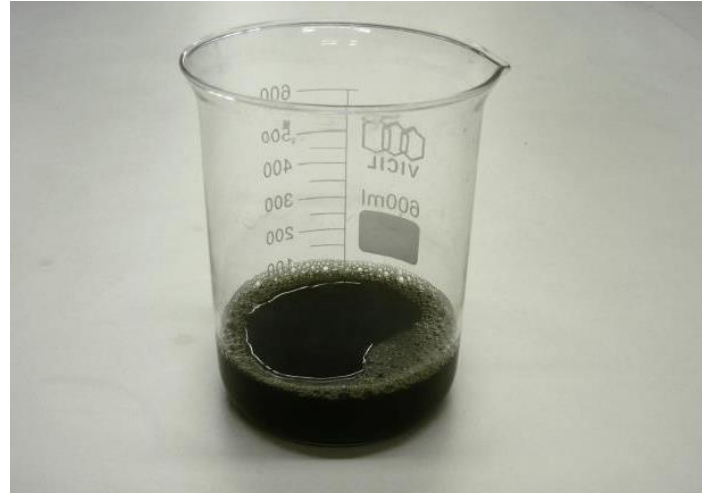

Extrato

Fonte: acervo do autor

Aplicação do mordente

Foi utilizado o mesmo banho realizado para o pinus.

\section{Tingimento}

Ao extrato coado foram acrescentados mais $180 \mathrm{~mL}$ de água. As fibras de paina e o tecido-testemunha, depois de retirados do banho com o mordente, ficaram imersos no banho por $1 \mathrm{~h}$ a $(90 \pm 5)^{\circ} \mathrm{C}$. Após tingimento foi feito enxágue em água à temperatura ambiente.

Do segundo experimento, feito com amoníaco, foi obtida uma cor verde-amarelada. Na Figura 42 é possível verificar o resultado do tingimento com o espinafre.

Figura 42 - Tingimento das fibras de paina com espinafre

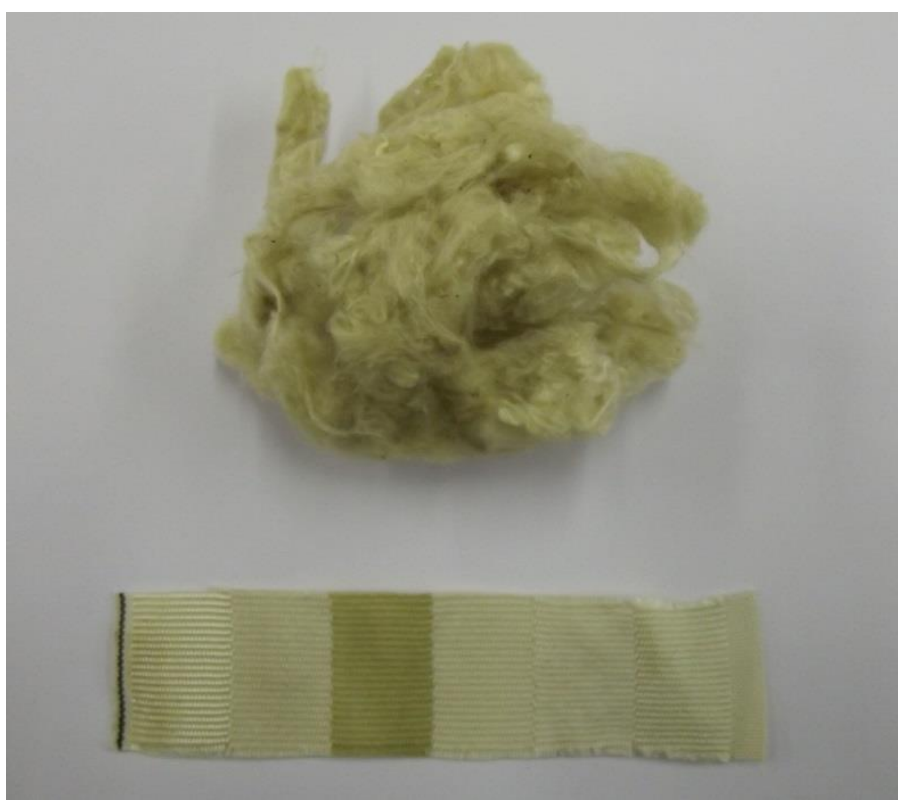

Fonte: acervo do autor 


\subsubsection{Mangueira}

Espécie arbórea, nativa do sul e sudeste asiático e cultivada em regiões tropicais, a mangueira também fornece material corante. Das suas cascas é possível extrair um corante que varia de amarelo a verde. Nesse experimento foram utilizadas as cascas do troco extraídas em uma chácara em Itapetininga (Figura 44). A referência da receita foi retirada de um trabalho também realizado por Ferreira (2004) com tingimentos naturais em fibras de taquara junto a uma comunidade Guarani da Aldeia Boa Vista (Ubatuba - SP). A Figura 43 a seguir apresenta a descrição da receita usada como para o tingimento.

Figura 43 - Receita de tingimento com a mangueira

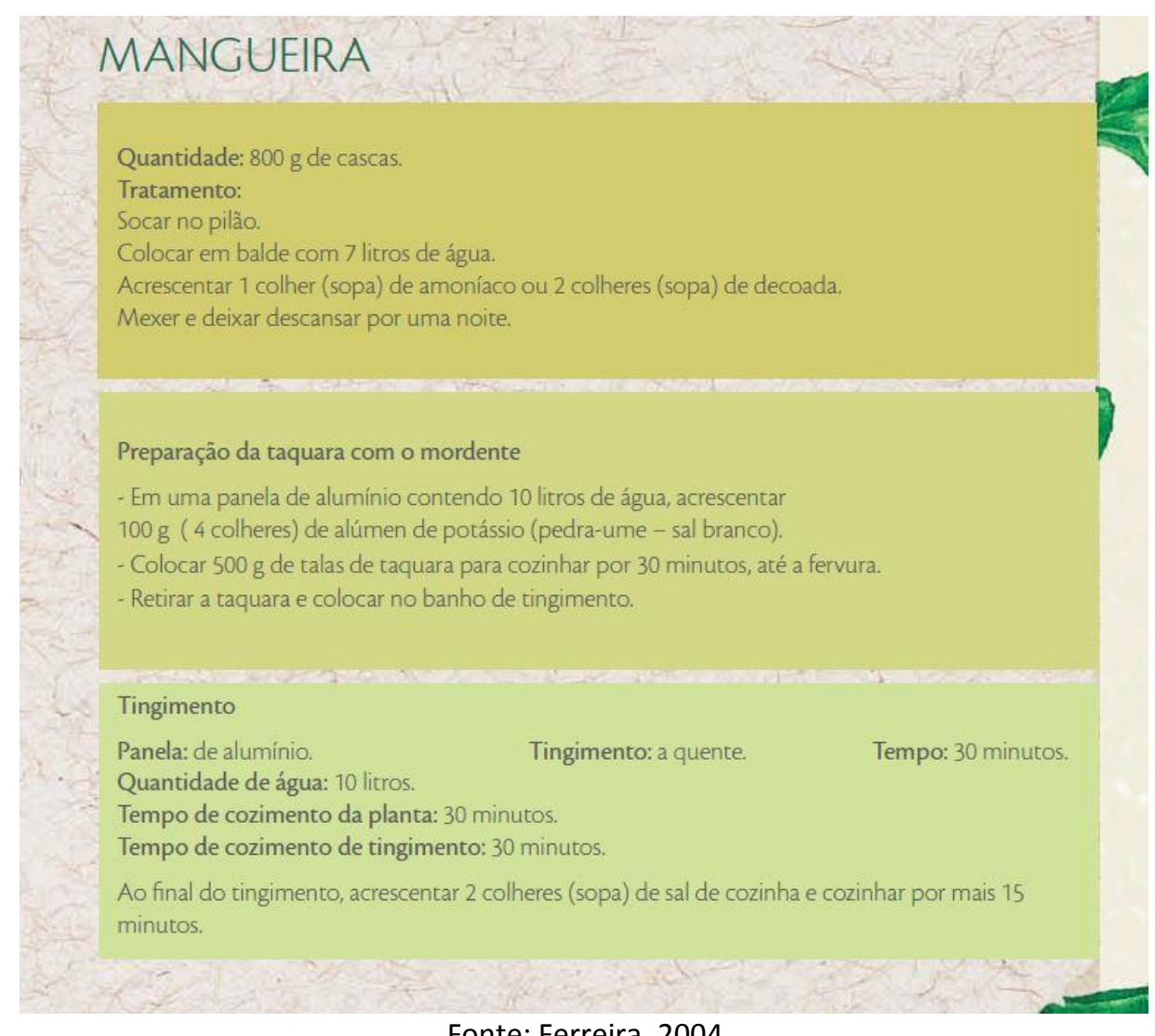

Fonte: Ferreira, 2004

\section{Extração do corante}

$8 \mathrm{~g}$ de cascas moídas foram acrescentados a uma solução de $70 \mathrm{~mL}$ de água e $0,1 \mathrm{~mL}$ de amoníaco. Após permanecer de molho por um dia o extrato foi levado ao fogo por 1 hora e depois coado. 
Figura 44 - Cascas e extrato da mangueira

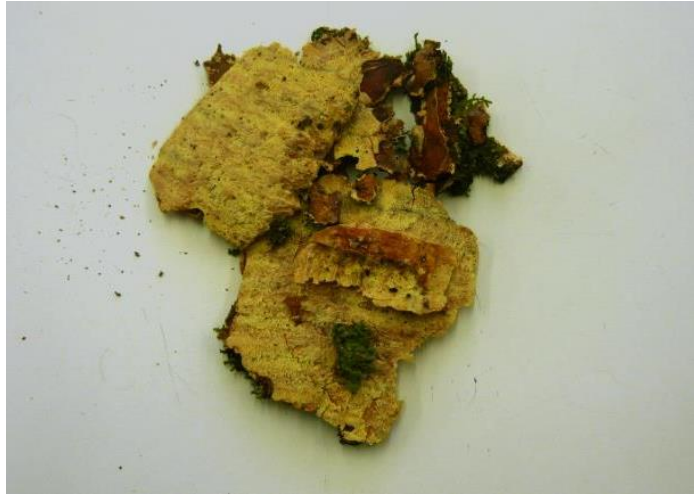

Cascas da mangueira

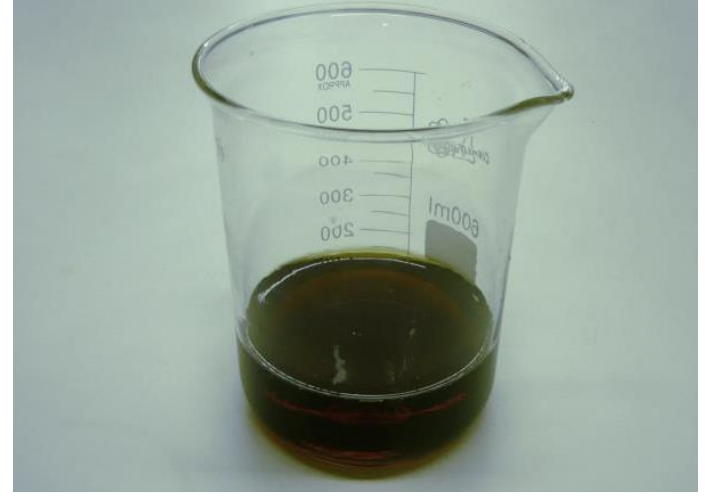

Extrato

Fonte: acervo do autor

\section{Aplicação do mordente}

Foi utilizado o mesmo banho realizado para o pinus.

\section{Tingimento}

Ao extrato coado foram acrescentados mais $100 \mathrm{~mL}$ de água. As fibras de paina e o tecido-testemunha, depois de retirados do banho com o mordente, ficaram imersos no banho por $1 \mathrm{~h}$ a $(90 \pm 5){ }^{\circ} \mathrm{C}$. Após tingimento foi feito enxágue em água à temperatura ambiente.

Foi obtida a cor amarela muito viva. Na Figura 45 é possível verificar o resultado do tingimento com a mangueira.

Figura 45 - Tingimento das fibras de paina com cascas da mangueira

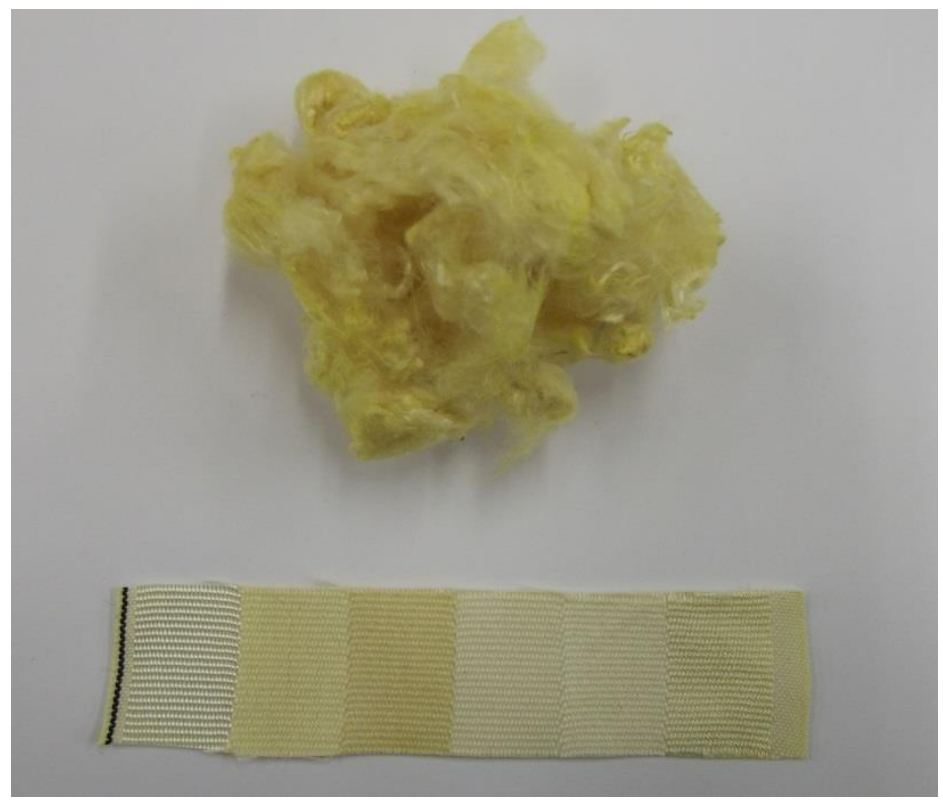

Fonte: acervo do autor 
Como é possível verificar nos tecidos-testemunhas que foram tintos junto às fibras de paina, em todos os experimentos as cores obtidas nas fibras de paina ficaram mais vivas do que no algodão (segunda faixa da direita para esquerda), fibra de mesma natureza que a paina: celulósica natural. Isso demonstra o potencial de tingimento da paina. Notamos nesses experimentos que a aplicação do banho de mordente antes do tingimento facilita o tingimento da paina, não apenas pelas propriedades do mordente propriamente dito, mas pelo fato da paina ser uma fibra muito leve e lisa, que custa a entumecer e tende a ficar na superfície do banho. Quando submetida ao banho com mordente e em seguida levada ao banho de tingimento, esta já se encontra úmida e imerge com mais facilidade.

A partir dos experimentos descritos acima, foi possível confirmar a possibilidade de tingir as fibras de paina com os corantes selecionados segundo a cartela de cor da coleção. Algumas tonalidades e cores específicas da cartela de cor poderão ser obtidas utilizando no tingimento alguns recipientes específicos que influenciam nas cores (como a panela de cobre para deixar as cores mais vivas e a de ferro para escurecê-las), misturando os corantes para obter cores novas, ou ainda repetindo os tingimentos para intensificar cores. 


\section{A coleção}

Este capítulo é dedicado à fase de criação da pesquisa. Depois da pesquisa teórica a cerca dos conceitos e tendências para a coleção e da pesquisa experimental para avaliar a viabilidade de emprego das fibras de paina no desenvolvimento de fios e sua tingibilidade, aqui apresentamos os resultados do processo criativo, fruto dos resultados da pesquisa teórica e experimental, somados à nossa percepção de mundo.

A metodologia do processo de criação utilizada para execução desta fase do trabalho foi baseada na maneira clássica e convencional de apresenta-la à indústria da moda, em especial pelos escritórios de estilo. Com base nas suas pesquisas, esses escritórios publicam cadernos de tendências, onde apresentam temas, conceitos, cartelas de cor para a criação (FRINGS, 2005; LEÃO, 2002 e VICENT-RICARD, 1989). Essa também é a forma com que a indústria têxtil se apropriou para oferecer seus produtos e inovações ao mercado, apresentando-os junto à ideias e sugestões de coleção, incluindo imagens, cartelas de cores, amostras de tecidos, esboço de looks, etc. (FRINGS, 2005). Esta é a metodologia de desenvolvimento de coleção mais difundida globalmente, porém, não é a única. Como mencionado em outros momentos do trabalho, o intuito de utiliza-la é aproximar nossa proposta a esta linguagem e demonstrar que é possível trabalhar interdisciplinarmente, de forma a facilitar a inserção de um produto novo no mercado.

\subsection{Tema}

A Natureza no concreto

$\mathrm{Na}$ paisagem predominantemente urbana das grandes cidades, o que num passado muito distante o concreto viria a ser uma intervenção do homem na natureza, hoje é ela que se manifesta como uma invasora.

As manifestações espontâneas da natureza no concreto, que vão além daquilo que é controlado e desejado pelo homem (como por exemplo, os jardins), são o tema dessa coleção.

Ao observamos essas intervenções espontâneas da natureza, desvendamos uma linguagem que vai ao encontro das tendências que apresentamos no capitulo anterior. $O$ concreto é o elemento que hoje divide dois ritmos, dois planos que coexistem: acima dele: o 
fluxo, o movimento, a velocidade e a superficialidade, viabilizados pelas tecnologias e o agito da vida urbana e abaixo dele: um ritmo denso, profundo e lento, representado pela terra, raízes e plantas. Este último, por muito tempo oculto e reprimido pela lógica urbana, emerge do solo e permeia a barreira rígida do concreto, aludindo à imposição, ou sobreposição, de uma "nova" lógica.

Essa natureza que "nasce" no concreto, representa a emergência dos movimentos lentos, do resgate à memória ancestral, à essência, daquilo que é "puro e inalterado" (TEXTILE VIEW MAGAZINE, 2012) e sua associação ao ritmo urbano. 


\subsection{Ambiência}

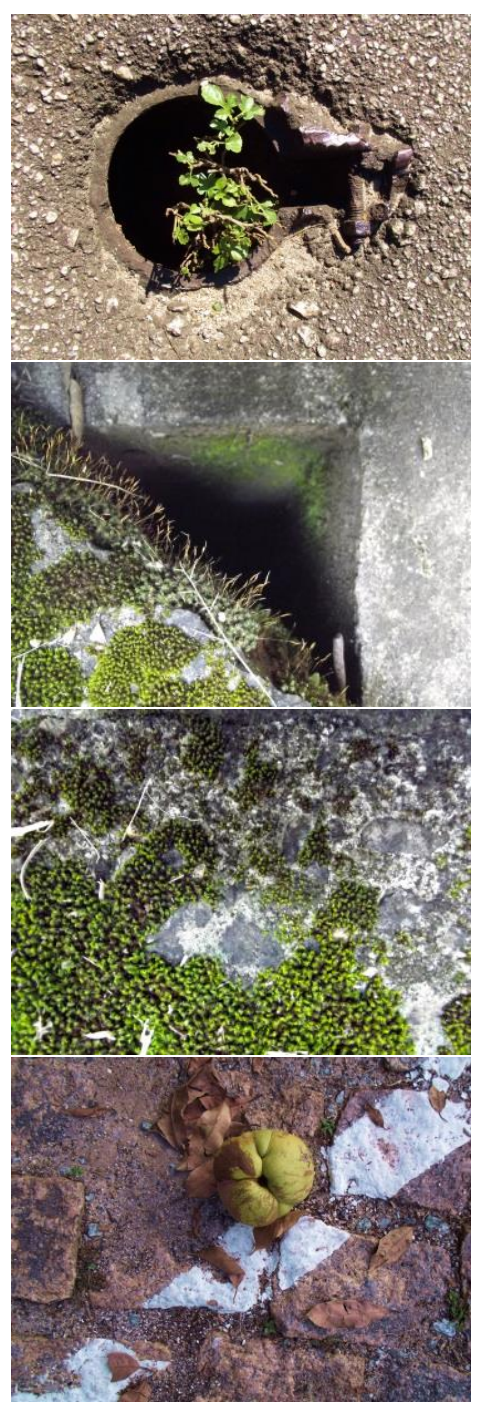

Figura 46 - Ambiência

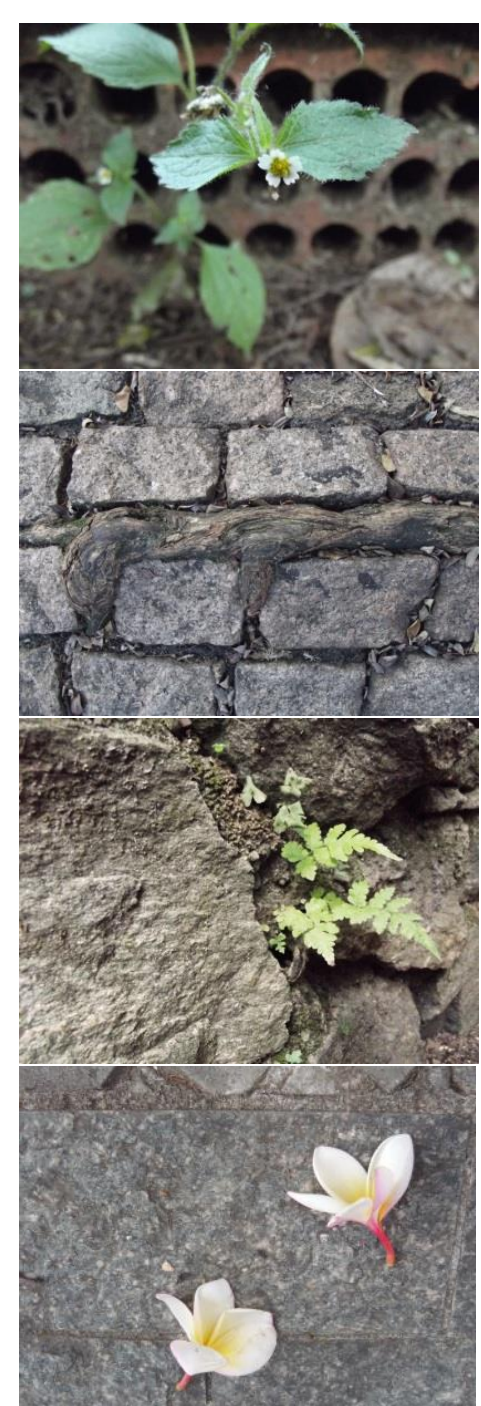

Fonte: acervo do autor
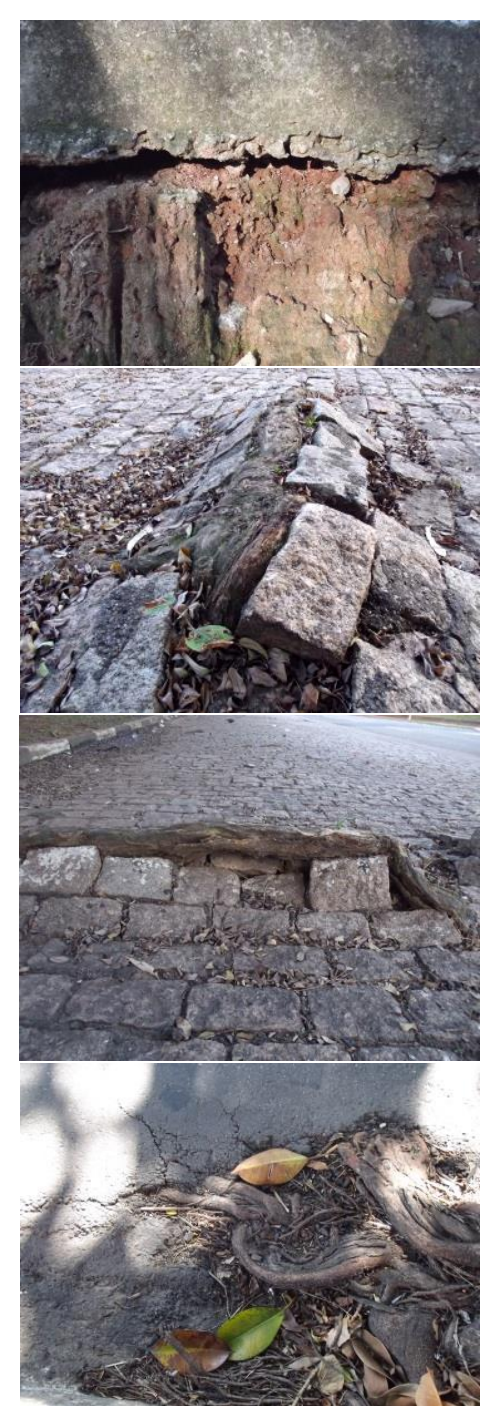
4.4 Cartela de cores
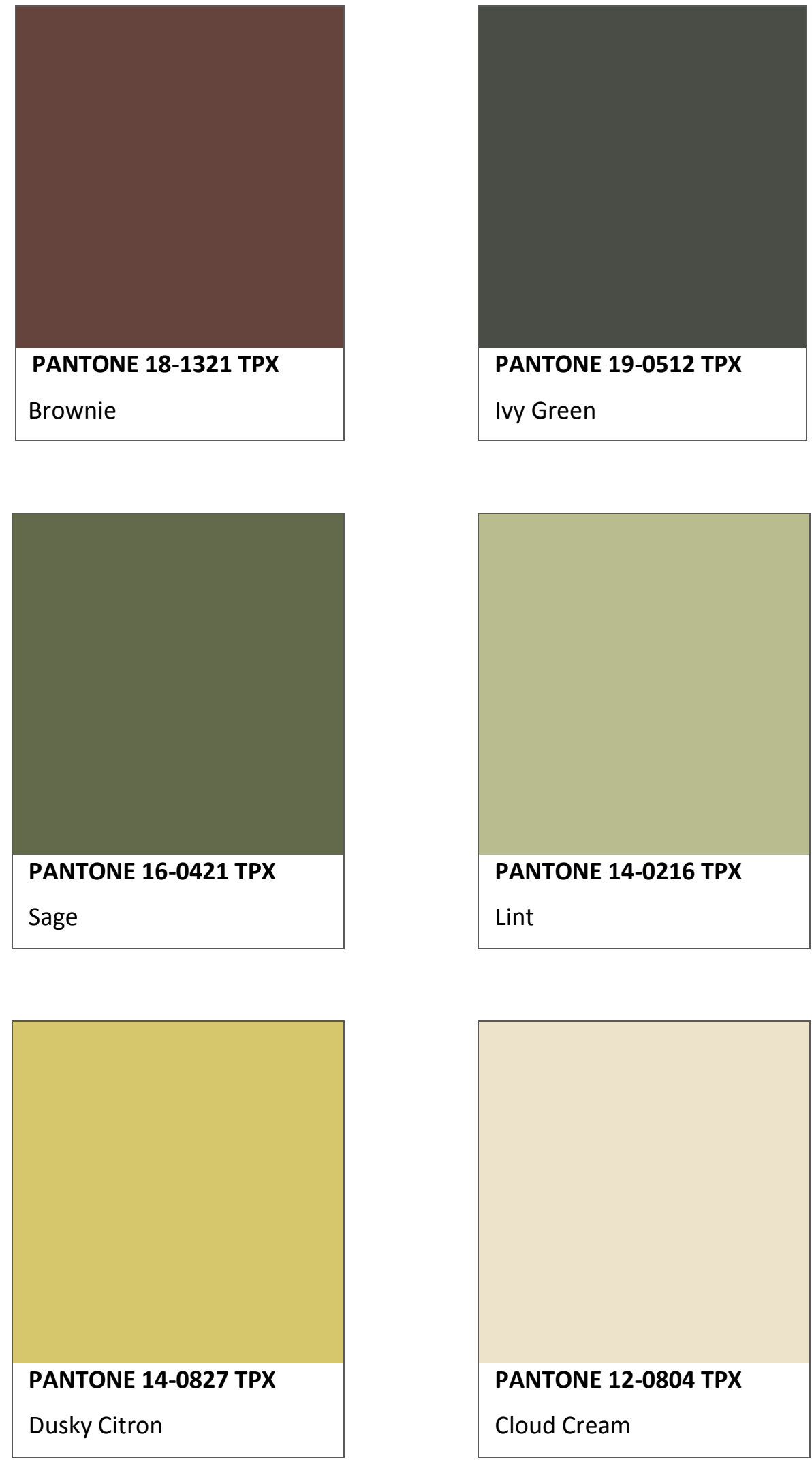


\subsection{Cartela de fios}

Figura 47 - Cartela de fios da coleção
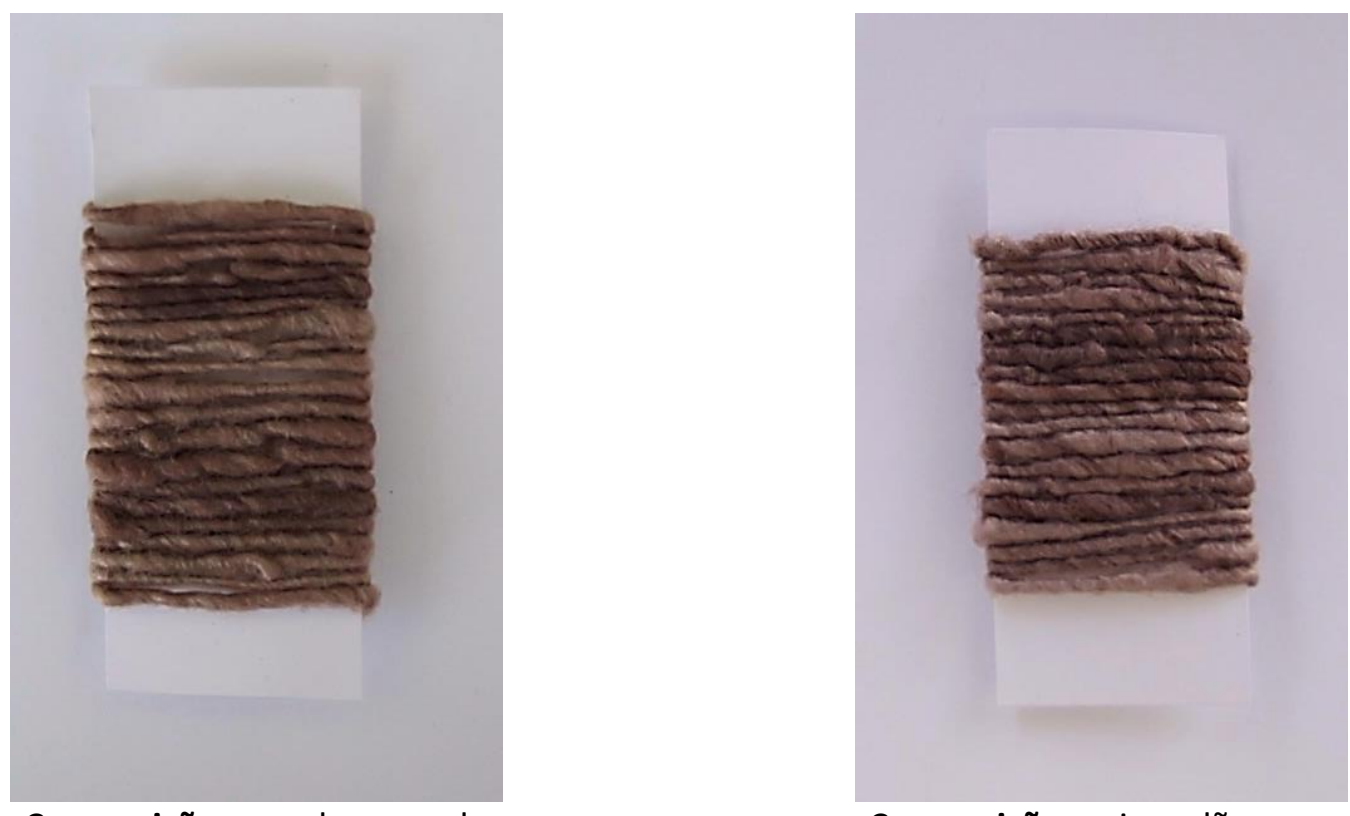

Composição: alma de algodão revestida de paina

Composição: paina e lã

Tingimento: mate (torrado) e barbatimão em panela de

Tingimento: mate (torrado) e

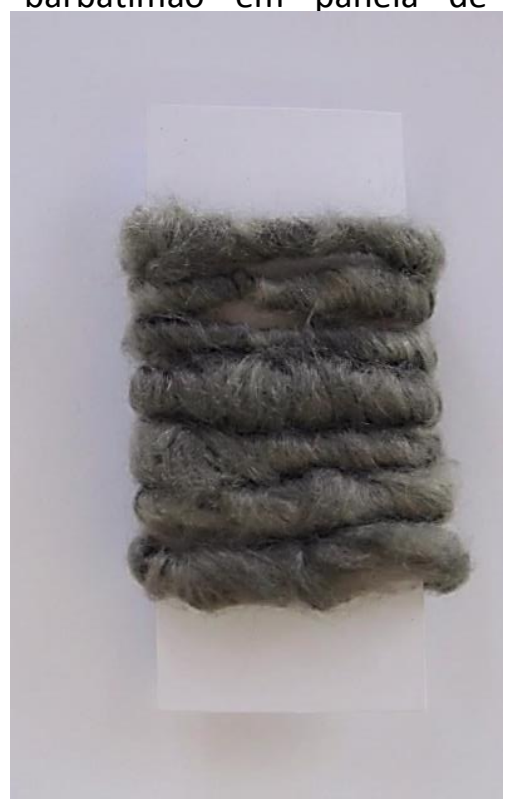

Composição: paina e algodão

Tingimento: erva-mate em panela de ferro 
Figura 46 - Cartela de fios da coleção (continuação)

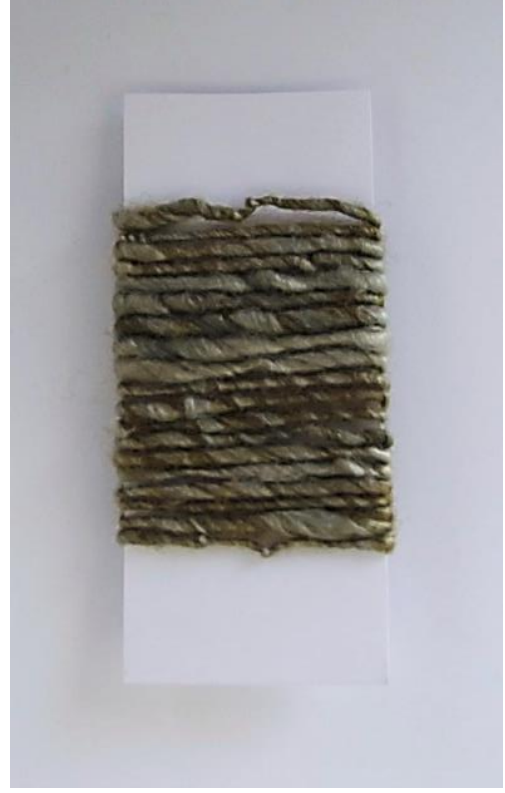

Composição: paina e lã

Tingimento: erva-mate em panela de cobre

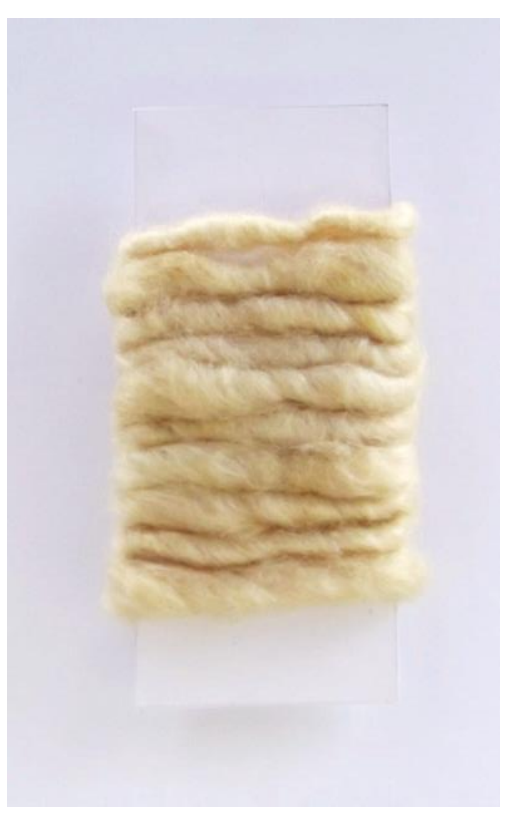

Composição: paina e algodão

Tingimento: casca de manga em panela de alumínio

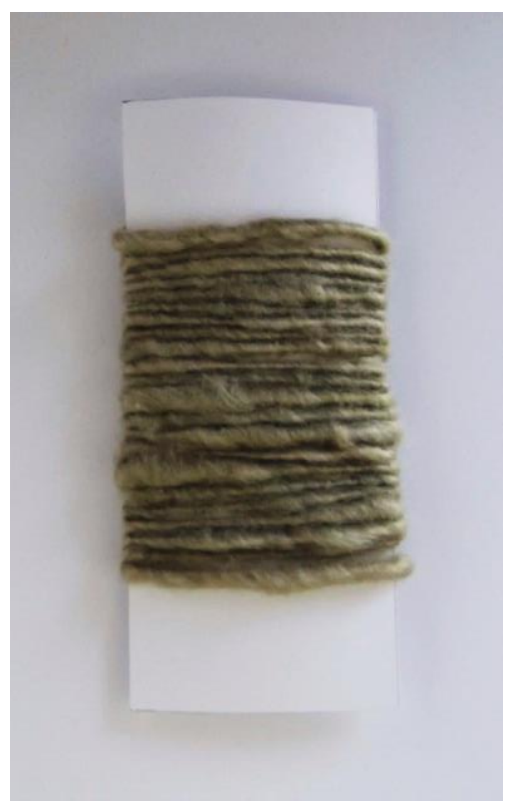

Composição: paina e algodão

Tingimento: erva-mate em panela de cobre

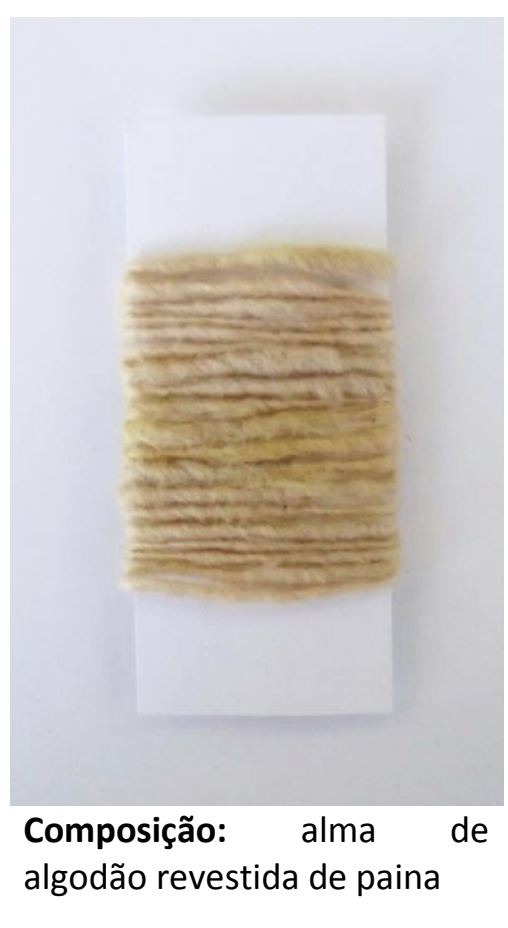

Tingimento: espinafre em panela de alumínio

Fonte: acervo do autor 
Figura 48 - Coleção de fios de paina

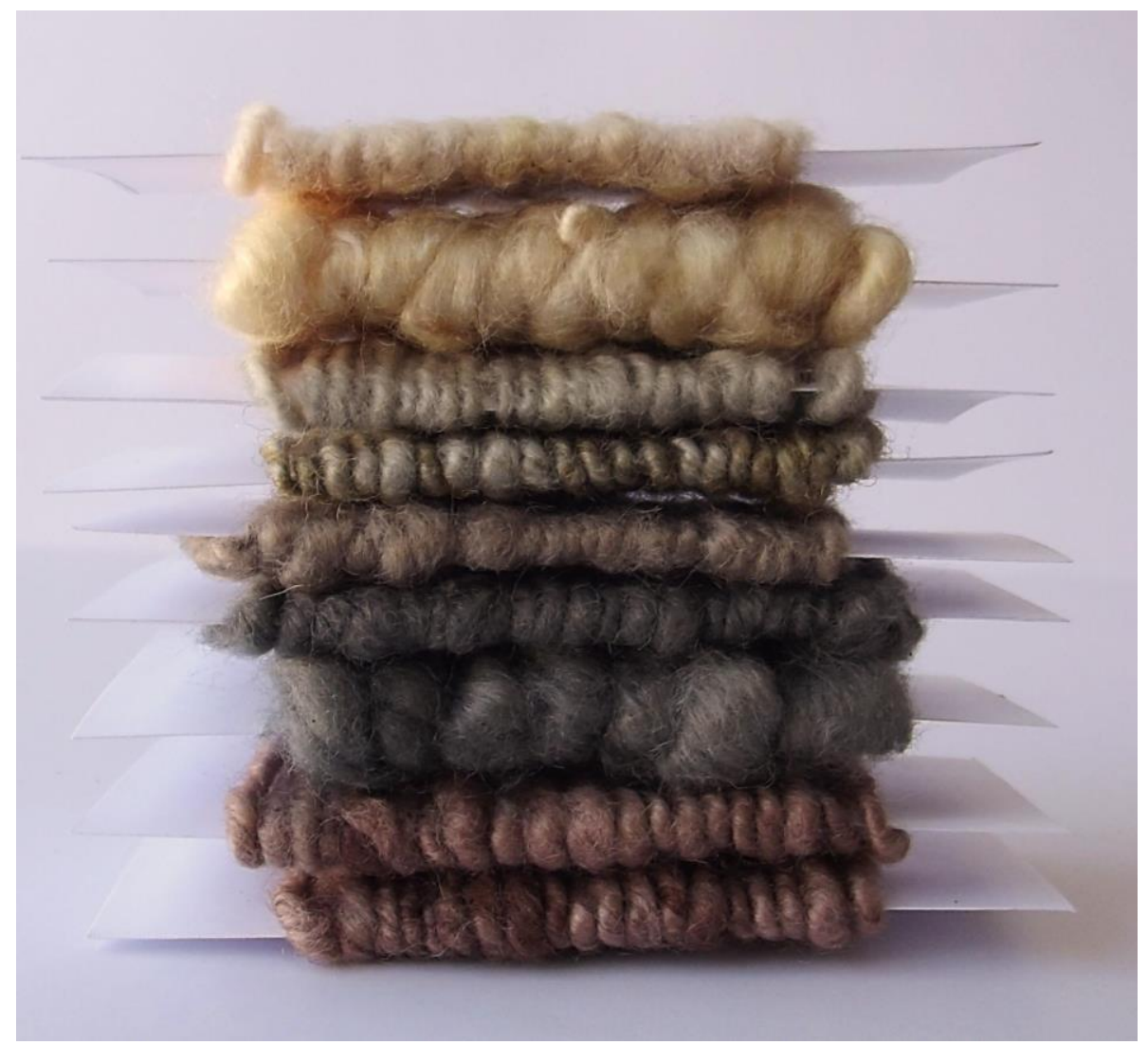

Fonte: acervo do autor 


\section{Considerações finais}

A pesquisa e desenvolvimento de materiais a partir de fibras têxteis vegetais nativas do Brasil são de extrema importância não apenas no que se refere a geração de novos tipos de materiais das mais variadas aplicações (da moda aos têxteis técnicos), com qualidades e desempenho específicos, como também à possibilidade de propor materiais de reduzido impacto ambiental, obviamente associados a formas de cultivo e processos também de reduzido impacto ambiental. Nesse sentido, a valorização das técnicas e do conhecimento popular tradicional associada à pesquisa e inovação, proporciona um dos caminhos para o desenvolvimento e emprego de processos e lógicas de produção mais éticas e sustentáveis nas áreas que compreendem a moda e sua produção têxtil.

É válido considerar, porém, que a avaliação do desempenho dos aspectos ambientais de produtos exige a aplicação de ferramentas e metodologias, por exemplo a análise de ciclo de vida (ACV), capazes de mensurar os impactos associados ao seu desenvolvimento e produção. Assim, a avaliação do desempenho ambiental pode ser um dos desdobramentos futuros deste trabalho.

Da pesquisa acerca do etnodesign e etnotânica têxtil no Brasil, foi possível identificar um vasto conhecimento popular a cerca das técnicas têxteis, somados a um conhecimento amplo de uma diversidade de matérias primas vegetais destinadas tanto à extração de fibras têxteis como para o preparo de corantes. Isso indica o enorme potencial desses conhecimentos e processos serem incorporados no processo criativo têxtil, associando-os a uma abordagem de moda mais lenta, mais transparente (CLARK, 2008) e de fato comprometida com as implicações sociais, culturais e ambientais, abordagem esta que vai ao encontro das lógicas de produção artesanal, ainda desenvolvida dentro de comunidades rurais, como a comunidade estudada por Duarte (2009) e as vinculadas a programas desenvolvidos por Organizações não governamentais. Na perspectiva de que futuramente este, e outros trabalhos similares, possam ser levados à prática em comunidades, identificamos, sobretudo, como esse conhecimento é viável por meio de uma troca e uma nova abordagem. Assim, motivado por princípios de troca e empatia, acreditamos que não só é possível incorporar inovações que possibilitem a melhoria da qualidade de vida dessas comunidades e manutenção da sua cultura, como também é possível nós - sociedade 
"dominante" - assimilarmos, no mínimo, distintas lógicas de vida, trabalho e relação com a natureza, também visando a melhoria da qualidade de vida.

As tendências de moda pesquisadas demonstraram que uma parcela da sociedade vive na atualidade uma intensa e acelerada redefinição de conceitos, valores e estilo de vida que contrariam a configuração do mercado de moda e a lógica de consumo predominante inerente a este, e se projetam gradativamente em transformações nos comportamentos de consumo e consequentemente no mercado e economia. Ao contrário do que imaginávamos, que as tendências levantadas no bureaux de estilo, ao orientarem a coleção, seriam determinantes apenas no que se refere aos elementos estéticos-formais, vimos que há uma forte coesão entre os conceitos que essas tendências prospectam e os valores que delinearam este trabalho. Assim, elas apenas reafirmam a valia da presente pesquisa para 0 mercado de moda e a propensão deste à aceitação de produtos como o que propusemos aqui.

Ainda no que se refere às tendências, pudemos verificar que a fusão entre a tradição e as tecnologias atuais, conforme afirmou Vicent-Ricard (1989), é um dos principais aspectos que caracterizam a sociedade têxtil contemporânea, reforçando a importância de unir a pesquisa técnico-científica ao conhecimento popular tradicional para a criação de novos produtos e processos têxteis.

Da pesquisa técnico-experimental confirmamos a viabilidade de fiação da paina com misturas de algodão e lã, cada qual com características específicas. Porém, a fiação de um fio $100 \%$ paina, considerando critérios como uma fiação contínua, regularidade do fio e resistência, não foi possível a partir das técnicas de fiação utilizadas. Sugere-se assim, para trabalhos futuros, um estudo mais profundo, visando experimentações com técnicas distintas, ou mesmo o aperfeiçoamento ou desenvolvimento de técnicas e ferramentas mais especificas para a fiação da paina pura. Quanto aos experimentos de tingimento, foi verificado que a paina não só permite o seu tingimento, como também apresentou um potencial, quanto à intensidade das cores, extremamente superior ao algodão, fibra de mesma natureza que a paina: celulósica natural. É importante ressaltar que, embora tenhamos chegado num protótipo de produto, antes dos fios de paina se tornarem um produto de fato, é essencial que sejam avaliados tecnicamente quanto suas propriedades físico-químicas. A realização de ensaios de caracterização e avaliação do desempenho, não 
só podem indicar melhorias no desenvolvimento dos fios, como também apontar o potencial dessas fibras na aplicação de diversos materiais têxteis que exijam um desempenho específico (por exemplo têxteis técnicos) e, também, suas limitações a outras aplicações. Num primeiro momento, com o intuito de avaliar a qualidade dos fios obtidos por meio das técnicas que utilizamos neste trabalho consideramos importante a avaliação de propriedades como a resistência à tração, a fim de verificar a resistência à ruptura dos fios de diferentes misturas, e solidez da cor sob várias ações, como fricção, lavagem doméstica e luz, a fim de verificar a fixação dos corantes na fibra. Porém, como dito, há ainda uma infinidade de ensaios que podem ser realizados num produto acabado para determinar propriedades mais específicas segundo sua aplicação final. A melhoria da qualidade dos fios que desenvolvemos aqui também poderá ser alcançada por meio de uma mão-de-obra mais especializada e/ou ainda por meio do aprimoramento das ferramentas para fiação manual.

A aplicação dos fios desenvolvidos na elaboração de maquetes de tecido, como proposto inicialmente na pesquisa, também é outra etapa bastante pertinente no processo de transformação de um produto em desenvolvimento em um produto de fato, já que elaboração desses protótipos de tecido pode ser um interessante método para experimentação de novos materiais e técnicas, dos quais se desconhece o efetivo potencial têxtil e suas características táteis e para execução de projetos criativos de design têxtil com ênfase em moda.

Por fim, a partir deste trabalho foi possível ratificar a importância e potencial de aliar a pesquisa científica à criação de moda tanto para o desenvolvimento de um novo material, fios produzidos a partir das fibras de paina, como na proposição de formas de produção e consumo de moda mais lentos e, portanto, ambientalmente e socialmente mais éticos. $E$ sendo a moda um eficiente propagador de valores, o desenvolvimento de produtos a partir desta lógica associados à pesquisa de tendências de moda e design é uma interessante estratégia para inserir uma distinta forma de produção e consumo de moda dentro da própria lógica de moda. Conforme mencionamos, esse processo de transformação da lógica de consumo de moda foi observado na pesquisa de tendências de moda que realizamos e vem ocorrendo por meio de uma valorização crescente de aspectos como o ambiente e a rotina doméstica, dos laços familiares e de amizade, da saúde e bem estar, sempre muito associados a uma ideia de vida mais simples, porém sem abandonar o ritmo de um estilo de 
vida moderno. Nesta inovadora forma de ver o mundo, coexistem o novo e o velho, o lapidado e o rustico, o preciso e o impreciso, o leve e o denso, os ritmos acelerados e lentos, e assim se configura um novo paradigma: o complexo [do latim complexus: COM - "junto", mais PLECTARE, "tecer", "entrelaçar"], aquilo que é tecido junto. 


\section{REFERÊNCIAS BIBLIOGRÁFICAS}

ALVES, R. A descarta bilidade das mercadorias e pessoas: consumo, obsolescência e relacionamentos humanos. Revista SESC, São Paulo, n. Abril, 2013.

AMAZING DESIGN: Pablo Reinoso. Design you trust, 2013. Disponivel em: <http://designyoutrust.com/2013/07/amazing-design-pablo-reinoso/>. Acesso em: 26 julho 2013.

AMERICAN ASSOCIATION OF TEXTILE CHEMISTS AND COLORISTS - AATCC. AATCC Test Method 20-2011: Fiber Analysis: Qualitative. In: AATCC Technical Manual. Durham: [s.n.], 2012. p. 42-61.

ANDRADE, J. E. P. D.; CORREA, A. R.; SILVA, C. V. D. G. F. Polo de tecelagem plana de fibras artificiais e sintéticas da região de Americana. [S.I.]: [s.n.], 2001. Disponível em:http://www.bndes.gov.br/SiteBNDES/export/sites/default/bndes_pt/Galerias/Arquivos/ conhecimento/relato/rs2_gs2.pdf. Acesso em: 08 mai. 2006.

ASSOCIÇÃO BRASILEIRA DA INDÚSTRIA TÊXTIL E CONFECÇÕES - ABIT. Consumo industrial de fibras e filamentos - 1970 a 2012, 2013. Disponivel em: <http://www.abit.org.br/adm/Editor/Document/Consumo\%20Industrial\%20de\%20Fibras\%2 0e\%20Filamentos\%20\%20(1970\%20a\%202012).pdf>. Acesso em: 04 abril 2013.

AVELAR, S. Moda, globalização e novas técnologias. Rio de Janeiro: SENAC, 2009.

BONSIEPE, G. Design, cultura e sociedade. São Paulo: Blücher, 2011.

BORGES, A. Design + Artesanato: o caminho brasileiro. São Paulo: Terceiro Nome, 2011.

BRASIL. Decreto Federal no 6.040 de 7 de fevereiro de 2007. Institui a Política Nacional de Desenvolvimento Sustentável dos Povos e Comunidades Tradicionais. Brasília. 2007.

BÜRDEK, B. E. História, Teoria e Pática do Design de Produtos. São Paulo: Edgard Blücher, 2006.

CALDAS, D. Design e identidade no Brasil contemporâneo. In: CALDAS, D. O observatórios de sinais: Teoria e prática da pesquisa de tendências. Rio de Janeiro: Senac, 2004. p. 144-171.

CAMARGO, M. T. A. Etnofarmacobotânica: conceituação e metodologia de pesquisa. São Paulo: Humanitas/FFLCH/USP: Terceira Margem, 2003.

CARDOSO, R. Uma introdução à história do design. São Paulo: Edgard Blücher, 2010.

CENTRO NACIONAL DE DESENVOLVIMENTO SUSTENTADO DAS POPULAÇÕES TRADICIONAIS CNPT/IBAMA. Projeto de desenvolvimento sustentável com populações tradicionais, 2011. Disponivel

em: 
<http://www.pnud.org.br/administracao/reportagens/index.php?id01=2592\&lay=apu>. Acesso em: 21 maio 2012.

CHAUÍ, M. Mito fundador e sociedade autoritária. São Paulo: Fundação Perseu Abramo, 2000.

CLARK, H. Slow + Fashion: An oximoron or a promise for the future.? Fashion Theory, Berg, 12, n. 4, 2008. 427-446. Disponível em:. Acesso em: 14 mai. 2011.

DAMSCENO, S. M. B.; SILVA, F. T. F. D.; FRANCISCO, A. C. D. Sustentabilidade do processo de tingimento do tecido de algodão orgânico. ENCONTRO NACIONAL DE ENGENHARIA DE PRODUÇÃO, São Carlos, XXX, 2010. Disponível em: http://www.pg.utfpr.edu.br/dirppg/ppgep/ebook/2010/CONGRESSOS/ENEGEP/20.pdf. Acesso em: 18 janeiro 2012.

DUARTE, A. Y. S.; QUEIROZ, R. S. Etnobotânica de Fibras Naturais em Populações Tradicionais: Estudo das Espécies Bactris setosa e Daphynopsis fasciculata para Aplicação Têxtil. São Paulo: [s.n.], 2009. Trabalho de conclusão de curso (Bacharelado em Têxtil e Moda) - Escola de Artes, Ciências e Humanidades da Universidade de São Paulo.

DUARTE, C. R. A tecelagem manual no Triângulo Mineiro: história e cultura material. Uberlândia: EDUFU, 2009.

ERHARDT, T. et al. Curso técnico têxtil: Física e química aplicada - Fibras têxteis - Tecnologia. São Paulo: EPU, 1976.

EXPÓSITO, E. El diseño en las artesanías misioneras - Primera parte: Los textiles. Actas de Diseño, Buenos Aires, 7, 2009. 88-98. Disponível em: http://fido.palermo.edu/servicios_dyc/publicacionesdc/archivos/16_libro.pdf. Acesso em: 30 ago. 2009.

EXPÓSITO, E. El diseño en las artesanías misioneras - Segunda parte: La cestería. Actas de Diseño, Buenos Aires, 9, n. 2, 2010. 106-112. Disponível em: http://fido.palermo.edu/servicios_dyc/publicacionesdc/archivos/148_libro.pdf. Acesso em: 23 abr. 2011.

FERREIRA, E. Tingimento Vegetal: teoria e prática sobre tingimento com corantes naturais. [S.I.]: Comissão Pró-Índio de São Paulo, 2005. Disponivel em: www.cpisp.org.br/etnodesenvolvimento/img/futuros/cartilha_corante.pdf. Acesso em 25 março 2013.

FERREIRA, E. L. Corantes naturais da flora brasileira: guia prático de tingimento com plantas. Curitiba: Optagraf, 1998.

FILHA, D. C. M.; CORRÊA, A. BNDES 50 Anos - Histórias Setoriais: O Complexo Têxtil, [s.I], 2002. Disponivel em: 


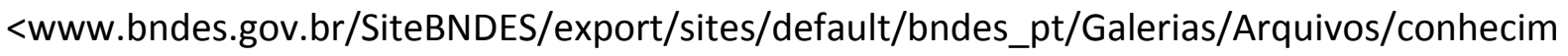
ento/livro_setorial/setorial11.pdf>. Acesso em: 28 junho 2013.

FINKIELSZTEJN, B. Sistemas Modulares Têxteis como aproveitamento de fibras naturais: Uma alternativa em Arquitetura \& Design. Rio de Janeiro: [s.n.], 2006. Dissertação (Mestrado em Artes) - Pontifícia Universidade Católica.

FINKLER, M. et al. Compósitos de HDPE com Resíduos de Fibras Têxteis. Parte I: Caracterização Mecânica. Polímeros: Ciência e Tecnologia, 15, n. 3, 2005. 171-175. Disponível em: http://www.scielo.br/pdf/po/v15n3/26480.pdf. Acesso em: 06 mai. 2006.

FLÁVIA Aranha. Flávia Aranha. Disponivel em: <http://www.flaviaaranha.com/FLAVIA_ARANHA/Flavia_Aranha_Biografia.html>. Acesso em: 13 junho 2013.

FLORA BRASILIENSIS. Chorisia speciosa - Prancha. Flora Brasiliensis - Obra, 1886. Disponivel em: <http://florabrasiliensis.cria.org.br/fviewer>. Acesso em: 17 fevereiro 2011.

FRINGS, G. S. Fashion: From Concept to Consumer. [S.I.]: Prentice-Hall , 2005.

GARCIA, M. M. Tecelagem artesanal: estudo etnográfico em Hidrolândia, Goiás. Goiânia. 1981.

GEISEL, A.; LODY, R. Artesanato brasileiro: Tecelagem. Rio de Janeiro. 1983.

GODDARD, J. 3 ways to arrage supermarket flowers. A cup of Jo, 2013. Disponivel em: <http://joannagoddard.blogspot.com.br/2013/02/3-ways-to-arrange-supermarketflowers.html\#more>. Acesso em: 05 abril 2013.

HAGEDORN, A. Festa em casa. Petiscos, 2010. Disponivel em: <http://juliapetit.com.br/home/festa-em-casa/>. Acesso em: 2013 maio 21.

HAGLER, J. thrown together. A Merry Mishap, 16 maio 2013. Disponivel em: <http://www.amerrymishapblog.com/2013/05/thrown-together_16.html>. Acesso em: 20 maio 2013.

HEIMBUCH, J. 15 Easy recipes for eating local and vegetarian in May. Treehugger, 2013. Disponivel em: <http://www.treehugger.com/easy-vegetarian-recipes/15-easy-recipeseating-local-and-vegetarian-may.html>. Acesso em: 21 maio 2013.

HIEMSTRA, G. The Sandwichbike: a flat-packed wooden bicycle delivered to your door for self assembly. Cool hunting, 2013. Disponivel em: <http://www.coolhunting.com/design/the-sandwichbike.php>. Acesso em: 21 maio 2013.

INSTITUTO DE RECURSOS MUNDIAIS - WRI; UNIÃO INTERNACIONAL PARA CONSERVAÇÃO DA NATUREZA - UICN; PROGRAMA DAS NAÇÕES UNIDAS PARA O MEIO AMBIENTE - 
PNUMA. A Estratégia global da biodiversidade: Diretrizes da ação para estudar, salvar e usar de maneira sustentável e justa a riqueza biótica da Terra. [S.I.]: Fundação O Boticário de Proteção à Natureza, 1992.

INTERNATIONAL COUNCIL OF SOCIETIES OF INDUSTRIAL DESIGN - ICSID. About ICSID. Definition of Design. Disponivel em: <http://www.icsid.org/about/about/articles31.htm>. Acesso em: 10 abril 2013.

KOOISTRA, K.; PYBURN, R.; TERMORSHUIZEN, A. The sustainability of cotton: Consequences for man and environment. Science Shop Wageningen University \& Research Centre, n. 223, 2006. Disponível em: http://www.wageningenur.nl/upload/6cdf8347-b399-4365-8459e24aeaba6922_223.pdf. Acesso em: 05 fevereiro 2013.

KUBRUSLY, M. E.; IMBROISI, R. Desenho de fibra: artesanato têxtil no Brasil. Rio de Janeiro: SENAC, 2011.

LEÃO, J. Os "Bureaux de Style" e sua ótica sobre a produção de moda. In: WAJNMAN, S.; ALMEIDA, A. J. D. Moda , Comunicação e Cultura: Um Olhar Acadêmico. São Paulo: Arte \& Ciência; NIDEM - Núcleo Interdisciplinar de Estudos da Moda/UNIP; Fapesp, 2002.

LÉVI STRAUSS, C. O uso de plantas silvestres da América do Sul Tropical. In: RIBEIRO, B. G. Suma: Etinologia Brasileira - Etnobiologia. Petrópolis: Vozes, 1987.

LIPOVETSKY, G. O império do efêmero: a moda e seus destinos na sociedade maderna. São Paulo: Companhia das Letras, 1994.

LITTLE, P. E. Territórios sociais e povos tradicionais do Brasil: por uma antropologia da territorialidade. Série antropologia, Brasília, n. 322, 2002. Disponível em: http://www.dan.unb.br/images/doc/Serie322empdf.pdf. Acesso em: 30 mai. 2012.

LORENZI, H. Árvores Brasileira: Manual de identificação e cultivo de plantas arbóreas nativas do Brasil. São Paulo: Plantarum, v. 1 e 2, 1998.

MEDINA, J. C. Plantas Fibrosas da Flora Mundial. Campinas: Instituto Agronômico de Campinas, 1959.

MOREAL, X.; FONSECA, M. C. L.; ALTAFIN, G. Tecelagem manual no Triângulo Mineiro: uma abordagem tecnológica. Brasília: Fundação Nacional Pró-Memória - IPHAN, 1984.

MORIN, E. Introdução ao Pensamento Complexo. Porto Alegre: Sulina, 2005.

O veneno está na mesa. [S.I.]: Copyrigth Caliban. 2011. Disponível em: http://www.youtube.com/watch?v=8RVAgD44AGg. Acesso em: 13 janeiro 2012.

OLIVEIRA, M. H. Princiapais Matérias-Primas Utilizadas na Indústria Têxtil. BNDES Setorial, Rio de Janeiro, n. 5, março 1997. 1-40. 
ON THE STREET. IPANEMA BEACH, RIO DE JANEIRO. The sartorialist, 2013. Disponivel em: $<$ http://www.thesartorialist.com/photos/on-the-street-ipanema-beach-rio-de-janeiro/>. Acesso em: 2013 maio 21.

ORGANIZAÇÃO DAS NAÇÕES UINDAS PARA AGRICULTURA E ALIMENTAÇÃO - FAO. Notícias. Comienza el Año Internacional de las Fibras Naturales: 2009 dedicado a las fibras procedentes de animales y vegetales. Site Oficial da Organização das Nações Uindas para Agricultura e Alimentação - FAO, 2009. Acesso em: 23 outubro 2009.

PALEVECINO, D. M. Arte del Tejido em la Argentina. Buenos Aires: Ediciones Culturales Argentinas, 1981.

PEREIRA, O. J. et al. A gestão organizacional no setor têxtil: Limites e desafios diante dos novos paradigmas da aldeia global. [S.I.]: [s.n.], 2003.

PIO CORRÊA, M. Dicionário de plantas úteis do Brasil e das exóticas cultivadas. Rio de Janeiro: IBDF, v. I a VI, 1984.

POSEY, D. Introdução - Etnobiologia: Teoria e Prática. In: RIBEIRO, B. G. Suma Etnológica Brasileira: Etnobiologia. Petrópolis: Vozes, v. 1, 1987.

POSEY, D. Introdução - Manejo da Floresta Secundária, Capoeiras, Campos e Cerrados (Kayapó). In: RIBEIRO, B. G. Suma Etnológica Brasileira: Etnobiologia. Petrópolis: Vozes, v. 1, 1987.

RENDAS e Bordados. ArteSol - Artesanato Solidário. Disponivel em: <http://www.artesol.org.br/site/rendas-e-bordados/>. Acesso em: 14 abril 2012.

REVISTA Casa e Comida. Capa. Revista Casa e Comida, São Paulo, n. 18, setembro/outubro 2012.

REVISTA Vida Simples. Capa, São Paulo, n. Edição Especial 6, 2012.

RIBEIRO, L. G. Introdução à Tecnologia Têxtil. Rio de Janeiro: SENAI/CETIQT, v. I, II e III, 1984.

SALAZAR, V. L. P.; CARASCHILL, J. C.; LEÃO, A. L. Avaliação dos produtos de emissão a partir de pirólise de assentos automotivos feitos de fibra de coco e de espuma de poliuretano. Engenharia Sanitária e Ambiental, 10, n. 2, 2005. Disponível em: http://www.scielo.br/pdf/esa/v10n2/a10v10n2.pdf. Acesso em: 06 mai. 2006.

SANTIAGO, M. Manifesto por um Etnodesign. Para ler e pensar, 22 março 2010. Disponivel em: <http://paralerepensar.blogspot.com.br/2010/03/manifesto-por-um-etnodesign.html>. Acesso em: 26 janeiro 2012.

SARMENTO, J. Etnodesign e cultura brasileira: memória, resgate e identidade. II Seminário Internacional: fronteiras étnico-culturais - fronteiras da exclusão (Práticas educativas num 
contexto intercultural), 2006. Disponivel em: <www.neppi.org/gera_anexo.php?id=514>. Acesso em: 16 novembro 2010.

SCHUMACHER, E. F. Small is Beautiful: Um estudo de economia em que as pessoas também contam. Lisboa: Dom Quixote, 1972.

SOM ECOLÓGICO. Petiscos, 2013. Disponivel em: <http://juliapetit.com.br/casa/somecologico/>. Acesso em: 04 março 2013.

TARANTO, E.; MARI, J. Textiles Argentinos. Buenos Aires: Maizal, 2003.

TECELAGEM e fiação. ArteSol - Aresanato Solidário. Disponivel em: <http://www.artesol.org.br/site/tecelagem-e-fiacao/>. Acesso em: 14 abril 2012.

TEXTILE VIEW MAGAZINE. Knits and Yarns. Summer 2014, Amsterdan, n. 100, 2012.

TEXTILE VIEW MAGAZINE. Fibres \& Fabrics. Crafts and Sustainability, Amsterdan, n. 101, 2013.

TOP Sites. The top ranked sites in each category. All categories $>$ Arts $>$ Design $>$ Weblogs. Alexa - The Web Information Company. Disponivel em: <http://www.alexa.com/topsites/category/Top/Arts/Design/Weblogs>. Acesso em: 28 abril 2013.

UNIÃO INTERNACIONAL PARA A CONSERVAÇÃO DA NATUREZA E DOS RECURSOS NATURAIS UICN; PROGRAMA DAS NAÇÕES UNIDAS PARA O MEIO AMBIENTE - PNUMA; FUNDO MUNDIAL PARA A NATUREZA - WWF. Cuidando do Planeta Terra: Uma Estratégia para o Futuro da Vida. São Paulo: CL-A Cultural, 1992.

UNIÃO INTERNACIONAL PARA CONSERVAÇÃO DA NATUREZA - UICN. Estratégia Mundial para a Conservação: a conservação dos recursos vivos para um desenvolvimento sustentado. São Paulo. 1984.

VICENT-RICARD, F. Do artesanato à informática e à robótica. um rítimo milenar. In: VICENTRICARD, F. As espeirais da moda. Rio de Janeiro: Paz e Terra, 1989.

VICENT-RICARD, F. O estilo industrial. In: VICENT-RICARD, F. As espirais da moda. Rio de Janeiro: Paz e Terra, 1989.

APÊNDICE A - Caderno de coleção 


\section{c a d e rno da col e ção}

a natureza no concreto 
Na paisagem predominantemente urbana das grandes cidades, o que num passado muito distante o concreto viria a ser uma intervenção do homem na natureza, hoje é ela que se manifesta como uma invasora.

As manifestações espontâneas da natureza no concreto, que vão além daquilo que é controlado e desejado pelo homem (como por exemplo, os jardins), são o tema dessa coleção.

Ao observamos essas intervenções espontâneas da natureza, desvendamos uma linguagem que vai ao encontro das tendências que apresentamos no capitulo anterior. O concreto é o elemento que hoje divide dois ritmos, dois planos que coexistem: acima dele: o fluxo, o movimento, a velocidade e a superficialidade, viabilizados pelas tecnologias e o agito da vida urbana e abaixo dele: um ritmo denso, profundo e lento, representado pela terra, raízes e plantas. Este último, por muito tempo oculto e reprimido pela lógica urbana, emerge do solo e permeia a barreira rígida do concreto, aludindo à imposição, ou sobreposição, de uma "nova" lógica.

Essa natureza que "nasce" no concreto, representa a emergência dos movimentos lentos, do resgate à memória ancestral, à essência, daquilo que é "puro e inalterado" (TEXTILE VIEW MAGAZINE, 2012) e sua associação ao ritmo urbano. 

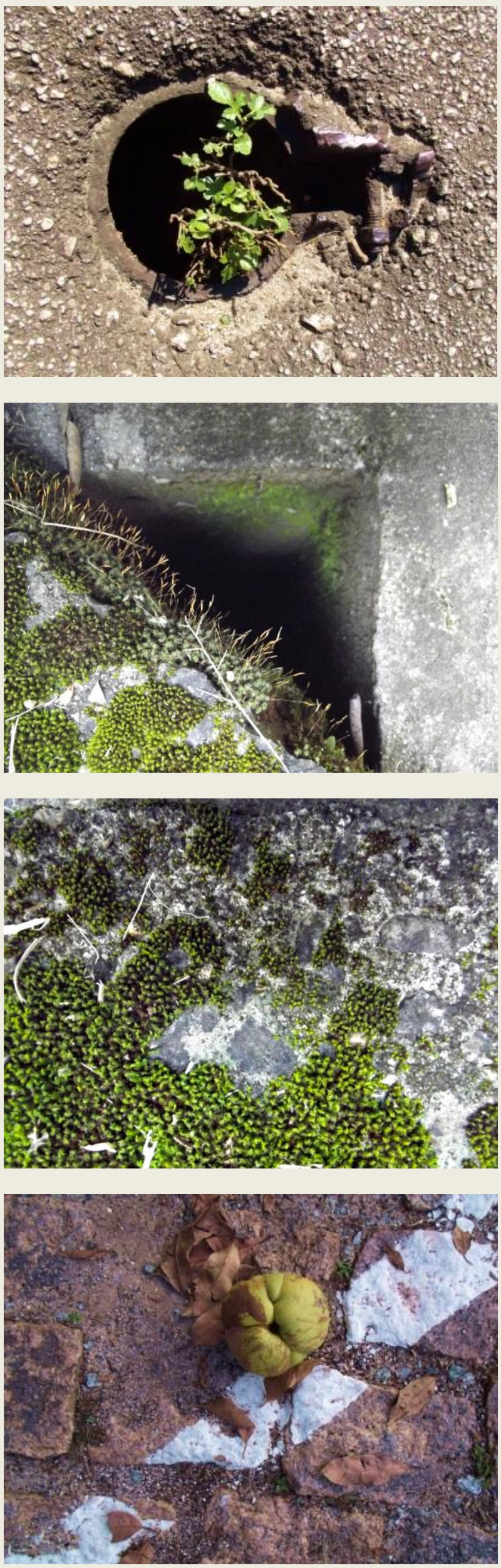

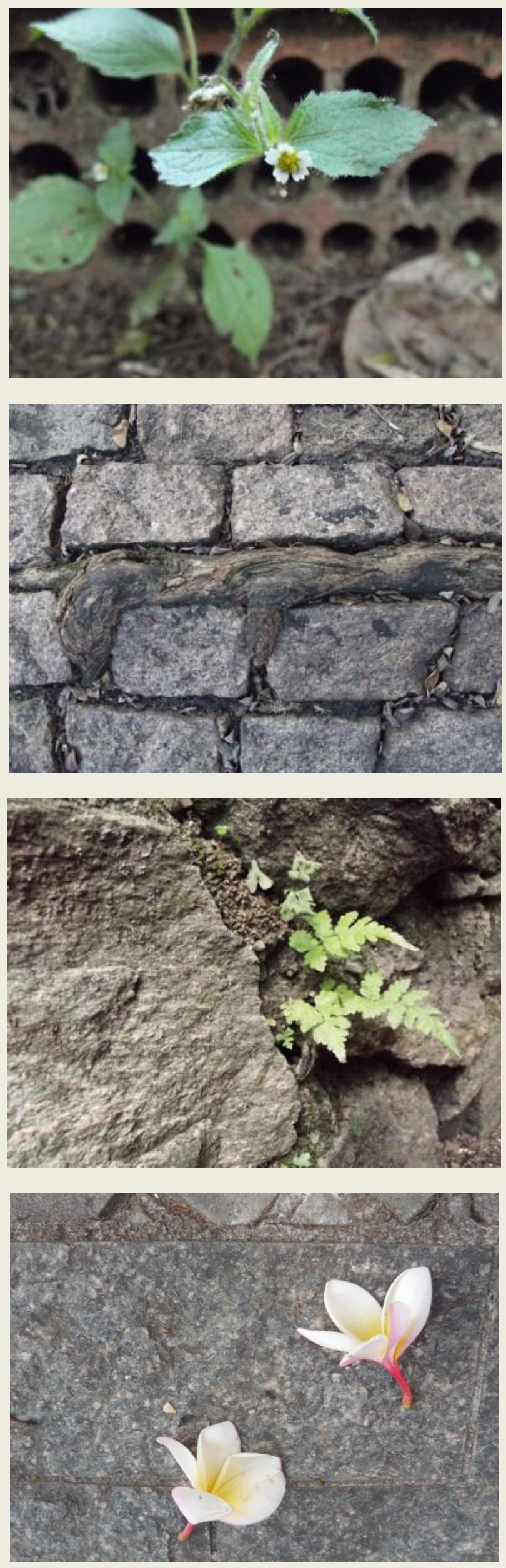
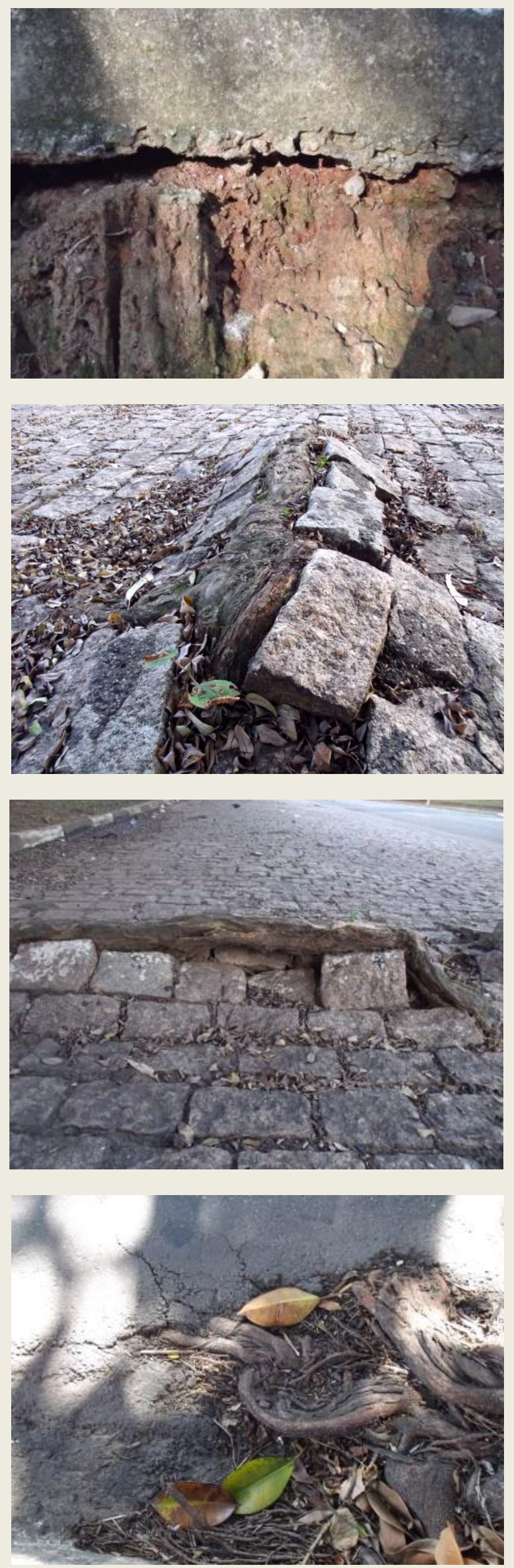


\section{cores}

\section{PANTONE 18-1321 TPX}

Brownie

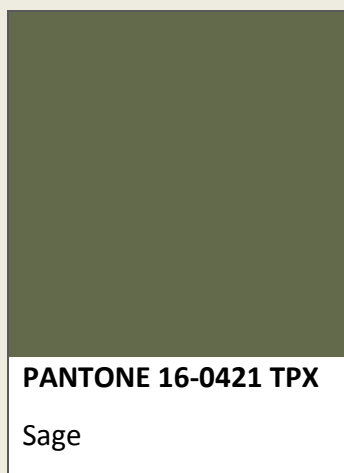

PANTONE 14-0827 TPX Dusky Citron
PANTONE 19-0512 TPX

Ivy Green
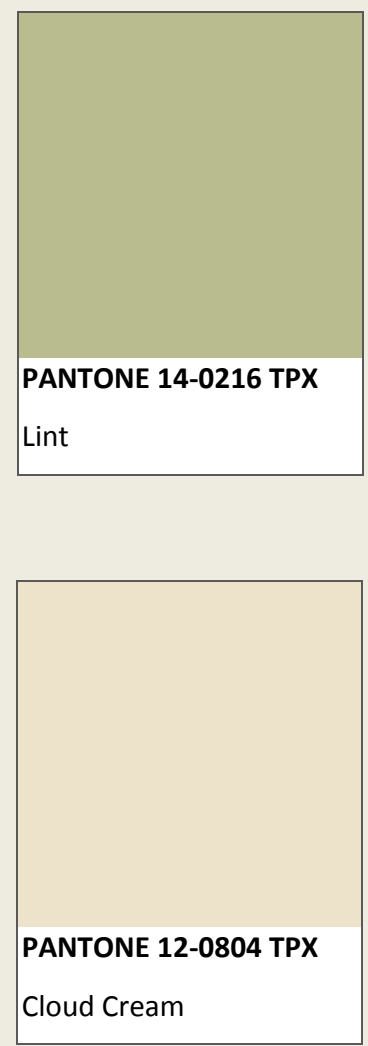


\section{fios}

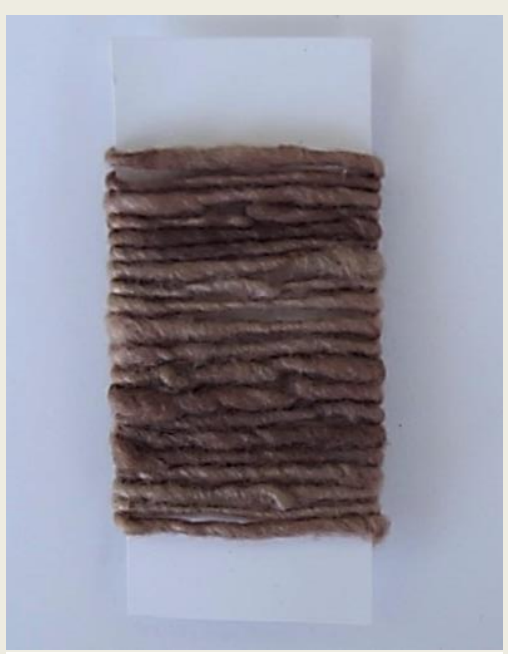

Composição: alma de algodão revestida de paina

Tingimento: mate (torrado) e barbatimão em panela de ferro

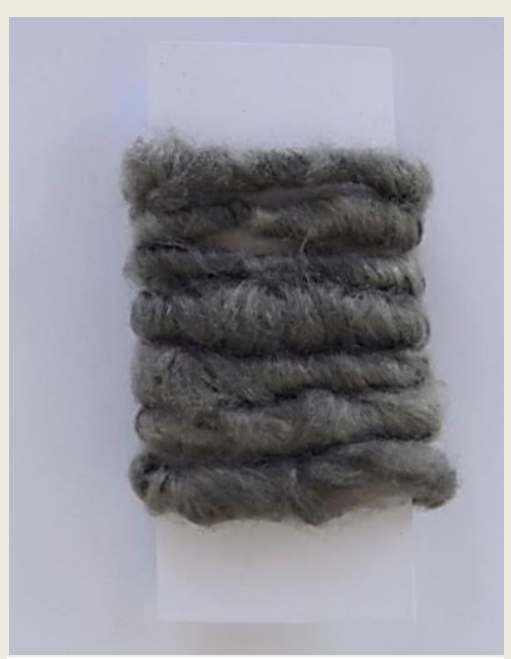

Composição: paina e algodão

Tingimento: erva-mate em panela de ferro

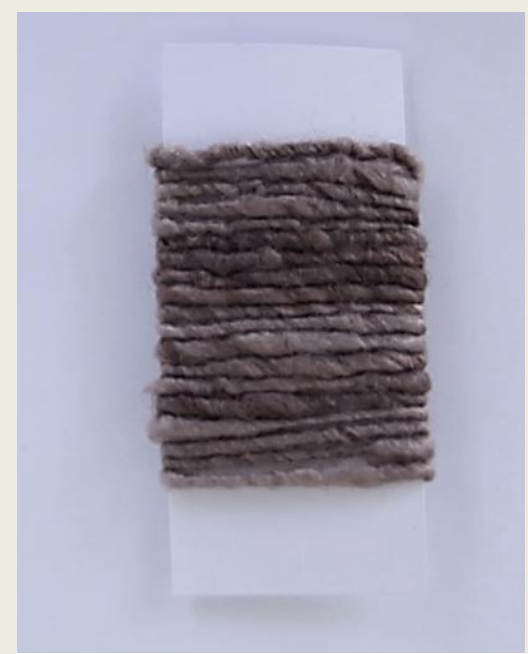

Composição: paina e lã

Tingimento: mate (torrado) e barbatimão em panela de cobre

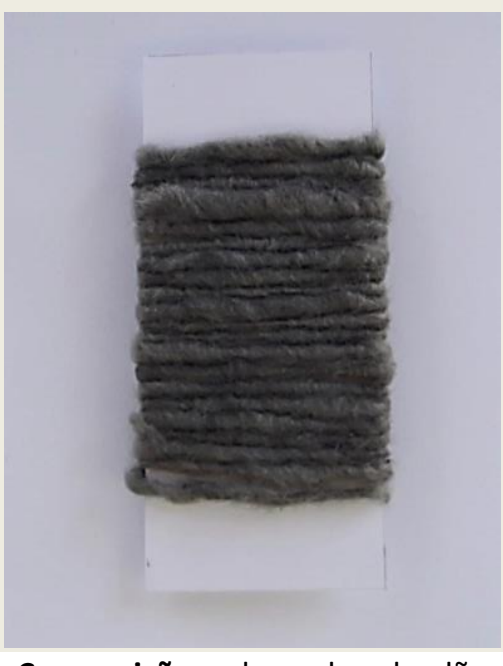

Composição: alma de algodão revestida de paina

Tingimento: erva-mate em panela de ferro 


\section{fios}

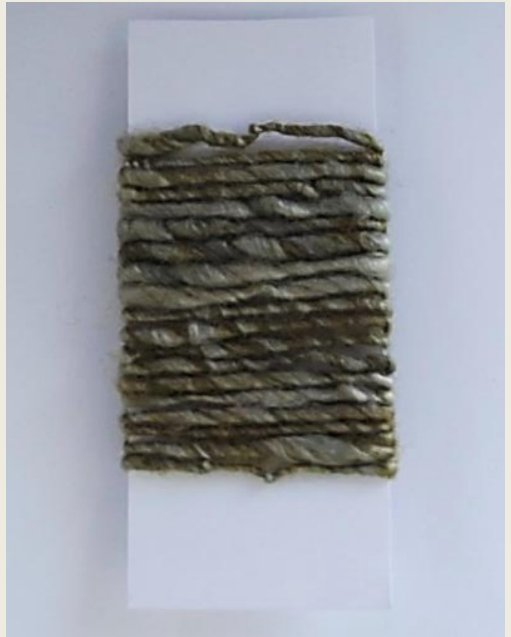

Composição: paina e lã

Tingimento: erva-mate em panela de cobre

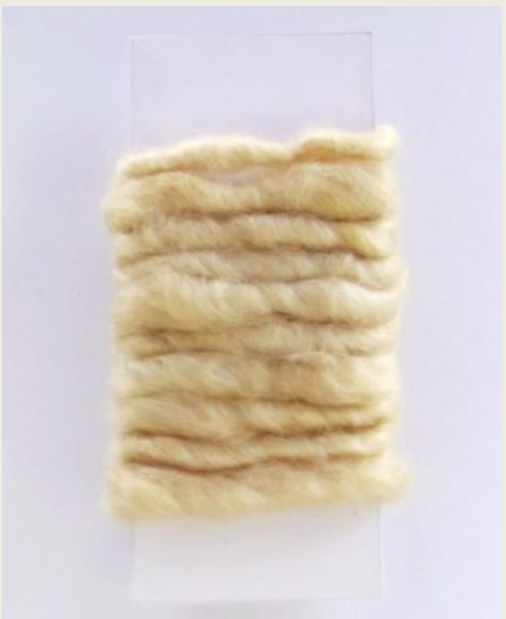

Composição: paina e algodão

Tingimento: casca de manga em panela de alumínio

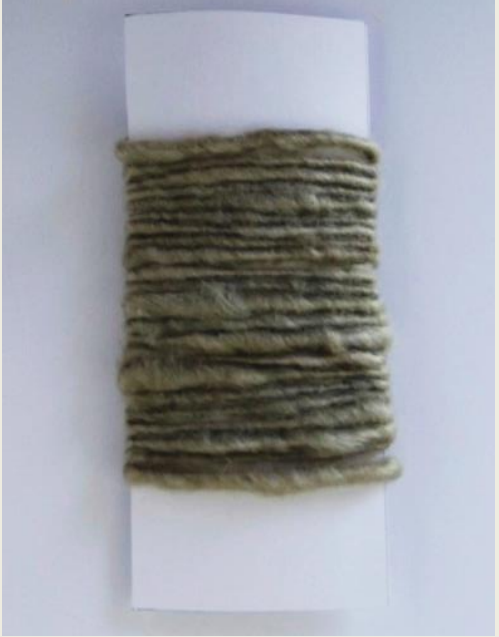

Composição: paina e algodão

Tingimento: erva-mate em panela de cobre

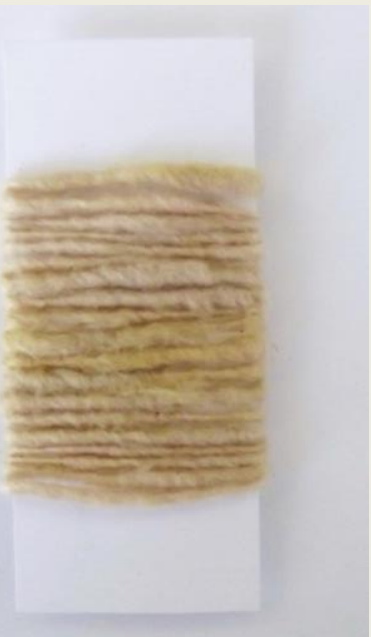

Composição: alma de algodão revestida de paina

Tingimento: espinafre em panela de alumínio 


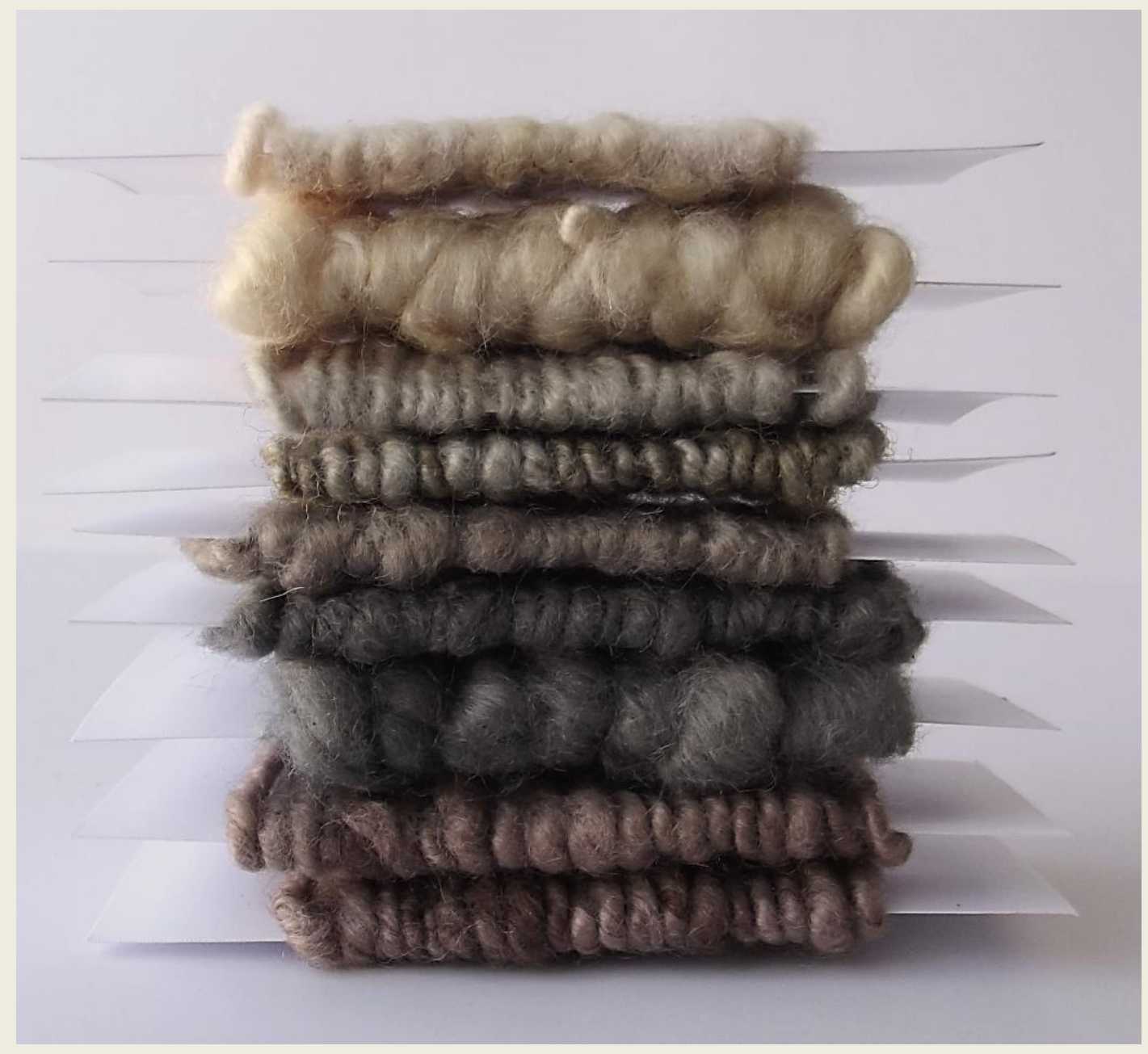

